ROSA MARIA DE FREITAS ROGERIO

\title{
Caminhos de Professoras: o desenvolvimento profissional docente nos anos iniciais do Ensino Fundamental.
}


e-mail para contato: rosarogerio@yahoo.com.br 


\section{Caminhos de Professoras: o desenvolvimento profissional docente nos anos iniciais do Ensino Fundamental.}

Dissertação apresentada como exigência parcial para obtenção do Título de Mestre em Educação, junto ao Programa de PósGraduação em Educação na área de Didática, Teorias do Ensino e Práticas Escolares da Faculdade de Educação da Universidade de São Paulo, sob orientação da Profa. Dra. Maria Isabel de Almeida.

São Paulo - 2008 
Autorizo a reprodução e divulgação total ou parcial deste trabalho, por qualquer meio convencional ou eletrônico, para fins de estudo e pesquisa, desde que citada a fonte.

Catalogação na Publicação

Serviço de Biblioteca e Documentação

Faculdade de Educação da Universidade de São Paulo

371.124(81.61) Rogério, Rosa Maria de Freitas

R723c Caminhos de professoras : o desenvolvimento profissional docente nos anos iniciais do ensino fundamental / Rosa Maria de Freitas Rogério ; orientação Maria Isabel de Almeida. São Paulo: s.n., 2008.

195 p. : il, tabs.

Dissertação (Mestrado - Programa de Pós-Graduação em Educação. Área de Concentração: Didática, Teorias do Ensino e Praticas Escolares) - - Faculdade de Educação da Universidade de São Paulo.

1. Professores de ensino fundamental - Formação profissional - São Paulo, SP 2. Desenvolvimento profissional 3. História oral I. Almeida, Maria Isabel, orient. 


\section{UNIVERSIDADE DE SÃO PAULO \\ FACULDADE DE EDUCAÇÃO \\ PROGRAMA DE PÓS-GRADUAÇÃO EM EDUCAÇÃO DIDATICA, TEORIAS DO ENSINO E PRÁTICAS ESCOLARES}

Autora: ROGERIO, Rosa Maria de Freitas

Título: Caminhos de professoras: o desenvolvimento profissional docente nos anos iniciais do Ensino Fundamental.

Orientadora: Profa. Dra. Maria Isabel de Almeida

\section{Dissertação de Mestrado em Educação}

Este exemplar corresponde à redação final da Dissertação de Mestrado em Educação de Rosa Maria de Freitas Rogério submetida à Comissão de Pós-Graduação da Faculdade de Educação da USP para obtenção do Título de Mestre em Educação, na Linha de Pesquisa: Didática, Teorias do Ensino e Práticas Escolares tendo sido aprovada em ____/2008, pela seguinte Banca Examinadora:

\section{BANCA EXAMINADORA}

Profa. Dra. Maria Isabel de Almeida

Profa. Dra. Paula Perin Vicentini

Profa. Dra. Marineide de Oliveira Gomes 
Dedico essa dissertação a todos os professores que acreditam na grandeza de seu trabalfo e que ajudam a construir uma escola pública de qualidade. 


\section{$\underline{\text { AgRadeÇO }}$}

$\grave{A}$ Bel

- pela orientação cuidadosa e generosa na Iniciação Científica e no Mestrado;

- pelas aulas inesquecíveis no curso de Didática em 2002;

- pela atenção e carinho quando me vi envolvida em situações difíceis na FEUSP e na profissão de professora;

- pela agradável companhia nesses quase seis anos de convivência;

- pelo aprendizado. Sentirei saudades.

À Faculdade de Educação da USP

- pela possibilidade de realização do mestrado;

Aos funcionários da FEUSP

- pela atenção generosa;

- pelo trabalho competente e dedicado.

\section{Ao GEPEFE}

- pelas valiosas contribuições à minha formação como pesquisadora;

- pelas importantes discussões sobre o universo da escola e da profissão de professor;

- pela rica convivência com pesquisadores de todo o Brasil.

À Secretaria Estadual de Educação

- pela concessão da Bolsa Mestrado durante o tempo em que fui professora desta rede.

$\mathcal{A} s$ professoras Paula Perin Vicentini e Marineide de Oliveira Gomes

- pelas contribuições fundamentais no Exame de Qualificação;

- pela aceitação do convite para participar da Banca de Defesa do Mestrado.

À Tânia, professora e amiga,

- pelas deliciosas conversas sobre a profissão de professor. 
$\mathcal{A}$ Marilza, professora e amiga,

- pela parceria no trabalho na escola;

- pelas contribuições para minha formação como professora;

- por acreditar que nós professores podemos fazer a diferença;

- pela companhia na construção de uma escola pública de qualidade.

À Rosa Helena, irmã gêmea, professora e amiga,

- pela parceria em toda a vida desde os tempos de estudante até os tempos de professora;

- pela companhia e pelo apoio em nossos tempos de graduação na FFLCH;

- pelas contribuições que fez ao texto final dessa dissertação.

Às queridas professoras Margareth, Estela e Isabela

- pela imprescindível colaboração com essa dissertação;

- pela disponibilidade em participar da pesquisa;

- pelas generosas contribuições sobre o desenvolvimento profissional de professoras dos anos iniciais do Ensino Fundamental.

Aos meus pais, Geralda e Sérgio,

- pelo apoio incondicional aos meus estudos;

- pelo carinho e pelo cuidado atencioso;

- por torcer para que eu seja uma professora melhor a cada dia.

À Deus

- pela oportunidade de aprendizado em mais uma vida. 


\section{ROGÉRIO, Rosa Maria de Freitas. Caminhos de professoras: o desenvolvimento}

profissional docente nos anos iniciais do Ensino Fundamental. São Paulo: Faculdade

de Educação da Universidade de São Paulo, 2008. (Dissertação de Mestrado)

\section{RESUMO}

Este é um estudo sobre como professoras dos anos iniciais do Ensino Fundamental se desenvolvem profissionalmente e produzem sua profissão. Buscamos compreender de que forma o desenvolvimento profissional de professoras é influenciado pela experiência e pelas vivências de cada uma delas na trajetória da carreira. Para compreendermos esse desenvolvimento, adotamos como referência a Rede Municipal de Ensino de São Paulo porque essa apresenta elementos importantes para nosso estudo como, por exemplo, a existência de um estatuto que legitima a profissão docente e que proporciona para os professores oportunidades de desenvolvimento profissional dentro da sua jornada de trabalho. Para responder aos objetivos propostos pela pesquisa, convidamos três professoras da Rede Municipal de Ensino com diferentes anos de experiência docente e que estavam atuando nos anos iniciais do Ensino Fundamental em 2006. Na tentativa de captar o relato das experiências vividas pelas professoras buscou-se o apoio da História Oral porque esta permite apreender a experiência vivida por determinados indivíduos (três professoras) num contexto macro social (profissão docente). Buscamos também os estudos sobre a carreira do professor, de modo a refletir sobre o seu percurso profissional e compreender como ocorre o processo de desenvolvimento profissional. Os estudos sobre a profissão docente tiveram como base as contribuições do português António Nóvoa (1986, 1991, 1995a, 1995b, 1998, 1999 e 2000) e das brasileiras Tanuri (1969 e 1979), Dias (2002), Marcílio (2005) e Castro (2005). Sobre o conceito de desenvolvimento profissional, buscamos apoio em Nóvoa (1995a e 2000), Marcelo Garcia (1994), Almeida (1999a, 1999b, 2004a, e 2004b), Souza (2005) e Day (1999). A hipótese orientadora desse estudo consistiu em considerar que o percurso do desenvolvimento profissional, que aparece no relato das professoras, ajuda a compreender os modos de ser professor na escola pública contemporânea. Elaboramos três categorias que nos orientaram no momento da análise dos dados: relação com o conhecimento, formação contínua e autonomia. Ao final da pesquisa, chegamos ao entendimento de que ao longo dos anos da carreira o professor vai se desenvolvendo profissionalmente, vai refletindo sobre seu modo de ser e de estar na profissão e vai criando e modificando sua ação pedagógica.

Palavras-chave: Desenvolvimento Profissional de Professores, Profissão Docente, Professoras dos anos iniciais do Ensino Fundamental, História Oral, Ciclos de Aprendizagem. 


\begin{abstract}
This is a study about how teachers of the initial years of the Basic Education are developing themselves professionally and how they are producing their profession. We search to understand how professional development of teachers is influenced by the experiences of each one of them during the career's trajectory. In order to understand this development, we adopt as reference the São Paulo's Municipal Education Net because it presents important elements four our study as, for example, the existence of a statute that legitimizes the teaching profession and that provides for the teachers opportunities of professional development inside their days' work. To answer to the objectives considered for the research, we invite three teachers of the Municipal Education Net with different years of experience. These teachers were teaching to the initial years of Basic Education in 2006. In the attempt to catch the story of the experiences lived by the teachers, we search the Oral History's support because this allows us to apprehend the person's lived experience (three teachers) inside the social context (teaching profession). We also search teacher's career studies in order to reflect about its professional trajectory and to understand how the process of professional development occurs. The teaching profession's studies have been supported by the contributions of Portuguese António Nóvoa (1986, 1991, 1995a, 1995b, 1998, 1999 e 2000) and by the contributions of Brazilians Tanuri (1969 e 1979), Dias (2002), Marcílio (2005) and Castro (2005). The professional development's concept has been supported by the contributions of Nóvoa (1995a and 2000), Marcelo Garcia (1994), Almeida (1999a, 1999b, 2004a and 2004b), Souza (2005) and Day (1999). The hypothesis that guides this study consists of considering the professional development, that is in the teachers' stories, as a help to understand the ways of being teacher in the contemporary public school. We elaborate three categories that have guided us during the data's analysis: relation with the knowledge, continuous formation and autonomy. To the end of the research, we reach the agreement that along the career's years the teacher have been developing itself professionally, have been reflecting about its ways of being in the profession and have been creating and modifying its pedagogic action.
\end{abstract}

Key words: Teacher's Professional Development, Teaching Profession, Teachers of the Basic Education initial years, Oral History, Learning Cycles. 


\section{$\dot{I}_{\text {NDICE }}$}

Resumo

Abstract _ 13

Introdução _ 21

Capítulo I - A Construção da Pesquisa___ 31

1 - Justificativa___ 33

1.1. Profissão docente e desenvolvimento profissional ___ 33

1.2. A carreira do magistério ___ 38

1.3. As professoras da Rede Municipal de Ensino de São Paulo __ 49

2 - O Referencial Teórico __ 50

2.1. História Oral ___ 51

2.2. Percurso Profissional: a carreira vista a partir da história de vida __ 54

3 - O Caminho Metodológico __ 57

Capítulo II - A Rede Municipal de Ensino de São Paulo __ 61

1 - Origem da Rede Municipal de Ensino __ 63

2 - Os Ciclos e a Rede Municipal de Ensino de São Paulo ___ 68

3 - Os Ciclos e as professoras: quais demandas são colocadas para o trabalho

docente? _ 75

Capítulo III - A Profissão Docente e o Desenvolvimento Profissional ___ 85

1 - A profissão docente em foco

2 - O desenvolvimento profissional em questão ___ 103

Capítulo IV - Modos de Desenvolvimento Profissional na Escola Municipal__ 115

1 - Formação inicial ___ 117

2 - Percurso Profissional __ 119

2.1. Professora Margareth - 23 anos de docência ___ 120 
2.2. Professora Estela - 14 anos de docência

2.3. Professora Isabela - 3 anos de docência

3 - Desenvolvimento Profissional

3.1. Relação com o conhecimento 132

3.2. Formação contínua 146

3.3. Autonomia 159

Considerações Finais 173

Bibliografia 181

Anexos 191

ANEXO 1 - Roteiro para entrevista com professoras ( $2^{\circ}$ semestre de 2006) 193 ANEXO 2 - Roteiro para Entrevista Recorrente ( $1^{\circ}$ semestre de 2007$)$ 195 


\section{Índice de Tabelas}

TABELA 1 - Jornada de Trabalho Docente 44

TABELA 2 - Tabela de Vencimentos Jornada Básica 46

TABELA 3 - Tabela de Vencimentos Jornada Especial Ampliada 47

TABELA 4 - Tabela de Vencimentos Jornada Especial Integral 47

TABELA 5 - Fases da Carreira Segundo Huberman (2000, p. 47) 56

TABELA 6- Situação dos Professores - Rede Municipal de Ensino de São Paulo 67

TABELA 7 - Regimes de Ensino Não Seriados 73

TABELA 8 - Formação Inicial e Atuação Profissional 117

TABELA 9 - Percurso Profissional: Professora Margareth 120

TABELA 10 - Percurso Profissional : Professora Estela 125

TABELA 11 - Percurso Profissional : Professora Isabela 129 


\title{
Lista de Siglas
}

\author{
ACT Professor Admitido em Caráter Temporário \\ ATP Assistente Técnico Pedagógico \\ CBA Ciclo Básico de Alfabetização \\ CBC Ciclo Básico Complementar \\ CBI Ciclo Básico Inicial \\ CECI Centro de Educação e Cultura Indígena \\ CEFAM Centro Específico de Formação e Aperfeiçoamento do Magistério \\ CEI Centro de Educação Infantil \\ CENP Coordenadoria de Estudos e Normas Pedagógicas SEE/SP \\ CEU Centro Educacional Unificado \\ CIEJA Centro de Integração da Educação de Jovens e Adultos \\ DEM Democratas (partido) \\ EMEF Escola Municipal de Ensino Fundamental \\ EMEFM Escola Municipal de Ensino Fundamental e Médio \\ EMEI Escola Municipal de Educação Infantil \\ FEUSP Faculdade de Educação da Universidade de São Paulo \\ GEPEFE Grupo de Estudos e Pesquisas sobre Formação de Educador \\ HEM Habilitação Específica para o Magistério \\ IIPE Instituto Internacional de Planeamiento de La Educación \\ JB Jornada Básica \\ JEA Jornada Especial Ampliada \\ JEI Jornada Especial Integral \\ LDB Lei de Diretrizes e Bases da Educação \\ OFA Ocupante de Função Atividade (professor eventual) \\ PCN Parâmetros Curriculares Nacionais \\ PDI Professor de Desenvolvimento Infantil \\ PIC Programa Intensivo de Ciclo \\ POIE Professor Orientador de Informático Educativa \\ POSL Professor Orientador de Sala de Leitura \\ PROFA Programa de Formação de Professores Alfabetizadores
}


PT Partido dos Trabalhadores

SEE Secretaria Estadual de Educação

SME Secretaria Municipal de Educação

TOF Toda Força ao Primeiro Ano do Ciclo I

UNESCO Organização das Nações Unidas para a Educação, a Ciência e a Cultura USP Universidade de São Paulo 
$\underline{\text { INTRODUCÃ̃ }}$ 
A forma como cada um de nós constrói a sua identidade profissional define modos distintos de ser professor, marcados pela definição de ideais educativos próprios, pela adoção de métodos e práticas que colam melhor com a nossa maneira de ser e pela escolha de estilos pessoais de reflexão sobre a ação.

Antonio Nóvoa

Um começo de conversa pressupõe a apresentação de quem se propõe a falar. Então vamos a essa apresentação. Sou Professora de Desenvolvimento Infantil da Rede Municipal de Ensino de São Paulo, fui Professora de Educação Básica I da Rede Estadual de Ensino de São Paulo e também lecionei História, em 2004, para alunos do terceiro ano do ensino médio num projeto desenvolvido pela Universidade de São Paulo em parceria com a Secretaria Estadual de Educação, que se chamava Pró-Universitário. Eu decidi que seria professora no final da oitava série, quando fiz minha matrícula para o curso de Magistério. Toda a minha trajetória como aluna se deu no sistema público de ensino de São Paulo: o primeiro grau e o curso de Magistério em Escolas Estaduais; a graduação em História e o mestrado em Educação na Universidade de São Paulo.

O curso de Magistério foi o meu primeiro contato, mesmo que de forma sintética, com as estruturas e funcionamento da escola pública. Esse curso levou-me a perceber que havia muitas incongruências no funcionamento da escola, na organização do trabalho docente, na constituição da jornada de trabalho do professor, na remuneração dos profissionais de educação, no modo como o currículo era pensando dentro das instituições educativas (secretarias, coordenadorias, diretorias de educação), etc. Essas incongruências mostraram que várias questões da escola pública precisavam ser repensadas. Dentre estas, a que se destacou como mais significativa foi a questão da profissão docente, porque o curso de Magistério caracterizava-se como um curso de formação inicial de professores e tinha como principais objetivos apresentar a profissão de professor e preparar o aluno para o ingresso no trabalho com crianças da educação infantil e dos quatro anos iniciais do Ensino Fundamental.

Mesmo havendo o interesse em refletir mais profundamente sobre a profissão docente, escolhi fazer a faculdade de História porque eu queria ser professora dessa disciplina. Durante a graduação, especialmente no curso de licenciatura, a oportunidade de ter a profissão docente como objeto de estudo colocou-se como realidade. As disciplinas Introdução aos Estudos da Educação e Didática da grade 
curricular de licenciatura da FEUSP foram responsáveis por promoverem valiosos debates sobre o trabalho do professor na escola pública.

Meu primeiro contato com a pesquisa em educação nasceu no momento em que cursei uma disciplina optativa no Instituto de Psicologia da USP. A disciplina em questão era Psicologia Escolar e Problemas de Aprendizagem I, que é parte obrigatória do currículo do curso de Psicologia e parte optativa livre do currículo do curso de História. Nesta disciplina, desenvolvi uma pesquisa sobre qual era o papel do professor dentro do processo educacional, cujo objetivo era entender de que forma(s) os professores se viam implicados nesse processo. Seus resultados me possibilitaram elaborar a seguinte hipótese: o professor se implica e se des-implica porque sua função não apresenta claramente os limites de sua atuação.

Estimulada pelas percepções e novas questões desenvolvidas nesse trabalho, busquei na Faculdade de Educação da USP espaço através de uma pesquisa de Iniciação Científica, sob orientação da Professora Doutora Maria Isabel de Almeida, realizada em uma Escola Municipal de Ensino Fundamental, entre abril de 2003 e setembro de 2004, para continuar investigando aspectos do dia-a-dia dos professores. O desenvolvimento dessa Iniciação Científica, que versou sobre o papel do professor na escola pública, pôde ser realizado junto ao projeto A reconstrução da profissionalidade docente no contexto da organização do ensino em ciclos, coordenado pela professora doutora Maria Isabel de Almeida.

No desenrolar das atividades desta Iniciação Científica, verifiquei junto aos professores que estes tinham clareza de que seu papel no processo educacional escolar mudou e/ou estava mudando e que atualmente eles têm muito mais obrigações e responsabilidades que antes, sendo que muitas das exigências que lhes são feitas são encaradas como funções que não lhes cabem, como, por exemplo, assumir o papel de assistente social, psicólogo, juiz, pai, mãe...

Segundo os professores participantes desta pesquisa, o sistema educativo propôs e implantou, mas não implementou, uma forma diferente de organizar o ensino, que é o regime de ciclos. Quando eles falam de implantação, se referem às ações dos governos para prescrever, estabelecer e inserir uma nova proposta educacional. Nessa direção, implementação se refere às ações dos professores, diretores, coordenadores pedagógicos e demais trabalhadores em educação para colocar em prática as diretrizes prescritas pelo governo. Esses mesmos professores também argumentam que eles não foram preparados para esta nova forma de organização e de trabalho em ciclo ao invés 
de série e demonstram que estão buscando formas de se adaptar a essa nova organização do ensino. Dentro deste processo de adaptação, a função do professor não está claramente definida nem pelas pessoas responsáveis pela implantação dos ciclos, nem pelos próprios professores, nem pela sociedade. Não se sabe ao certo o que cabe ao professor. Essa mesma situação foi encontrada por Domingues (2004) em estudo sobre o horário de trabalho coletivo e a (re)construção da profissionalidade docente. Nesse estudo, Domingues (2004, p. 58) destaca que a ação do professor

não se limita apenas ao domínio cognitivo, mas pressupõe, também, a capacidade de dar conta das mudanças curriculares, lidar com a violência, facilitar a aprendizagem, organizar o trabalho em grupo, cuidar do equilíbrio afetivo do aluno, assumir o papel de assistente social, compor com a família no desenvolvimento de princípios éticos e morais, incluir alunos portadores de necessidades especiais.

A experiência da Iniciação Científica despertou em mim o interesse em continuar a estudar a profissão docente na escola pública contemporânea. Diante disso, participei da seleção da pós-graduação para o mestrado e tive meu projeto aprovado. $\mathrm{O}$ projeto inicial versava sobre o papel do professor na contemporaneidade. Mas, como nem tudo acontece como o previsto, este projeto sofreu algumas modificações advindas do amadurecimento intelectual e do desenvolvimento profissional pelos quais passei. Essas modificações começaram a se delinear após a realização do VIII Congresso Estadual Paulista sobre Formação de Educadores em setembro de 2005, realizado em Águas de Lindóia. Esse congresso estimulou momentos de reflexão sobre os modos de ser professor e influenciou na redefinição do objetivo central do projeto de pesquisa.

$\mathrm{Na}$ sua configuração final, o objeto central dessa pesquisa não consiste mais apenas no papel do professor no processo educacional escolar. Ele está voltado para o modo vivido de desenvolvimento profissional dos professores como possibilidade de construção de diferentes modos de ser professor na escola pública contemporânea.

Compreender como os professores estão construindo e desenvolvendo seus modos de ser e de atuar no interior da profissão docente, à luz do seu desenvolvimento profissional, passou a ser então o objetivo central deste trabalho de mestrado.

Os objetivos específicos que o orientam são os seguintes:

- identificar as percepções dos sujeitos da pesquisa sobre o seu processo de desenvolvimento profissional e suas influências no seu modo de ser professor na escola pública contemporânea; 
- investigar de que forma o tempo de carreira no magistério, que abriga a experiência e a vivência profissional, influencia o modo de ser professor;

- e contribuir com o campo de estudos sobre o desenvolvimento da profissão de professor.

Para alcançar esses objetivos, optei por sustentar este estudo nas percepções de professoras que atuam no Ciclo I do Ensino Fundamental de escolas da Rede Municipal da capital paulista. Essa opção ganhou consistência após as contribuições do exame de Qualificação ocorrido em fevereiro de 2007. O exame de Qualificação orientou sobre a necessidade de se optar por trabalhar com uma única rede de ensino porque a escolha por trabalhar com as duas redes de ensino - estadual e municipal - traria uma série de questões, como por exemplo, a forma como o regime de ciclos foi implantado em cada uma delas, que não seria possível aprofundar neste trabalho de mestrado. Diante dessa opção, três professoras do Ciclo I do Ensino Fundamental foram entrevistadas, e cada uma com diferentes anos de carreira: Isabela, três anos; Estela, 14 anos e Margareth, 23 anos. Os nomes das professoras são fictícios para preservar suas identidades.

Duas questões centrais orientaram o trabalho de pesquisa:

- O desenvolvimento profissional vivido pelas professoras entrevistadas é fruto de escolhas pessoais ou ele acontece de forma espontânea ou involuntária?

- As professoras percebem, na medida que avançam na carreira docente, os impactos do seu desenvolvimento profissional nos modos de ensinar?

Como hipótese norteadora, partimos da idéia de que os modos de ser professor não são fixos e imutáveis e que se adequam ou se modificam durante a ação do professor dentro de um contexto estabelecido. Essa hipótese se consolidou a partir do momento em que a literatura consultada $^{1}$, a experiência como professora e, principalmente, as conversas com os colegas de profissão trouxeram contribuições no sentido de evidenciar que o professor está sempre em (re)construção. Em outras palavras, ao longo dos anos da carreira o professor vai se desenvolvendo profissionalmente, vai refletindo sobre seu modo de ser e de estar na profissão e vai criando e modificando sua ação pedagógica.

\footnotetext{
${ }^{1}$ MARCELO GARCÍA (1994, 1995), ALMEIDA (1999a, 1999b, 2004a, 2004b), SOUZA (2005), IMBERNÓN (1998), SCHON (1995), NÓVOA (1998), GIMENO SACRISTÁN (1995), ALTET (2001), HAGEMEYER (2004), dentre outros.
} 
$\mathrm{Na}$ tentativa de captar o relato das experiências vividas pelas professoras, busquei o apoio da História Oral com o intuito de apreender a experiência vivida por determinados indivíduos (a profissão docente) num contexto macro social (a escola pública). O trabalho com a História Oral ajuda a conquistar a possibilidade de tecer uma análise da profissão docente a partir de depoimentos pessoais. Isso acontece porque as professoras, independentemente das escolhas pessoais, vivenciam o contexto de escolas que são singulares, mas que pertencem a uma mesma rede de ensino. Por pertencer a uma mesma rede de ensino, elas estão sujeitas às normas e regras que são colocadas pela administração central (Secretaria e Coordenadorias de Educação) a todas as escolas municipais. O trabalho do professor está sendo influenciado o tempo todo pelos programas e projetos que são gerados pela administração central e que são implantados na rede como um todo. Diante disso, um dos interesses deste trabalho é saber como cada professora, ao receber a orientação dos órgãos centrais da administração do sistema de ensino, inclui essa orientação na sua prática pedagógica. O modo como essa inclusão acontece é particular e pessoal, mas o contexto geral de trabalho não é. Por isso que o trabalho com o depoimento de alguns indivíduos permite a leitura do que acontece com um grupo social mais amplo - os professores da Rede Municipal de ensino de São Paulo - e possibilita a compreensão de que o desenvolvimento profissional de cada professor ajuda a produzir a profissão docente.

No intuito de visualizar esse desenvolvimento profissional para chegar aos modos como os professores dizem construir sua profissão, optei por realizar entrevista de cunho qualitativo, com professoras em exercício na rede pública municipal de ensino da capital paulista no ano de 2006. As entrevistas semi-estruturadas e recorrentes se mostraram excelente método de recolhimento das falas das professoras Isabela, Estela e Margareth. A entrevista semi-estruturada, com um roteiro de apoio, se mostrou um suporte importante na medida em que permitiu flexibilizar a conversa com as professoras em questão. Triviños (1987) coloca que essa maior flexibilidade consiste em poder tratar as questões na medida em que elas aparecem no relato dos sujeitos entrevistados e se tornam relevantes para o estudo. Além das entrevistas semiestruturadas, foi utilizado o recurso da entrevista recorrente (LEITE \& COLOMBO, 2006) na medida em que se pretendeu retomar contato com as fontes, visando aprofundar, esclarecer e checar informações. A entrevista recorrente pode ser caracterizada como um processo interativo no qual o sujeito pesquisador tem a oportunidade de voltar ao sujeito pesquisado e rever questões das entrevistas que não 
ficaram totalmente esclarecidas ou para complementar algum dado que precisa de maiores informações. Tanto o sujeito pesquisador como o sujeito pesquisado são atores porque o primeiro pretende conhecer o fenômeno pesquisado, mas é o segundo quem detém a vivência do mesmo.

Partindo de tudo que foi dito, esta dissertação estará organizada em quatro capítulos.

No primeiro capítulo tecemos os argumentos que justificam a realização da pesquisa e apresentamos os referenciais teóricos e o caminho metodológico que nos orientam em tal intento. Escolhemos como tema a profissão docente e como objeto de estudo o desenvolvimento profissional de professores. Queremos compreender de que forma ocorre o desenvolvimento profissional de professores que apresentam experiências de vida e de formação diferentes e que atuam na Rede Municipal de Ensino de São Paulo a fim de vislumbrar os modos de ser professor da atualidade. Partimos do pressuposto que os processos formativos influenciam diretamente o desenvolvimento profissional de professores. A construção da pesquisa contou ainda com discussões mais aprofundadas sobre a profissão docente, o desenvolvimento profissional, a carreira do magistério e as professoras da Rede Municipal de Ensino de São Paulo. Como referencial teórico utilizaremos as contribuições da História Oral e dos estudos da carreira do professor vista a partir da história de vida.

No segundo capítulo apresentamos a Rede Municipal de Ensino de São Paulo desde sua origem até os dias atuais. Trabalhamos com dados recentes dessa rede que ilustram seu tamanho e sua complexidade. Além disso, tecemos breve reflexão sobre a questão das experiências dos regimes de ensino não-seriados no Brasil e, em especial, na Rede Municipal de Ensino de São Paulo. Abordamos alguns dilemas que acompanham o contexto dos regimes não-seriados e que afetam diretamente o trabalho das professoras por nós entrevistadas.

No terceiro capítulo procuramos refletir sobre os conceitos de profissão docente e desenvolvimento profissional tendo em vista os percursos profissionais de Isabela, Estela e Margareth. Fazemos uma breve incursão sobre o surgimento da profissão de professor na Idade Moderna em Portugal e, posteriormente, no Brasil para que possamos entender como essa profissão se configura na atualidade. Damos especial destaque para a questão da profissão docente e do desenvolvimento profissional.

No capítulo quatro analisamos o percurso profissional das três professoras por nós entrevistadas a fim de compreendermos os modos como se 
configura o desenvolvimento profissional de professoras dos anos inicias do Ensino Fundamental que atuam na Rede Municipal de Ensino de São Paulo. Nessa análise centramos o foco em três categorias que nos ajudam a tecer relações entre os percursos individuais das professoras. Essas categorias: a relação com o conhecimento, a formação contínua e a autonomia.

Nas considerações finais retomamos o percurso da investigação e seus resultados. 
CAPÍtulO 1 - A construcão da pesquisa 
Esta dissertação tem por objeto de estudo o desenvolvimento profissional de professores. A escolha deste objeto tem dupla motivação. A primeira resulta da necessidade de se estudar o caminho do desenvolvimento profissional de professores em busca dos elementos definidores dos modos como ele é trilhado, tendo como referência o contexto da Rede Municipal de Ensino de São Paulo. A segunda, mais abrangente, deriva da necessidade de se (re)pensar a importância da formação inicial e contínua do professor que está atuando na escola contemporânea, uma vez que os processos formativos são parte essencial do desenvolvimento profissional de professores.

Estas duas motivações trazem à tona a relevância da reflexão sobre a formação do professor e sobre o seu desenvolvimento profissional. Almeida (1999a, p. 195) traz sua contribuição para essa reflexão ao dizer que a relação da formação contínua com a carreira docente é um dos aspectos mais complexos de se equacionar na perspectiva do desenvolvimento profissional dos professores. Em outras palavras, o desenvolvimento profissional traz em si a questão da formação contínua como um dos pré-requisitos para que ele possa acontecer. Cabe-nos, então, tentar compreender de que forma ocorre o desenvolvimento profissional de professores que apresentam experiências de vida e de formação diferentes e que atuam na Rede Municipal de Ensino de São Paulo a fim de vislumbrar os modos de ser professor da atualidade.

Assim, dentro da temática da profissão docente e frente ao desenvolvimento profissional como objeto de estudo, esta dissertação procura responder, ainda que parcialmente, a questão: $\mathrm{O}$ desenvolvimento profissional dos professores ocorre de forma distinta de acordo com o tempo de experiência e as variadas vivências ao longo da carreira?

\section{1- Justificativa}

\subsection{Profissão docente e desenvolvimento profissional}

O estudo da profissão docente, tendo como objeto de discussão o desenvolvimento profissional de professores, mostrou-se relevante porque algumas questões trazidas pela literatura como, por exemplo, as relações entre transformações sociais e mudanças da profissão docente, estimularam novos modos de aproximação com a questão motivadora da pesquisa. Sobre transformações sociais e profissão docente, a autora portuguesa Ana Paula Caetano debruça seus olhares sobre o fato de que 
neste fim de século, em que se profetizam as grandes mudanças sociais trazidas pela sociedade da informação que não deixarão de se refletir sobre as funções da escola e os papéis a desempenhar pelos professores,tornam-se cada vez mais importantes os estudos que nos levem a refletir de forma mais fundamentada sobre a profissão. Só dessa reflexão fundamentada poderá emergir a reconstrução da profissão docente de que todos sentimos necessidades (CAETANO, 1997, p. 191).

Outro autor que também estuda a relação entre as transformações sociais e a profissão docente é o norte americano Andy Hargreaves. Em seu livro Profesorado, cultura y postmodernidad: cambian los tiempos, cambia el profesorado, ele coloca que se por um lado o mundo está cada vez mais pós-industrial e pós-moderno devido ao desenvolvimento acelerado, à diversidade cultural, à complexidade tecnológica e às incertezas científicas, por outro a escola continua com as características de uma escola moderna, que ainda persegue alguns objetivos anacrônicos e que apresenta estruturas inflexíveis (HARGREAVES, 1999). Neste mesmo livro, Hargreaves aponta que as mudanças pelas quais passam a educação e os sistemas educativos estão acontecendo em diversos países, como por exemplo: Grã-Bretanha, Estados Unidos, Canadá, Austrália, etc. O autor observa então que este é um fenômeno de abrangência global. Paquay (2001, p. 142) caminha neste mesmo sentido e vai mais além ao dizer que a evolução da sociedade provocou uma mudança das funções da escola e, conseqüentemente, dos papéis do professor.

Esse fenômeno global de mudanças nos sistemas educativos oriundos das transformações sociais relatado por Caetano (1997), Hargreaves (1999) e Paquay (2001) também se verifica no Brasil. Sobre esse fenômeno entre nós, Almeida (2004b, p. 168) revela que novas demandas têm sido colocadas [aos professores] pela reordenação do mundo do trabalho, impulsionadas pelas novas tecnologias e pelo movimento mundial de globalização. Da escola passou-se a exigir a formação de um novo cidadão trabalhador.

Continuando essa reflexão sobre as influências que a evolução da sociedade coloca ao ensino, Almeida (2004a, p. 170) fala que devido à verdadeira avalanche de inovações científicas e tecnológicas, que apontam para uma organização bastante diferenciada do mundo, o papel dos professores não pode continuar a ser o mesmo. É nessa direção que esta pesquisa de mestrado busca trazer suas contribuições. Como o professor está desenvolvendo seu trabalho em meio a essas transformações sociais? Essas novidades tecnológicas e científicas trazem novos contornos à tarefa de 
ensinar? Ao longo da carreira o professor que já é experiente deve ter se deparado com inovações sociais, tecnológicas e curriculares. Como ele lidou com essas inovações? O que foi apreendido? O que foi descartado? Houve uma formação para se lidar com as novas demandas? E o professor iniciante? Como ele se coloca diante das obrigações da carreira na relação com as transformações da sociedade? Não pretendemos responder a essas perguntas isoladamente. Considerando a importância de todas elas, podemos visualizar a importância de se ouvir tanto o professor mais experiente, quanto o menos experiente para saber quais os modos de ser professor na escola pública contemporânea.

Simultaneamente ao contexto de mudanças sociais e de avanços tecnológicos e científicos, Almeida (2004a, p. 168) verifica que houve uma diminuição das responsabilidades educativas de outros agentes sociais, especialmente da família e isso gerou um

aumento das exigências com relação ao professor, que além de ensinar de maneira competente, deve ser facilitador da aprendizagem, organizador de atividades coletivas, orientador psicológico, social e sexual, além de dar atenção aos alunos com necessidades especiais integrados na sala de aula, já que essa integração está cada vez mais presente em nossas redes de ensino.

Esse aumento das exigências do trabalho do professor leva à necessidade de se repensar a escola. Dentro dessa perspectiva, a inclusão do professor no processo de elaboração das propostas de mudança educacional é peça chave para a construção de uma escola democrática pautada num trabalho coletivo, coerente e conseqüente. Em outras palavras, pensamos que como o professor é a pessoa diretamente ligada a todos os atores e sujeitos do processo educacional escolar, ele deve ser ouvido no momento de elaboração de novas diretrizes que vão orientar o seu próprio trabalho. Essas transformações educativas precisam levar em conta os olhares dos professores. Caso contrário, seus resultados correm sério risco de não obter sucesso porque, como bem nos lembra Almeida (2004a), são os professores que em última instância, decidem se querem mudar suas práticas ou não. Não podemos minimizar essa decisão dos professores à simples anuência ou resistência frente à novidade educacional. A

mudança educacional pressupõe nova maneira de planejar, ensinar, organizar o conhecimento, avaliar,etc. Daí o professor ter de aprender a fazê-lo segundo as novas bases propostas, o que significa que a mudança só se desenvolve dentro das escolas se for concretizada pelo professor. Por isso ela não pode ser imposta por decreto (ALMEIDA, 1999b, p. 253). 
Questões como nova maneira de planejar, ensinar, organizar o conhecimento e avaliar nos direcionam para a compreensão do desenvolvimento profissional de professores. Esse desenvolvimento sofre influência direta dessas mudanças pelas quais passam a profissão, o ensino e a escola.

Outra autora que também estuda a questão das mudanças educacionais é a portuguesa Luiza Cortesão. Ela coloca que os professores vão precisar usar seus conhecimentos para

repensar formas (e até conteúdos) de trabalho que possam ir ao encontro dos interesses, que valorizem os saberes, que não desrespeitem os valores, que aproveitem as competências que os alunos sempre têm, seja qual for a sua origem social e étnica, mas que a sociedade e a escola atuais nem aproveitam, nem valorizam e nem aceitam (CORTESÃO, 2002, p. 69).

Uma das propostas mais importantes de mudança educacional que se fez presente na rede pública de ensino em várias cidades e em vários estados do Brasil foi a implantação de regimes de ensino não seriados. Sobre isso Jeffrey (2006, p. 36) aponta que

medidas como os ciclos e a progressão escolar são implementadas por diversos governos, com o propósito de contribuírem no enfrentamento e na solução destes problemas [de aprendizagem], favorecendo a democratização do ensino e o cumprimento do direito à educação, estabelecidos tanto na Constituição de 1988 como na LDB 9394/96.

Diante deste contexto de mudanças educacionais, Hagemeyer (2004) levanta uma questão importante: como redimensionar o papel do professor e suas funções frente à validação de todas as formas de ser e estar na sociedade atual? Essa questão está presente em nossa pesquisa porque nos remete aos modos de ser professor na escola pública contemporânea e ao desenvolvimento profissional de professores. A facilidade de acesso ao conhecimento ajuda a colocar em xeque um dos principais alicerces da escola: a transmissão do conhecimento. Não podemos mais dizer que a escola é a principal responsável por transmitir este bem imaterial à população. $\mathrm{O}$ conhecimento está disponível em toda parte. Por isso, dizer que o aluno só aprende na escola não é mais uma inverdade. Além disso, os professores não têm mais como 'obrigar' o aluno a estudar para tirar boa nota e passar de ano porque o regime de ciclos limita a possibilidade de retenção do aluno por defasagem de rendimento. O que cabe ao professor fazer diante desses dois novos fatores, conhecimento que está em todo lugar e 
nota não é mais pré-requisito, que não são mais a essência do aprendizado na escola? Como ele redimensiona sua prática diante deste novo contexto?

Entendemos que essas questões justificam a realização de pesquisas voltadas a investigar como o desenvolvimento profissional docente possibilita diferentes modos de ser professor. No nosso caso, interessa-nos particularmente discutir como os professores vêem seu desenvolvimento profissional e como refletem sobre seu próprio percurso profissional, tendo em vista as decorrências das experiências vividas - frutos de escolhas pessoais ou de contingências estruturais do contexto de trabalho. Os distintos caminhos percorridos durante anos de experiência resultam em distintos modos de ser professor? Ao longo do percurso profissional ocorrem mudanças no modo de pensar a prática? Essas questões nos mobilizam para aprofundar a compreensão sobre como o modo de ser professor de cada docente é influenciado pelo contexto de trabalho deste professor. Nosso foco específico está centrado em analisar o modo como acontece o desenvolvimento profissional de professores e sua repercussão nos modos de atuação e de compreensão do próprio papel que desempenham na escola pública contemporânea.

Ao longo dos anos da carreira, o professor, ao refletir sobre seu modo de ser e de estar na profissão, cria e modifica sua ação pedagógica e desenvolve-se profissionalmente. Sobre esse aspecto, Altet (2001, p. 27) nos diz que:

o professor pode planejar, preparar seu roteiro, mas continua havendo uma parte de 'aventura', ligada aos imprevistos que têm origem nessas ações em andamento e no desconhecido proveniente das reações dos alunos. Isto requer uma grande quantidade de tomada de decisão, uma mobilização dos conhecimentos dentro da ação e, até mesmo, uma modificação de decisões na ação em sala de aula.

O esforço por compreender os possíveis modos de ser professor no dia-adia em uma escola pública contemporânea nos aproxima de sujeitos que carregam em si maneiras distintas e variadas de desenvolvimento profissional, vividas ao longo de anos de carreira, bem como as experiências culturais, sociais, intelectuais, cognitivas, emocionais, psicológicas pelas quais esses professores passaram.

Frente ao proposto no parágrafo anterior, estivemos atentas durante toda a pesquisa à seguinte afirmação de Nóvoa (1998, p. 28): O professor é a pessoa. E uma parte importante da pessoa é o professor. Essa atenção especial aconteceu porque pensamos que os modos de ser professor carregam em si boa parte dos modos de ser da própria pessoa. O modo como cada um se apropria do sentido da sua história pessoal e profissional influencia os modos de ser professor. E esses modos estão marcados por 
ideais educativos próprios, pelas idéias que orientam as instituições onde os professores atuam/atuaram, pela assunção de práticas e métodos pedagógicos com os quais cada professor se identifica, pela crença no potencial de sua ação, pela escolha de estilos pessoais de refletir sobre a ação, dentre outras coisas.

Dando prosseguimento à nossa reflexão, outro autor que nos ajuda a pensar a questão do desenvolvimento profissional é Donald Schön (1995). Segundo ele todos os professores constroem, reconstroem e modificam seus modos de ser professor de acordo com o contexto educativo escolar no qual estão inseridos através de momentos de reflexão. Nessa direção podemos aferir que os modos de ser professor não são estruturas fixas e imutáveis, muito pelo contrário, eles são flexíveis e mutáveis. Em decorrência dessa idéia da flexibilidade Schön (1995, p. 82-83), usando as palavras de Tolstoi, diz que

o melhor professor será o que tiver uma resposta pronta para a questão que preocupa o aluno. Estas explicações dão ao professor o conhecimento do maior número possível de métodos, a capacidade de inventar novos métodos e, acima de tudo, não provocam uma adesão cega a um método, mas a convicção que todos os métodos são unilaterais e que o melhor método será o que der a melhor resposta a todas as dificuldades possiveis que o aluno tiver, quer dizer, não um método, mas uma arte e um talento.

Entendemos que o conhecimento do maior número possível de métodos, a capacidade de inventar novos métodos e a não adesão cega a um método são características que precisam estar presentes no desenvolvimento profissional de professores. Vamos agora à reflexão sobre porque optamos por tomar a Rede Municipal de Ensino de São Paulo como referência para o nosso estudo sobre a profissão docente e o desenvolvimento profissional.

\subsection{A carreira do magistério}

O estudo do desenvolvimento profissional pressupõe uma reflexão sobre a carreira do professor porque é no exercício da profissão que ele desenvolve sua profissionalidade. A profissionalidade, segundo Gimeno Sacristán (1995, p. 65), é $a$

afirmação do que é específico na ação docente, isto é, o conjunto de comportamentos, conhecimentos, destrezas, atitudes e valores que constituem a especificidade de ser professor [...] o conceito de profissionalidade docente está em permanente elaboração, devendo ser analisado em função do momento histórico concreto e da realidade social que o conhecimento escolar pretende legitimar; em suma, tem de ser contextualizado. 
A profissionalidade é subjetiva e está diretamente relacionada com as experiências vividas por cada professor nos seus diversos ambientes de trabalho.

A idéia de profissionalidade fornece subsídios para que o desenvolvimento profissional possa ser entendido com maior clareza. Por isso se faz necessária uma reflexão sobre o conceito de carreira, já que o desenvolvimento profissional e a profissionalidade docente acontecem no seio desta.

Um dos estudiosos do conceito de carreira é Maurice Tardif. Este autor, partindo dos estudos da Escola de Chicago, concebe a carreira como a trajetória dos indivíduos através da realidade social e organizacional das ocupações, pouco importa seu grau de estabilidade e sua identidade. Ele entende também que a carreira consiste numa seqüência de fases de integração numa ocupação e de socialização na subcultura que a caracteriza (TARDIF, 2005, p. 79). Nessa direção, ele nos ajuda a compreender que a configuração da carreira sofre influência da organização que a abriga. Cada instituição, seja a Secretaria de Educação, a Diretoria de Ensino, a Coordenadoria de Educação ou qualquer outra, apresenta 'regras' diversas para a configuração das carreiras no seu âmbito de gestão.

Para Tardif (2005, p. 80), o estudo da carreira procede, assim, tanto da análise da posição ocupada pelos indivíduos num dado momento do tempo quanto de sua trajetória ocupacional. Não podemos esquecer também que a carreira não corresponde, hoje, a um modelo único. As carreiras ultrapassam as fronteiras das profissões legitimadas e regidas por sistemas distintos e diversos. Nessa direção, deixamos claro que partimos da carreira do magistério instituída na Rede Municipal de Ensino de São Paulo como parâmetro e referência para nosso estudo sobre o desenvolvimento profissional. Essa carreira está amparada pelo Estatuto do Magistério Público Municipal, instituído pela LEI nº 11229/92.

Tomamos então a Rede Municipal como porta de entrada para a compreensão do desenvolvimento profissional docente. Apesar dessa rede ser a nossa referência, precisamos considerar o fato de que as três professoras vivenciaram, ao longo de suas carreiras, experiências em outras redes de ensino, com destaque para a Rede Estadual de São Paulo. Essas professoras transitaram e continuam transitando entre as duas redes públicas e Margareth esteve também, por um dado tempo, na rede privada. A carreira é diferente em cada uma dessas redes. Não há como compreender o desenvolvimento profissional sem extrapolar os limites da Rede Municipal porque o percurso profissional de cada professora vai além de suas experiências nessa rede. Por 
isso compreendemos que a carreira docente pode ser compreendida em duas dimensões: a institucional, de acordo com cada rede de ensino, e a pessoal, de acordo com as necessidades e as possibilidades da vida de cada professor.

Tardif (2005, p. 80-81) agrega uma terceira dimensão, que é a subjetiva. Para ele essa dimensão

remete ao fato de que os indivíduos dão sentido à sua vida profissional e se entregam a ela como atores cujas ações e projetos contribuem para definir e construir sua carreira. Desse ponto de vista, a modelação de uma carreira situa-se na confluência entre a ação dos indivíduos e as normas e papéis que decorrem da institucionalização das ocupações, papéis estes que os indivíduos devem 'interiorizar' e dominar para fazerem parte de tais ocupações.

Considerando então o contexto da Rede Municipal de Ensino e a contribuição de Tardif, entendemos que a realidade profissional dificulta a manutenção do professor em uma única rede de ensino, por isso há o trânsito entre várias redes. $\mathrm{O}$ professor precisa encontrar meios de aumentar sua renda e por isso trabalha em mais de um emprego e, muitas das vezes, em mais de uma rede de ensino. Em decorrência disso, seria uma inverdade atribuir um conceito à carreira do professor da rede pública que não levasse em consideração essas questões da realidade profissional vivida pelo professor no Brasil contemporâneo.

Quando escolhemos trabalhar com professoras com diferentes anos de experiência no magistério, quisemos abarcar a quase totalidade da duração desta carreira. Por isso precisamos encontrar um conceito que dê conta de explicitar o contexto de trabalho do professor e que nos leve a compreender o desenvolvimento profissional deste por meio da análise de seu percurso na carreira. Nessa direção, concordamos com Tardif (2005, p. 81) quando este coloca que a carreira é fruto das transações contínuas entre as interações dos indivíduos e as ocupações; essas transações são recorrentes, ou seja, elas modificam a trajetória dos indivíduos bem como as ocupações que eles assumem. Acrescentamos a essa compreensão o fato de que, no caso do magistério, a carreira é regulamentada por normas, valores e condutas que o profissional deve seguir. Entendemos, então, que a carreira dos professores da Rede Municipal, da Rede Estadual e da Rede Privada apresentam diferenças.

O próprio Tardif $(2005$, p. 81$)$ afirma que a carreira revela o caráter subjetivo, experiencial e idiossincrático do saber do professor. A partir dessa afirmação, podemos estabelecer dois fios condutores para compreender o conceito de 
carreira que utilizaremos nessa dissertação: o primeiro refere-se diretamente à questão institucional, na qual estão presentes as normas, condutas e valores colocados pelas redes de ensino que gerenciam a escola e, por sua vez, a carreira dos professores. Muitas vezes essas normas, condutas e valores estão pressupostos num Estatuto do Magistério que regulamenta e legitima a profissão. As Redes Municipal e Estadual de Ensino de São Paulo possuem tal instrumento. Já a rede particular não apresenta um documento que abarque toda a rede. Cada escola ou cada grupo educacional estabelece suas próprias diretrizes, que podem estar claramente presentes num estatuto ou não. $\mathrm{O}$ segundo fio condutor que nos orienta na definição do conceito de carreira diz respeito às experiências pessoais vividas pelos professores ao longo do seu desenvolvimento. Como já dissemos anteriormente, as realidades profissional, social e econômica colocam aos professores a necessidade de transitarem entre as redes de ensino na busca de melhores condições de trabalho e de vida. Por isso não podemos deixar de levar em consideração que as experiências adquiridas pelo professor em todas as suas vivências profissionais constituem elementos definidores de sua profissionalidade docente e contribuem para o seu desenvolvimento profissional.

Considerando então que o conceito de carreira que ajuda a impulsionar nosso trabalho é aquele que coloca em destaque a relação existente entre o percurso profissional - que é individual e pessoal - e as práticas institucionais das redes de ensino. O professor carrega o conjunto de suas experiências para sua atuação profissional na escola. Então, não podemos descartar a importância das escolhas pessoais do professor no contexto da carreira entendida como percurso profissional individual que se insere em diferentes contextos organizacionais. Não há como entender o desenvolvimento profissional de um professor que circulou por mais de uma rede de ensino delimitando seu percurso a uma única rede.

Outro autor que também trabalha com conceito de carreira construído na Escola de Chicago é Huberman (2000). Para ele

o conceito de 'carreira' apresenta, vantagens diversas. Em primeiro lugar, permite comparar pessoas no exercício de diferentes profissões. Depois, é mais focalizado, mais restrito que o estudo da 'vida' de uma série de indivíduos. Por outro lado, e isso é importante, comporta uma abordagem a um tempo psicológica e sociológica. Trata-se, com efeito, de estudar o percurso de uma pessoa numa organização (ou numa série de organizações) e bem assim de compreender como as características dessa pessoa exercem influência sobre a organização e são, ao mesmo tempo, influenciadas por ela. 
Essa abordagem psicológica e sociológica abre-nos a possibilidade de contextualizar a carreira do magistério de acordo com os diferentes contextos institucionais no qual os professores exercem o seu trabalho e, ao mesmo tempo, nos permite formular a idéia de que há uma carreira pessoal, no âmbito das escolhas do percurso profissional de cada professor, que se relaciona com a carreira institucional.

Pelas reflexões que fizemos sobre o conceito de carreira, adotaremos para nosso trabalho que esse conceito abraça duas vertentes que se complementam entre si: a vertente pessoal, de acordo com as escolhas de cada professor; e a vertente institucional, de acordo com as especificidades de cada rede de ensino. Dito de outra forma, a carreira como percurso profissional é diferente da carreira estabelecida por um estatuto, mas ambas ajudam a formar a carreira do magistério vivenciada por cada professor. A professora Margareth, uma de nossas entrevistadas, ilustra bem essa questão ao dizer que

o conhecimento que você vai adquirindo em uma rede de ensino você vai passando pra outra. O professor que atua na Rede Municipal, na Rede Estadual e na Rede Particular é o mesmo. Então eu não entro na Rede Estadual de uma forma e na Municipal de outra. Eu posso ter uma certa autonomia em uma ou em outra, mas o meu trabalho vai ser, dentro de sala de aula, o mesmo.

Portanto, quando falarmos em carreira, o leitor precisa estar atento ao fato de que estaremos nos referindo também ao percurso profissional do professor como um todo, porque acreditamos que o desenvolvimento profissional docente acontece a partir das múltiplas experiências que esse profissional vivencia ao longo do seu percurso na profissão, ou seja, ao longo da carreira do magistério. Como temos a Rede Municipal como referência, vejamos como a carreira do magistério está instituída no Estatuto do Magistério Público Municipal de São Paulo (LEI nº 11229/92).

O Título II da LEI 11229/92 trata especificamente da carreira do magistério. O Capítulo I deste Título apresenta a configuração da carreira, que carreira é composta por três classes distintas:

Classe I:

a) Professor Adjunto de Educação Infantil;

b) Professor Adjunto de Ensino Fundamental I;

c) Professor Adjunto de Ensino Fundamental II; e

d) Professor Adjunto de Ensino Médio. 
Classe II:

a) Professor Titular de Educação Infantil;

b) Professor Titular de Ensino Fundamental I;

c) Professor Titular de Ensino Fundamental II; e

d) Professor Titular de Ensino Médio.

Classe III:

a) Coordenador Pedagógico;

b) Diretor de Escola; e

c) Supervisor Escolar.

O provimento desses cargos se faz por ingresso ou acesso mediante aprovação em concurso público de provas e títulos. Precisamos dizer aqui que o Estatuto do Magistério Público Municipal de 1992 foi alterado pela LEI n 14660 de 26 de dezembro de 2007. Essa LEI consolida o Estatuto dos Profissionais da Educação Municipal e traz alterações significativas para a carreira do magistério. A principal delas está relacionada com a configuração da carreira. Se antes havia três classes dentro dessa carreira, a partir de $1^{\circ}$ de janeiro de 2008 a carreira passa a estar configurada da seguinte forma:

I - Classe dos Docentes

a) Professor de Educação Infantil;

b) Professor de Educação Infantil e Ensino Fundamental I;

c) Professor de Ensino Fundamental II e Ensino Médio.

II - Classe dos Gestores

a) Coordenador Pedagógico;

b) Diretor de Escola;

c) Supervisor Escolar.

A partir da promulgação dessa nova lei, não há mais a diferença entre professores adjuntos e professores titulares. Todos passam a compor a mesma classe docente. A principal diferença entre essas duas classes de professores consistia na questão de que os professores adjuntos estavam lotados nas Coordenadorias de Educação enquanto que os professores titulares estavam lotados nas escolas. Em outras 
palavras, os titulares escolhiam suas aulas nas escolas antes dos adjuntos e esses ficavam com as aulas que sobravam dessa escolha, podendo ir trabalhar em qualquer escola da sua região de lotação. Se esses professores adjuntos não conseguissem aulas/turmas, eles ficavam na escola como professores eventuais, para cobrir as ausências de outros professores.

Como as professoras por nós entrevistadas ainda não vivenciaram a experiência da mudança do Estatuto que aconteceu em dezembro de 2007, no momento da análise levaremos em consideração a configuração da carreira instituída pela LEI $\mathrm{n}^{\circ}$ 11229/92, tendo em vista que a profissão docente no âmbito da Rede Municipal apresentará novas perspectivas, demandas e dilemas a partir de $1^{\circ}$ de janeiro de 2008.

Voltando ao contexto da carreira do magistério municipal, os professores são enquadrados em três categorias distintas: a) categoria 1 - habilitação em nível médio; b) categoria 2 - habilitação em licenciatura curta; c) categoria 3 - habilitação em licenciatura plena ou graduação correlata. Cada professor, independentemente da categoria a qual está vinculado, pode escolher sua jornada de trabalho ao final de cada ano letivo para vigorar a partir do ano letivo subseqüente. A tabela abaixo esboça a configuração dessas jornadas de trabalho docente. Essas jornadas estão expressas em horas aula e horas atividade semanais:

\section{TABELA 1 - Jornada de Trabalho Docente}

\begin{tabular}{|l|c|c|c|}
\hline \multicolumn{1}{|c|}{ Denominação } & Horas aula & Horas atividade & Total de Horas \\
\hline JB - Jornada Básica & 18 & 2 & 20 \\
\hline JEA - Jornada Especial Ampliada & 25 & 5 & 30 \\
\hline JEI - Jornada Especial Integral & 25 & 15 & 40 \\
\hline
\end{tabular}

O Estatuto do Magistério coloca três tipos de jornada que podem ser escolhidas pelos professores: JB - Jornada Básica (18 horas aula e 2 horas atividade); JEA - Jornada Especial Ampliada (25 horas aula e 5 horas atividade) e JEI - Jornada Especial Integral (25 horas aula e 15 horas atividade). As horas atividade da JB e da JEA podem ser cumpridas individualmente. Do total das 15 horas atividade da JEI, 8 devem ser cumpridas em horário coletivo de trabalho e 5 podem ser cumpridas individualmente, sendo que três dessas cinco são na escola e as outras duas em local de livre escolha. 
O professor que opta pela JB tem um salário ' $x$ ', o que opta pela JEA tem uma quantia a mais neste salário ' $x$ ' e o que escolhe a JEI tem um salário ainda maior. Ou seja, quanto maior for a jornada de trabalho do professor, maior será sua remuneração. A prefeitura de São Paulo inova ${ }^{2}$ ao reconhecer que a formação contínua dos professores faz parte de sua atividade e inclui na jornada docente o tempo de estudo e formação. Nessa direção, Domingues (2004, p. 26) coloca que a concretização do Estatuto do Magistério e o investimento na formação contínua dos professores foram entendidas

como fatores condicionantes na reconstrução coletiva do trabalho na escola e propulsores de um processo de educação continuada, que visava o aperfeiçoamento dos educadores na busca da emancipação e da transformação da prática pedagógica pela possibilidade de o professor ver-se como sujeito do exercício pedagógico (...) Para atingir o objetivo dessa concepção, foi criada a estrutura dos grupos de formação. Estes, por meio de dinâmica metodológica, observação, registro, síntese, avaliação e planejamento, buscavam criar condições para que o educador desvelasse a teoria que embasa a sua prática, à medida que se percebia como produtor de conhecimento.

O Estatuto do Magistério Público Municipal também trouxe outra novidade para a carreira do docente do município: a possibilidade de promoção na carreira via evolução funcional. A partir da criação desse Estatuto os professores conquistaram o direito de ter cursos e atividades ligadas ao saber (congresso, palestras, simpósios, etc) válidos como pontos para a evolução na carreira. A primeira evolução é feita, obrigatoriamente, ao final do segundo ano no cargo por tempo de serviço ou por tempo de serviço combinado com pontuação de certificados e/ou diplomas. As evoluções subsequientes podem ser solicitadas anualmente, desde que o professor tenha pontuação suficiente para isso. Se em um ano o docente não alcançar pontos suficientes para evoluir na carreira, esse professor precisa esperar alcançar esses pontos através da transformação de tempo em títulos, e isso demora mais tempo.

Para evoluir, os professores apresentam seus certificados e diplomas, devidamente registrados, nas secretarias de suas escolas; estes certificados e diplomas vão para um banco de dados da prefeitura que lhes atribui pontos; esses pontos são somados e de acordo com a pontuação adquirida, o professor, de acordo com sua

\footnotetext{
${ }^{2}$ A gestão da prefeita Luiza Erundina do PT (1989-1992) contou com a participação de Paulo Freire à frente da Secretaria Municipal de Educação. A gestão Paulo Freire se configurou como progressista e democrática. Em meio a esse contexto foi criado o Estatuto do Magistério Público Municipal que veio regulamentar a carreira do magistério municipal e trouxe benefícios e garantias para o conjunto dos profissionais da educação.
} 
jornada de trabalho, avança numa tabela de números e letras (ver Tabelas 2, 3 e 4). A evolução por número acontece mediante interesse do próprio professor, a evolução por letras ocorre via promoção por merecimento que é um processo interno do sistema de pessoal da prefeitura, que se encarrega de selecionar os servidores que evoluirão por letra.

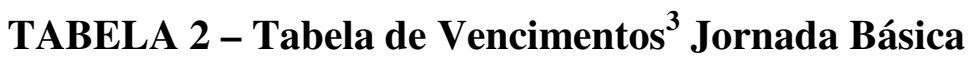

\begin{tabular}{|c|r|r|r|r|r|}
\hline \multicolumn{7}{|c|}{ Jornada Básica - 20 horas } \\
\hline $\mathbf{Q P E}$ & $\mathbf{A}$ & $\mathbf{1}$ & $\mathbf{C}$ & \multicolumn{1}{c|}{ D } & \multicolumn{1}{c|}{ E } \\
\hline $\mathbf{1 1}$ & 514,61 & 548,08 & 583,71 & 621,68 & 662,06 \\
\hline $\mathbf{1 2}$ & 548,08 & 583,71 & 621,68 & 662,06 & 705,08 \\
\hline $\mathbf{1 3}$ & 583,71 & 621,68 & 662,06 & 705,08 & 750,89 \\
\hline $\mathbf{1 4}$ & 621,68 & 662,06 & 705,08 & 750,89 & 799,72 \\
\hline $\mathbf{1 5}$ & 662,06 & 705,08 & 750,89 & 799,72 & 851,71 \\
\hline $\mathbf{1 6}$ & 705,08 & 750,89 & 799,72 & 851,71 & 907,12 \\
\hline $\mathbf{1 7}$ & 750,89 & 799,72 & 851,71 & 907,12 & 966,01 \\
\hline $\mathbf{1 8}$ & 799,72 & 851,71 & 907,12 & 966,01 & $1.028,85$ \\
\hline $\mathbf{1 9}$ & 851,71 & 907,12 & 966,01 & $1.028,85$ & $1.095,76$ \\
\hline $\mathbf{2 0}$ & 907,12 & 966,01 & $1.028,85$ & $1.095,76$ & $1.166,99$ \\
\hline $\mathbf{2 1}$ & 966,01 & $1.028,85$ & $1.095,76$ & $1.166,99$ & $1.242,79$ \\
\hline
\end{tabular}

\footnotetext{
${ }^{3}$ As Tabelas 3, 4 e 5 expressam valores em reais (R\$). Esses dados foram extraídos do site do Sindicato dos Profissionais em Educação do Ensino Municipal - SINPEEM. Acessado em outubro de 2007 no endereço http://www.sinpeem.com.br/materias.php?cd_secao=49\&codant=
} 
TABELA 3 - Tabela de Vencimentos Jornada Especial Ampliada

\begin{tabular}{|c|r|r|r|r|r|}
\hline \multicolumn{7}{|c|}{ Jornada Especial Ampliada - 30 horas } \\
\hline QPE & \multicolumn{1}{c|}{$\mathbf{A}$} & \multicolumn{1}{c|}{ B } & C & \multicolumn{1}{c|}{ D } & \multicolumn{1}{c|}{ E } \\
\hline $\mathbf{1 1}$ & 771,97 & 822,18 & 875,58 & 932,52 & 993,13 \\
\hline $\mathbf{1 2}$ & 822,18 & 875,58 & 932,52 & 993,13 & $1.057,66$ \\
\hline $\mathbf{1 3}$ & 875,58 & 932,52 & 993,13 & $1.057,66$ & $1.126,40$ \\
\hline $\mathbf{1 4}$ & 932,52 & 993,13 & $1.057,66$ & $1.126,40$ & $1.199,63$ \\
\hline $\mathbf{1 5}$ & 993,13 & $1.057,66$ & $1.126,40$ & $1.199,63$ & $1.277,57$ \\
\hline $\mathbf{1 6}$ & $1.057,66$ & $1.126,40$ & $1.199,63$ & $1.277,57$ & $1.360,63$ \\
\hline $\mathbf{1 7}$ & $1.126,40$ & $1.199,63$ & $1.277,57$ & $1.360,63$ & $1.449,12$ \\
\hline $\mathbf{1 8}$ & $1.199,63$ & $1.277,57$ & $1.360,63$ & $1.449,12$ & $1.543,34$ \\
\hline $\mathbf{1 9}$ & $1.277,57$ & $1.360,63$ & $1.449,12$ & $1.543,34$ & $1.643,61$ \\
\hline $\mathbf{2 0}$ & $1.360,63$ & $1.449,12$ & $1.543,34$ & $1.643,61$ & $1.750,40$ \\
\hline $\mathbf{2 1}$ & $1.449,12$ & $1.543,34$ & $1.643,61$ & $1.750,40$ & $1.864,22$ \\
\hline
\end{tabular}

TABELA 4 - Tabela de Vencimentos Jornada Especial Integral

\begin{tabular}{|c|c|c|c|c|c|}
\hline \multicolumn{7}{|c|}{ Jornada Especial Integral - 40 horas } \\
\hline QPE & A & B & C & D & E \\
\hline $\mathbf{1 1}$ & $1.029,25$ & $1.096,14$ & $1.167,41$ & $1.243,36$ & $1.324,12$ \\
\hline $\mathbf{1 2}$ & $1.096,14$ & $1.167,41$ & $1.243,36$ & $1.324,12$ & $1.410,16$ \\
\hline $\mathbf{1 3}$ & $1.167,41$ & $1.243,36$ & $1.324,12$ & $1.410,16$ & $1.501,80$ \\
\hline $\mathbf{1 4}$ & $1.243,36$ & $1.324,12$ & $1.410,16$ & $1.501,80$ & $1.599,43$ \\
\hline $\mathbf{1 5}$ & $1.324,12$ & $1.410,16$ & $1.501,80$ & $1.599,43$ & $1.703,42$ \\
\hline $\mathbf{1 6}$ & $1.410,16$ & $1.501,80$ & $1.599,43$ & $1.703,42$ & $1.814,24$ \\
\hline $\mathbf{1 7}$ & $1.501,80$ & $1.599,43$ & $1.703,42$ & $1.814,24$ & $1.932,06$ \\
\hline $\mathbf{1 8}$ & $1.599,43$ & $1.703,42$ & $1.814,24$ & $1.932,06$ & $2.057,71$ \\
\hline $\mathbf{1 9}$ & $1.703,42$ & $1.814,24$ & $1.932,06$ & $2.057,71$ & $2.191,50$ \\
\hline $\mathbf{2 0}$ & $1.814,24$ & $1.932,06$ & $2.057,71$ & $2.191,50$ & $2.333,97$ \\
\hline $\mathbf{2 1}$ & $1.932,06$ & $2.057,71$ & $2.191,50$ & $2.333,97$ & $2.485,58$ \\
\hline
\end{tabular}

A sigla QPE significa Quadro dos Profissionais de Educação. A primeira referência que um professor pode ter quando entra na rede municipal, independentemente da sua jornada de trabalho, é a QPE 11 - A. Todos os professores da educação infantil e do Ensino Fundamental I ingressam na carreira por esta referência. O QPE 11 indica que o professor só possui como formação inicial o curso Normal em 
nível médio. Quando o professor possui um diploma de graduação, ele é enquadrado na referência QPE 14 - A. Todos os professores do Ensino Fundamental II e do Ensino Médio ingressam na carreira já com esta referência porque um dos pré-requisitos para o cargo é possuir graduação em licenciatura plena. Quanto mais se avança nas letras e nos números, um valor ' $\mathrm{x}$ ' é incorporado ao salário padrão. Por exemplo, um professor em Jornada Especial Ampliada que tem a referência QPE $14-A$ recebe o mesmo salário padrão que um professor, também na mesma jornada, que apresenta referência $Q P E 11$ - D. Um professor em Jornada Especial Integral $Q P E 13-E$ recebe o mesmo salário padrão que um professor na $Q P E 17-A$ que se encontra na mesma jornada.

Entendemos que a criação de um Estatuto que regulamenta a carreira docente no âmbito da Rede Municipal de Ensino de São Paulo inova ao trazer benefícios para os profissionais da educação como, por exemplo, a possibilidade de evolução na carreira e a promoção por merecimento. A evolução e a promoção visam a estimular o professor a continuar seu processo de formação contribuindo, desta forma, para o seu desenvolvimento profissional. E é importante que não nos esqueçamos que esse Estatuto nasce no mesmo momento em que a proposta dos ciclos está sendo colocada para a rede como um todo. Percebe-se que a organização do regime em ciclos e a criação do Estatuto do Magistério são frutos de uma mesma política pública de melhoria da escola pública municipal.

Por compreender que a criação de um Estatuto que regulamenta a carreira traz inovações para a profissão do professor da Rede Municipal e por ser esta nossa referência para a análise do desenvolvimento profissional escolhemos como baliza inicial para a presente pesquisa o ano de 1992, que é o ano de criação do Estatuto do Magistério Público Municipal, e como baliza final, o ano de 2007 porque foi o ano em que recolhemos as últimas entrevistas com as professoras Margareth, Estela e Isabela.

Continuando a reflexão sobre a carreira do professor, podemos verificar que a carreira instituída pelo Estatuto do Magistério Público Municipal está configurada de modo vertical na medida em que, conforme Becker (apud Bolívar, 2002), a carreira vertical se refere à possibilidade de alcançar outras funções mais prestigiadas e melhor remuneradas dentro do próprio magistério, ou do sistema de ensino. Se o professor não ascender verticalmente na carreira, não alçar outros cargos, ele permanecerá na mesma ocupação. Diante disso, compreendemos que a ascensão na carreira está ligada ao desenvolvimento profissional apenas parcialmente porque este independe da ocorrência 
daquela. O desenvolvimento profissional é um fenômeno mais amplo que abarca todas as experiências profissionais e pessoais do professor, independentemente da instituição a qual este profissional está ligado. Todas as experiências docentes, influenciadas por todas as instituições pelas quais o professor passou e continua passando, fazem parte do seu desenvolvimento profissional. Vejamos agora a justificativa da escolha da Rede Municipal de Ensino como referência para nosso estudo.

\subsection{As professoras da Rede Municipal de Ensino de São Paulo}

A escolha por trabalhar apenas com a Rede Municipal de Ensino de São Paulo surgiu da orientação que recebemos durante o Exame de Qualificação em fevereiro de 2007. As professoras doutoras Paula Perin Vicentini ${ }^{4}$ e Marineide de Oliveira Gomes ${ }^{5}$ consideraram que a pesquisa com duas redes de ensino (municipal e estadual) demandaria esforços e tempo que não teríamos como dar conta num trabalho de mestrado. Frente a isso, elas sugeriram que debruçássemos nossos esforços apenas na Rede Municipal, já que as três professoras que entrevistamos, apesar de terem também lecionado em escolas estaduais, estavam lecionando, no momento da entrevista em 2006, para o Ciclo I do Ensino Fundamental em escolas municipais.

Os critérios que nos ajudaram a convidar as três professoras para participar da pesquisa foram: estar lecionando em 2006 para o Ciclo I do Ensino Fundamental em escolas municipais e ser professoras com diferentes anos de experiências em sala de aula (uma no início, outra no meio e outra na fase final da carreira que apresenta vinte e cinco anos de duração para os profissionais do sexo feminino). Justificamos essa escolha porque ao entrevistar professoras em momentos diferentes da carreira entendemos que conseguimos elementos distintos que favorecem a reflexão sobre o desenvolvimento profissional ao longo desta. Também entendemos que essa escolha permite visualizar momentos distintos da profissão docente: desde as percepções do professor iniciante até as percepções daquele que já acumula bom tempo de experiência profissional. Como já foi dito anteriormente, buscamos em Huberman (2000) e em Tardif (2005) subsídios para nos ajudar a tecer a reflexão sobre a carreira do professor. Diante disso, essa reflexão nos possibilita estudar o percurso do professor na organização escolar, levando em consideração que as características desse

\footnotetext{
${ }^{4}$ Professora Doutora da Faculdade de Educação da USP.

${ }^{5}$ Professora Doutora da Faculdade de Filosofia, Ciências e Letras da USP de Ribeirão Preto.
} 
profissional exercem influência sobre a escola e são, ao mesmo tempo, influenciadas pelo contexto dessa instituição.

Pelo que argumentamos até aqui, entendemos que trabalhar com o relato de professoras dos anos iniciais do Ensino Fundamental, que apresentam diferentes anos de experiência na carreira, nos permite compreender o percurso do desenvolvimento profissional vivido por elas.

As professoras convidadas para participar de nossa pesquisa são: Margareth, com 23 anos de atuação no magistério; Estela, com 14 anos de atuação e Isabela com 3 anos de atuação no magistério público. Mais adiante dissertaremos detalhadamente sobre o percurso profissional e a formação de cada uma delas. Fiquemos, por hora, com os aportes teóricos que fundamentam essa pesquisa.

\section{2 - O referencial teórico}

Trabalhar com as percepções de professoras sobre seu cotidiano, seus modos de agir, de refletir, de buscar bases para sua atuação profissional, coloca-nos o imperativo de realizar esse intento em parceria estreita com suas realizadoras. São elas que delimitam o caminho e o modo do seu caminhar profissional. Portanto, nossa preocupação principal é trazer para o primeiro plano o que as professoras entendem a respeito de sua própria construção enquanto profissionais. Na busca de aproximação com o vivido por elas, optamos por tentar captar as percepções delas sobre a profissão docente por meio da oralidade. Para tanto, acreditamos que a História Oral se apresenta como um referencial profícuo para a compreensão da visão dos sujeitos sobre a profissão e os modos de ser e de se estar nela.

Outro referencial que nos orienta nessa jornada é a problematização do percurso de vida profissional como alicerce para compreendermos como, ao longo dos anos da carreira, as professoras foram construindo suas práticas. $\mathrm{O}$ estudo do percurso de vida profissional, que tem como um dos principais expoentes Huberman (2000), oferece subsídios para verificar como as professoras foram desenvolvendo sua profissionalidade desde o momento em que iniciaram na profissão até os dias de hoje.

Os referenciais teóricos da História Oral e do percurso de vida profissional foram escolhidos porque se mostraram adequados para ajudar na compreensão de aspectos importantes da profissão docente e do desenvolvimento profissional. 


\subsection{História Oral}

Ao convidarmos três professoras, em momentos distintos da carreira do magistério, para relatarem suas experiências acerca da profissão docente e dos seus modos de ser e estar nela, partimos do princípio de que esses relatos não se restringem

a uma história de vida, a um único relato,ou a um único depoimento; trabalhando com relatos de vários indivíduos de uma mesma coletividade,[a história oral] abre a possibilidade de leitura do social, através de múltiplas versões individuais, permitindo reconstruir, através de vários relatos, a história estrutural e sociológica de determinados grupos, reconstituir a trajetória de um grupo social (LANG, 1996, p. 45).

Baseando-nos então na idéia de Lang explicitada acima, de que o trabalho com o relato de vários indivíduos contribui para o entendimento da trajetória de um grupo social, buscamos, com nossas três entrevistadas, reconstituir o percurso profissional delas na carreira do magistério público paulista,que para as mulheres tem duração de vinte e cinco anos. Teremos então um panorama dos elementos marcantes na vida profissional dessas três professoras. Sabemos que um número maior de entrevistadas nos possibilitariam, como coloca Lang, o acesso a uma multiplicidade de versões. No entanto, optamos por trabalhar com os depoimentos de apenas três professoras em razão do caráter iniciante de uma pesquisa de mestrado, bem como da restrição de tempo para conclusão desse estudo.

A opção por esse método de análise também se deve às considerações de Meihy $(2005,45)$ :

Seria um erro usar projetos de história oral como se fossem estudos de casos. Por se tratar de situações de vínculos com múltiplos aspectos da vivência coletiva, as vidas contempladas e os temas analisados não podem ser reduzidos a exemplos de situações específicas.

Acreditamos que o modo de ser professor, particular de cada um, resulta da estreita combinação entre as características, posicionamentos e experiências pessoais e os múltiplos aspectos intervenientes na produção da escola, da profissão docente e do cotidiano escolar de um modo geral. Daí não considerarmos este um estudo de caso. Consideramos essa pesquisa como um estudo de cunho qualitativo pautado na História Oral. À medida que estudos quantitativos buscam seguir com rigor um plano previamente estabelecido, a pesquisa qualitativa costuma ser direcionada ao longo de seu desenvolvimento. A pesquisa qualitativa não visa enumerar ou mesurar eventos; seu foco de interesse é amplo e parte de uma perspectiva onde os dados são colhidos de uma 
forma descritiva mediante contato direto com os sujeitos envolvidos nas situações que se pretende investigar. Esse contato, no nosso caso, se deu através de entrevistas realizadas com os sujeitos da pesquisa. Neste tipo de pesquisa, procuramos compreender um fenômeno ' $\mathrm{x}$ ' segundo a perspectiva da participação dos sujeitos envolvidos para poder, a partir daí, situar nossas interpretações em relação ao fenômeno estudado. Nessa pesquisa, o fenômeno é o desenvolvimento profissional como chave para entender os modos de ser professor na escola pública contemporânea e os sujeitos envolvidos são as próprias professoras.

Para a compreensão do desenvolvimento profissional se faz necessário que levemos sempre em consideração que os saberes profissionais destas professoras são inseparáveis das suas próprias experiências de vidas. Desde quando foram alunas, elas iniciaram a aquisição de seus primeiros modelos de ensino e, ao longo da carreira, estão desenvolvendo, recriando e transformando esses modelos. Elas são, portanto, as pessoas mais indicadas para falar sobre a profissão docente. As professoras carregam em si traços ou influências das teorias sobre essa profissão e muito de prática acumulada durante os anos da docência.

Ao privilegiarmos a voz das professoras na busca por compreender o seu papel profissional contemporâneo, nos apoiamos em Goodson (1992 apud CATANI, 1997, p. 20) que é um árduo defensor da importância de se colocar a voz do professor nos estudos da profissão, da história da escola e do ensino e das propostas de intervenção pedagógica. Para o autor britânico, o conhecimento que se produz a partir da voz dos professores sobre seus pensamentos e sobre suas práticas contribuem no entendimento mais profícuo das reais condições de trabalho destes profissionais. $\mathrm{O}$ depoimento do sujeito diretamente envolvido no processo do fenômeno que se busca analisar é de vital significado para a compreensão deste fenômeno. Em outras palavras, o relato das professoras da Rede Municipal de Ensino de São Paulo traz o olhar de quem tem vivenciado a experiência de ser professora nesta rede tão complexa e em outras redes também e proporciona a depreensão de como a profissão docente está sendo produzida a partir de toda essa experiência vivenciada por cada professor.

O inglês Paul Thompson (1998, p. 179), outro grande historiador da oralidade, coloca que a História Oral e, por conseguinte, o trabalho com a memória, oferecem recompensas inesperadas para o historiador que esteja preparado para apreciar a complexidade com que a realidade e o mito, o "objetivo' e o 'subjetivo', se 
mesclam inextricavelmente em todas as percepções que o ser humano tem do mundo, individual e coletivamente.

São justamente essas percepções, individuais e coletivas, objetivas e subjetivas, que o professor tem do mundo que o cerca e especificamente da sua profissão, que nos interessam nessa pesquisa. A experiência vivida configura-se um amálgama dessas percepções: subjetiva-objetiva e individual-coletiva. Essas percepções, embora diversas, contribuem para formar um todo: a experiência vivida. E é a partir das percepções das professoras que buscamos subsídios para compreender a profissão docente na atualidade. A experiência individual carrega muito da experiência coletiva e vice-versa. Tentar separar estas duas faces da mesma moeda é, no mínimo, incoerente. Thompson (1998, p. 121) também coloca que outra grande qualidade do uso da História oral é a riqueza de informação que se pode obter através dela. Partindo dos estudos deste autor, entendemos que essa riqueza está justamente na impossibilidade de se separar a vivência individual da vivência coletiva, daí a relevância dessa teoria no auxílio da compreensão de fenômenos complexos como, por exemplo, os modos de ser professor na escola pública contemporânea.

Outra referência que nos ajuda a sustentar a opção de lançarmos mão de fontes orais para a compreensão da profissão docente está presente nos estudos de Meihy (2005). Este autor coloca que a História Oral é um recurso moderno, usado para a elaboração de documentos, arquivamento e estudos referentes à experiência social de pessoas e de grupos. No nosso caso, ela é um recurso para aprofundarmos os estudos e o conhecimento sobre a profissão docente. Esse mesmo autor também coloca que, como pressuposto, a história oral implica uma percepção do passado como algo que tem continuidade hoje e cujo processo histórico não está acabado (MEIHY, 2005, p. 19). Assim é também com a profissão docente, fruto do modo como cada professor a interpreta e a produz. Em outras palavras, cada professor, desde o momento em que se tornou aluno e depois quando desenvolveu sua formação, foi adquirindo e construindo conhecimentos e representações acerca da profissão docente e continua elaborando esses conhecimentos e representações ao longo da carreira, num movimento contínuo e incessante. Cada professor tem então uma percepção da profissão desde o momento em que entra na carreira, e esta percepção vai sofrendo modificações por conta do processo de desenvolvimento profissional vivido por cada um.

Ainda nessa linha de raciocínio, é necessário ter em mente, como bem afirma Meihy (2005, p. 56), que 
toda narrativa é sempre e inevitavelmente construção, elaboração, seleção de fatos e impressões. Portanto, como discurso em eterna elaboração, a narrativa para a história oral é uma versão dos fatos e não os fatos em si. Convém lembrar que, por mais parecidas que sejam as narrativas dos mesmos fatos, cada vez que são reditas carregam diferenças significativas.

A história oral coloca a necessidade de se estabelecer que a versão dos fatos não é os fatos em si. E é aí que reside nosso principal ponto de interesse: entender qual é a versão que as professoras nos dão sobre suas relações com a vida profissional desenvolvidas ao longo de suas carreiras. Somente a voz de quem exerce a docência na escola contemporânea pode nos dizer o que isso significa.

Encontramos em Louro (1991 apud GUSMÃO, 2004, p. 31) a explicitação de alguns méritos propiciados pelo uso dessa estratégia analítica em estudos sobre educação. Segundo seus estudos, a história oral, aplicada à educação, pode iluminar lugares ocultos da vida escolar, apontar formas sutis de resistência e sublinhar os efetivos de currículos, normas e diretrizes. O professor ganha relevo porque sua voz (seu relato) se torna o principal documento analisado, o que permite resgatar as conquistas, os dilemas e as aspirações dos docentes. Gusmão (2004, p. 31), continuando na defesa do uso da História Oral, diz que

o registro de experiências de professores, as descrições da maneira como foram vivenciadas as reformas educacionais, $e$ a relação estabelecida com a instituição escolar - seja como alunos seja como professores - deslocam o enfoque, tradicionalmente centrado nas políticas públicas e nas filosofias pedagógicas.

É exatamente essa abertura para se deslocar o enfoque centrado nas políticas públicas e nas filosofias pedagógicas que permite trazer o foco para o que pensam os professores sobre o seu fazer no cotidiano da escola. É esse nosso interesse na presente pesquisa.

\subsection{Percurso profissional: a carreira vista a partir da história de vida}

Como vimos anteriormente, a História Oral possibilita verificar quais são as percepções das professoras sobre a experiência vivida na carreira docente, sobre o processo de desenvolvimento profissional e sobre como este influencia na elaboração dos modos de ser e de estar na profissão porque assume o relato dos sujeitos envolvidos num dado contexto como fonte relevante de informação sobre esse contexto. Essa fonte, que tem como pressuposto a oralidade, nos revela dimensões da experiência vivida por 
determinados sujeitos que, talvez, não fosse possível revelar por outro tipo de fonte, como por exemplo, a documental material. Como bem nos diz Moita (2000, p. 117), a abordagem biográfica é neste caso mais do que uma metodologia coerente com a problemática construída. É a via de acesso á sua exploração. Dito de outro modo, não seria possível conhecer a percepção dos professores sobre seus modos de produzir a profissão senão a partir do relato dos mesmos. Um documento oficial, produzido por algum especialista da Secretaria de Educação não daria conta de apresentar o olhar dos docentes sobre sua carreira porque partiria de outras fontes que não seriam a voz dos professores. Entendemos que os professores são os sujeitos mais indicados a falar sobre como é ser professor na escola pública contemporânea. Ninguém pode fazer isso por eles, daí a importância de deixar os professores falarem e de respaldar nossa pesquisa na História Oral.

Ao lado da História Oral, buscamos apoio teórico nos estudos sobre a carreira do professor para que fundamentar nossa reflexão sobre o seu percurso profissional a fim de compreender como ocorre o desenvolvimento profissional.

Um dos autores que trabalha com a perspectiva da carreira docente é Huberman (2000). Este autor é herdeiro dos estudos da Escola de Chicago que restauraram a metodologia da História Oral como epistemologia que permite interpretar dados biográficos de forma qualitativa. Ele busca, em seus estudos, compreender melhor o destino profissional dos professores, bem como as determinantes desse destino. Nesse aspecto, o objeto do nosso trabalho de mestrado - o desenvolvimento profissional de professores - está presente nos estudos do autor suíço porque este ao lidar com os ciclos de vida profissional está lidando, também, com a questão do desenvolvimento profissional. Segundo Huberman, o modo como o professor se coloca e age diante das situações que vivencia durante a carreira configura-se em fases que demonstram o nível de experiência que ele já adquiriu.

Os professores estudados por Huberman pertenciam à classe de professores do ensino secundário e a uma carreira docente com quarenta anos de duração. Este autor elaborou cinco fases para a carreira do professorado que ele pesquisou na Europa. Essas fases estão expressas na tabela 5: 
TABELA 5 - Fases da Carreira segundo Huberman (2000, p. 47)

\begin{tabular}{|c|l|}
\hline ANOS DE CARREIRA & FASES / ESTAPAS \\
\hline $1-3$ & Entrada \\
\hline $4-6$ & Estabilização (consolidação de um repertório pedagógico) \\
\hline $7-25$ & Diversificação (ativismo - questionamento) \\
\hline $25-35$ & Serenidade (distanciamento afetivo - conservantismo) \\
\hline $35-40$ & Desinvestimento (sereno ou amargo) \\
\hline
\end{tabular}

Sobre as fases, Huberman (2000, p. 37) não garante que tais seqüências sejam vividas sempre pela mesma ordem, nem que todos os elementos de uma dada profissão as vivam todas. Ele acredita que haja uma tendência em se agir de determinada forma num determinado período da carreira de acordo com a experiência e com o conhecimento que o sujeito possui.

Não aprofundaremos a reflexão sobre as fases apontadas por Huberman porque o que nos interessa nos estudos deste autor é sua constatação sobre a carreira do professor ser um terreno fértil para a investigação do desenvolvimento profissional docente. Também não teríamos como fazer um paralelo entre a situação profissional das professoras da Rede Municipal de Ensino de São Paulo e dos professores estudados pelo autor suíço porque há profundas diferenças quanto aos contextos dessas duas situações profissionais como, por exemplo, a duração das carreiras: em São Paulo são vinte e cinco anos de carreira para a professora e no contexto estudado por Huberman são quarenta.

Assim como Huberman, nós também pretendemos investigar o percurso profissional docente numa determinada instituição - a escola. Mas, ao contrário do caminho seguido pelo autor suíço, não utilizaremos fases durante nossa análise do percurso profissional das professoras entrevistadas porque entendemos que $\mathrm{o}$ desenvolvimento profissional é um processo e não uma série de fases que precisam ser alcançadas de acordo com os anos de experiência.

O espanhol Marcelo Garcia (1994), partindo dos estudos de Huberman y Schapira, também concorda com a existência do ciclo de vida dos professores e com a formulação de diferentes etapas da vida profissional. Ele diz que essas etapas não são regras fixas e que podem ou não ocorrer porque existem influências pessoais, profissionais e contextuais que atingem diretamente os professores. São essas influências pessoais, profissionais e contextuais que buscamos compreender para tentar 
elaborar uma análise sobre como é ser professor na escola pública contemporânea sem levar em consideração as etapas da vida profissional colocas por esse autor.

Outro estudo nessa linha foi realizado por Cavaco (1995). Esta autora investigou a trajetória de vida pessoal e profissional de vários professores portugueses, de diferentes idades e anos de experiências no magistério secundário. Cavaco defende a idéia de que os saberes profissionais são adquiridos através da experiência e que a identidade profissional do professor é construída num processo de socialização centrado na escola, mediante apropriação de conhecimentos profissionais que vêm da prática e interiorização de normas e valores reguladores das ações do professor.

Gonçalves (2000) realizou uma pesquisa com professoras do ensino primário em Portugal. Nessa pesquisa, o autor teve como objetivo estudar a carreira dessas professoras, numa perspectiva de formação e desenvolvimento profissional. Para tanto, ele detectou características definidoras dos percursos profissionais das professoras portuguesas e identificou momentos significativos desses mesmos percursos. Ele, assim como Huberman (2000), trabalha com a idéia de fases ou etapas da carreira. O que nos interessa em seus estudos é o tratamento que este autor dispensa à questão do desenvolvimento profissional de professoras do ensino primário na perspectiva da carreira. Para ele o desenvolvimento profissional, mais do que outros aspectos do desenvolvimento do indivíduo, é condicionado pelos fatores de contexto, podendo acontecimentos de natureza sociopolítica e cultural vir a alterá-lo ou, mesmo, a determiná-lo (GONÇALVES, 2000, p. 148).

O que Huberman (2000), Marcelo Garcia (1994), Cavaco (1995) e Gonçalves (2000) têm em que comum é o fato de que esses autores, de uma forma ou de outra, consideram a carreira do professor como fonte para a investigação do desenvolvimento profissional docente. Além disso, todos eles, independentemente da metodologia utilizada, lançam mão de histórias de vida como aportes para o entendimento do percurso profissional de cada professor. Nossa pesquisa se insere também nesse contexto de tomar a carreira docente e as histórias de vida profissional como ponto de partida para o entendimento do desenvolvimento profissional das professoras por nós entrevistadas.

\section{3 - O caminho metodológico}

Pelas considerações tecidas até aqui sobre o entendimento da carreira docente como possibilidade de investigação do percurso profissional de cada professor, 
reforçamos que a pesquisa que realizamos se insere no conjunto dos estudos qualitativos que têm por opção metodológica o trabalho com as histórias de vida através dos subsídios da História Oral.

Como já dissemos em outro momento desse texto, as professoras doutoras Paula Perin Vicentini e Marineide de Oliveira Gomes nos orientaram, no momento do exame de Qualificação em fevereiro de 2007, a adotarmos como referência para nosso estudo apenas o contexto da Rede Municipal de Ensino para a análise das entrevistas que realizamos com três professoras em 2006 e em 2007.

No segundo semestre de 2006, convidamos três professoras com diferentes anos de experiência no magistério para serem colaboradoras dessa pesquisa. $\mathrm{O}$ critério 'diferentes anos de experiência' se refere à tentativa de compreensão do desenvolvimento profissional desde o momento em que a professora está entrando na carreira até o momento em que ela está próxima do seu encerramento. Como ocorre o processo de desenvolvimento profissional da professora ingressante, da professora que já tem mais de uma década de experiência no ensino e da professora que possui um pouco mais de duas décadas de experiência numa carreira que apresenta vinte e cinco anos de duração?

Como a carreira do magistério comporta vários níveis de ensino e professoras com diferentes percursos formativos, delimitamos, para esta pesquisa, que as professoras estivessem lecionando no ano de 2006 para o Ciclo I do Ensino Fundamental da Rede Municipal de Ensino, e que elas tivessem formação em nível superior, além da formação em nível médio para o magistério. Uma pesquisa patrocinada pelo IIPE/UNESCO ${ }^{6}$ intitulada "O perfil dos Professores Brasileiros: o que fazem, o que pensam, o que almejam..." aplicou questionários que foram respondidos por 5000 docentes de escolas públicas e privadas das vinte e sete Unidades da Federação. Segundo os dados dessa pesquisa (PESQUISA NACIONAL UNESCO, 2004), dentre os professores brasileiros, 81,3\% são mulheres e 18, 6\% são homens. [...] Cabe ressaltar que a maioria das professoras encontra-se atuando no ensino fundamental. Esses dados ajudam a justificar a escolha por trabalhar com professoras do Ciclo I do Ensino Fundamental.

\footnotetext{
${ }^{6}$ Instituto Internacional de Planeamiento de La Educación/Organização das Nações Unidas para a Educação, a Ciência e a Cultura.
} 
Diante desses critérios, convidamos Isabela (3 anos de experiência), Estela (14 anos de experiência) e Margareth (23 anos de experiência) a concederem entrevista sobre seus percursos profissionais e elas aceitaram.

A opção por trabalhar com entrevistas semi-estruturadas e recorrentes, tendo como aporte teórico a História Oral, coloca essa pesquisa no conjunto dos trabalhos de caráter qualitativo. As entrevistas semi-estruturadas foram realizadas no segundo semestre de 2006 e as entrevistas recorrentes foram colhidas no primeiro semestre de 2007.

Entendemos como entrevista semi-estruturada aquela na qual os pesquisadores constroem um roteiro que os orienta durante a realização da entrevista. Para Bogdan \& Biklen (1994, p. 135), a utilização das entrevistas semi-estruturadas nos fornece a certeza de podermos obter dados comparáveis entre os vários sujeitos entrevistados. Já a entrevista recorrente (LEITE \& COLOMBO, 2006) refere-se à possibilidade que o sujeito pesquisador tem de voltar ao sujeito pesquisado para rever alguns pontos da primeira entrevista que ou não ficaram muito esclarecidos ou necessitaram de complemento. Como durante o exame de Qualificação ficou clara a necessidade de voltarmos às professoras entrevistadas para preencher algumas lacunas presentes nas entrevistas de 2006, esse recurso metodológico mostrou-se adequado ao desenvolvimento de nossa pesquisa.

As entrevistas foram registradas em aparelho de gravador de áudio com o uso de fitas K7 e transcritas integralmente, tarefa que não se mostrou nada simples. Sobre isso, Marcuschi (2001, p. 53) alerta que:

a tarefa da transcrição não é algo simples, nem natural. Trata-se de uma atividade que atinge de modo bastante acentuado a fala original e pode ir de um patamar elementar até uma interferência muito grande. Não existe uma fórmula ideal par a transcrição 'neutra' ou pura, pois toda transcrição já é uma primeira interpretação na perspectiva da escrita.

Durante a dissertação, as falas das professoras que utilizamos foram editadas para que pudesse ser feita a limpeza de expressões típicas da oralidade para a norma escrita padrão. Marcuschi (2001) chama essa edição das falas de textualização. Segundo ele, esse processo de textualização consiste em eliminar dos discursos dos sujeitos entrevistados, de maneira consciente, as marcas conversasionais como hesitações, repetições, auto-correções, etc. A edição das falas buscou preservar o sentido original das mesmas. 
O leitor perceberá que as falas das professoras Isabela, Estela e Margareth foram usadas durante todo o texto da dissertação como suporte empírico para as reflexões que tecemos.

Outra questão metodológica que se faz presente nessa dissertação diz respeito ao levantamento de categorias de análise para a compreensão do desenvolvimento profissional das professoras. Durante o exame de Qualificação foi sugerida a utilização de três categorias para estruturarmos a análise dos dados colhidos nas entrevistas em 2006 e em 2007: a relação com o conhecimento, a autonomia e a avaliação. No entanto, optamos por desconsiderar a categoria avaliação e por acrescentar a categoria formação contínua. Entendemos que relação com o conhecimento, autonomia e formação contínua são elementos de um mesmo processo que nos ajudam a compreender o desenvolvimento profissional docente de forma clara e concatenada. Essas categorias constituem um meio de classificar os dados descritivos, recolhidos por meio das entrevistas, de forma que o material contido num determinado tópico possa ser fisicamente apartado dos outros dados (BOGDAN \& BIKLEN, 1994, p. 221). Em outras palavras, ajudam a agrupar os temas em comum, presentes nos relatos das professoras a fim que possamos tecer uma análise do processo de desenvolvimento profissional de cada uma delas. 
CAPÍtulo 2 - a Rede Municipal de

Ensino de São Paulo 
Neste capítulo dedicaremos nossa atenção ao contexto da Rede Municipal de Ensino de São Paulo. Quais são as especificidades desse contexto? O que faz com que a situação dos professores paulistanos seja referência para nosso estudo?

\section{1 - Origem da Rede Municipal de Ensino}

Antes de nos determos na situação dos professores, vejamos como surgiu a Rede Municipal de Ensino de São Paulo. Souza (2005) nos coloca que a primeira Escola de Ensino Primário da Rede Municipal foi fundada em 1956 e chamava-se Grupo Municipal de Ensino Primário do Jaçanã. Até esta data, o município organizava e gerenciava os Parques Infantis que ofereciam atividades de Educação Infantil para uma parcela ínfima da população da cidade e realizava convênios com o Estado para que este ofertasse o ensino primário. Também em 1956 foram criados os cem primeiros cargos de professores primários. Hoje esses professores recebem a denominação de Professores de Ensino Fundamental I, o que corresponde aos primeiros quatro anos do Ensino Fundamental - antigo Ensino Primário.

Essa autora traz a informação de que em 1959 foi instituído o Ensino Municipal de Ciclo Secundário (curso ginasial) na cidade de São Paulo. Ainda na década de 50 a Rede Municipal já oferecia o curso primário e o curso ginasial. Em 1968, antecipando-se à LEI 5692/71, que implanta a escola fundamental de oito anos, São Paulo já contava com oito anos para os estudos básicos. A Rede cresce junto com o ritmo acelerado das transformações da cidade.

A dissertação de Souza nos permite ainda vislumbrar a complexidade da Rede Municipal de Ensino de São Paulo. Se em 1956 a rede contava (atendendo somente o Ensino Primário) com

100 professores, 100 classes e aproximadamente 4.000 alunos, ela tem, em 2004, 14.731 professores do Ensino Fundamental I (antigo primário - 1. A 4 $4^{a}$. Séries), 16.365 do Ensino Fundamental II (antigo curso ginasial $-5^{a}$. A 8 . Séries), totalizando 31.096 docentes trabalhando no Ensino Fundamental ( $1^{a}$. A $8^{a}$. Série).

São ao todo 52.258 professores [educação infantil, fundamental $e$ médio] atuando na Rede Municipal de Ensino de São Paulo, 1.618 Coordenadores Pedagógicos, 1.121 Diretores de Escola, 256 Diretores de Equipamento Social, 252 Supervisores, 928 Assistentes de Direção. Conta ainda com Agentes Escolares, Auxiliares Técnicos Administrativos I e II, totalizando 73.729 profissionais atuando nas Escolas Municipais e nos Centros de Educação Infantil, atendendo a mais de um milhão (aproximadamente 1.200.000) de crianças, adolescentes, jovens e adultos (SOUZA, 2005, p. 36-37). 
Em menos de cinqüenta anos o número de matrículas e de cargos docentes aumentou vertiginosamente. Esse aumento acompanhou o crescimento da cidade. A Rede Municipal é uma rede gigante em se tratando de município e como toda grande rede tem seus dilemas e suas especificidades. Uma dessas especificidades é o corpo docente. Sobre isso Souza (Ibid, p. 55) nos diz que

o número de professores que atuam na rede municipal de ensino de São Paulo em 2004 é de 52.258. São 45.145 professores efetivos (aprovados no concurso público) e 7.113 professores não efetivos - professores comissionados, admitidos, estáveis, contratados. A maioria tem o curso superior. Geralmente moram no mesmo bairro em que a escola está localizada ou em bairros próximos. A heterogeneidade do grupo está explícita nas diferentes idades, religiões, etnias, militância partidária, política, preferências culturais, artísticas, enfim pela história de vida, também marcada pelos anos que estão exercendo a profissão. Alguns esperam a publicação da aposentadoria, outros são recém-ingressantes na rede, outros estão com 5, 10, 15 anos de experiência, ou seja, compõem um grupo intermediário: nem estão iniciando nem terminando o exercício da profissão docente. Geralmente acumulam cargos no próprio município ou na rede estadual, alguns casos em escolas particulares, o que intensifica a jornada de trabalho chegando de 10 a 12 horas diárias.

Diante de todas essas variáveis apresentadas no excerto acima percebemos que não era viável trabalhar com o professor da Rede Municipal de Ensino de São Paulo de forma genérica, ou seja, abarcando todos os níveis de ensino oferecidos. Por esse motivo, buscamos uma maneira de estudar os modos de ser professor na escola pública municipal de São Paulo como referência que possibilitasse compreender um fenômeno maior - o desenvolvimento profissional - dentro do contexto da profissão docente. Como já foi dito anteriormente, direcionamos nossos esforços de compreensão para histórias das professoras efetivas (titulares ou adjuntas ${ }^{7}$ ) que estivessem atuando nos primeiros anos do Ciclo I do Ensino Fundamental no ano de 2006. Esse direcionamento ocorreu ao refletirmos sobre as diferenças entre os professores polivalentes do Ciclo I e os professores especialistas do Ciclo II do Ensino Fundamental. Sobre isso, Barreto e Mitrulis (2001, p. 130) mostram que há certa distinção entre os professores das primeiras e os das últimas séries do ensino fundamental. Tal distinção se dá no plano da formação profissional, do regime de trabalho, das teorias adotadas para

\footnotetext{
${ }^{7}$ O professor efetivo da Rede Municipal de Ensino de São Paulo se enquadra em duas categorias: os titulares (que são lotados nas escolas) e os adjuntos (que são lotados nas Coordenadorias de Educação).
} 
fundamentar as práticas e da visão da função social da escola. Enquanto os primeiros, de formação polivalente, passaram nas últimas décadas por um processo mais intenso de iniciação a teorias que fortalecem uma concepção de educação mais integradora presente nos ciclos, os professores das 5.as às 8as. séries, especialistas nas diferentes áreas do conhecimento, embora comunguem o mesmo ideário de educação democrática e função social da escola, mantêm um forte compromisso com o conteúdo de suas disciplinas. Eles costumam resistir mais ao que supõem ser um risco de degradação dos padrões de qualidade de ensino e freqüentemente encontram muita dificuldade de trabalhar com uma concepção de educação que leve em conta o aluno na sua totalidade, a qual se viabiliza particularmente em condições de trabalho coletivo.

Portanto, quando falamos em desenvolvimento profissional e modos de ser professor, estamos nos referindo diretamente aos professores - e no nosso caso, às professoras - que trabalham com os quatro anos iniciais do Ensino Fundamental.

A rede municipal de ensino é a principal responsável pelo atendimento de crianças de 0 a 3 anos no CEI (Centro de Educação Infantil), de crianças de 3 a 6 anos na EMEI (Escola Municipal de Educação Infantil) e de crianças de 6 a 14 anos na EMEF (Escola Municipal de Ensino Fundamental). Esta rede também oferece - em menor quantidade - o Ensino Médio em escolas denominadas EMEFM (Escola Municipal de Ensino Fundamental e Médio). Em toda a rede há apenas oito escolas que oferecem, junto com o Ensino Fundamental, o Ensino Médio. Dessas oito escolas, quatro também oferecem cursos técnicos de contabilidade, administração, secretariado, etc. Há uma Escola Técnica do Sistema Único de Saúde que tem suas vagas destinadas a servidores do Sistema Único de Saúde do Município.

A Secretaria Municipal de Educação também administra três CECIs (Centro de Educação e Cultura Indígena) que atende aldeias da zona norte e da zona sul de São Paulo. Nesses CECIs a educação formal acontece associada à preservação da cultura e da língua dos povos indígenas da região. Esta Secretaria também tem se empenhado em promover a Educação de Jovens e Adultos. Esta modalidade de ensino é oferecida em algumas EMEFs e também em um centro próprio: Centro Integrado da Educação de Jovens e Adultos - CIEJA. Há 15 CIEJAs em toda a cidade. O município é responsável apenas pela formação de Jovens e Adultos no Ensino Fundamental. A formação em nível médio é de responsabilidade da Secretaria Estadual de Educação.

O tamanho da rede municipal impressiona ${ }^{8}$. Vamos aos números:

334 Centros de Educação Infantil (CEI);

${ }^{8}$ Dados extraídos de www.portaleducacao.prefeitura.sp.gov.br. Acessado em Março de 2007. 
464 Escolas Municipais de Educação Infantil (EMEI);

457 Escolas Municipais de Ensino Fundamental ${ }^{9}$ (EMEF);

15 Centros Integrados da Educação de Jovens e Adultos (CIEJA);

3 Centros de Educação e Cultura Indígena (CECI);

21 Centros Educacionais Unificados (CEU).

A entrega em 2003 dos 21 Centros Educacionais Unificados - na gestão da prefeita Marta Suplicy, do Partido dos Trabalhadores - trouxe inovações culturais e escolares para a cidade de São Paulo. O CEU é um complexo educacional que abriga um CEI, uma EMEI, uma EMEF, playground, teatro, cinema, biblioteca, quadras de esportes, piscinas, vestiários, ateliês, estúdios para oficinas de vídeo, $\mathrm{TV}$, rádio e fotografia, telecentro (centro de informática), pista de skate e área verde. Os CEUs proporcionam educação, esporte, cultura, lazer e aulas de informática em um mesmo local. O projeto oferece formação em recursos educativos e cultural integrados com a realidade da comunidade e direcionada para toda a família. A atual gestão do prefeito Gilberto Kassab, do DEM, modificou alguns pontos da estrutura do CEU e deu início à construção de mais Centros Educacionais Unificados, que serão entregues até o final de seu governo em 2008.

Hoje as escolas da Rede Municipal de Ensino de São Paulo administrada pela Secretaria Municipal de Educação (SME) - estão organizadas em treze Coordenadorias de Educação. Cada Coordenadoria é responsável por escolas de vários bairros. Por exemplo, a Coordenadoria de Educação de Guaianases (que fica na zona leste da cidade) abriga escolas do bairro de Guaianases e dos bairros vizinhos a Guaianases, como, por exemplo, Inácio Monteiro, Barro Branco, Prestes Maia, Cidade Tiradentes, etc. As Coordenadorias de Educação são instâncias descentralizadas da Secretaria Municipal de Educação que administram as escolas pelas quais são responsáveis. Cada Coordenadoria possui certa autonomia de gestão desde que cumpram as normas e diretrizes propostas pela SME. Essas normas e diretrizes dizem respeito ao funcionamento das Unidades Escolares, à vida funcional dos servidores públicos municipais em Educação e aos programas pedagógicos que orientam a ação dos professores, como, por exemplo, o Programa Ler e Escrever ${ }^{10}$.

\footnotetext{
${ }^{9}$ Dentre essas 457 EMEFs, oito também oferecem o Ensino Médio.

${ }^{10}$ O Programa Ler e Escrever determina como prioridade para o Ensino Fundamental o desenvolvimento da escrita e da leitura.
} 
A Rede acolheu, até março do ano de $2006^{11}, 392.515$ alunos na Educação Infantil, 686.996 alunos no Ensino Fundamental e 3.008 alunos no Ensino Médio. Mais de um milhão de alunos são atendidos todos os dias nas Unidades Escolares da Rede Municipal.

Para atender tantos alunos são necessários muitos professores. $\mathrm{Na}$ Educação Infantil são 18.559 professores efetivos e 597 não efetivos. No Ensino Fundamental I (quatro primeiros anos) são 12.681 professores efetivos e 1.219 não efetivos. No Ensino Fundamental II (quatro últimos anos) são 14.162 professores efetivos e 771 não efetivos. No Ensino Médio são 94 professores efetivos e 27 não efetivos. Esses dados encontram-se na tabela abaixo:

TABELA 6 - Situação dos Professores - Rede Municipal de Ensino de São Paulo

\begin{tabular}{|l|c|c|c|}
\hline \multicolumn{1}{|c|}{ 2006 } & Prof. Efetivos & Prof. Não Efetivos & Total \\
\hline Educação Infantil & 18.559 & 597 & 19.156 \\
\hline Ensino Fundamental I & 12.681 & 1.219 & 13.900 \\
\hline Ensino Fundamental II & 14.162 & 771 & 14.933 \\
\hline Ensino Médio & 94 & 27 & 121 \\
\hline TOTAL GERAL & 45.496 & 2.614 & 48.110 \\
\hline
\end{tabular}

Dados Educacionais Gerais até março de 2006

Os Professores Efetivos são aqueles que foram aprovados em concursos públicos de provas e títulos. Os Não Efetivos são professores que adquiriram direitos mesmo sendo eventual, comissionado, designado, contratado, etc. Dentre os Professores Efetivos existem os Titulares e os Adjuntos. A vida dos Professores Adjuntos não é muito fácil porque eles podem ser obrigados a mudar de escola todos os anos e, inclusive, mudar de escolas num mesmo ano. Os Professores Adjuntos são professores substitutos que são concursados e que assumem salas de professores em férias, em licença, em designação em outro cargo, etc. Os Professores Titulares só mudam de escola por escolha própria num processo que acontece todo ano, chamado de Remoção. O processo de Remoção permite que os professores possam escolher outra escola para trabalhar. Essa escolha acontece sempre no segundo semestre e vale a partir do próximo

\footnotetext{
${ }^{11}$ Cf. Dados Educacionais Gerais extraídos de http://portaleducacao.prefeitura.sp.gov.br/. Acessado em março de 2007.
} 
ano letivo. A maioria dos professores que entram em processo de remoção visa a trabalhar em escolas que estejam mais próximas de suas residências.

Em virtude do que foi apresentado acima, a especificidade da Rede Municipal de Ensino de São Paulo se coloca na sua própria origem: a Rede surgiu junto com o crescimento acelerado da cidade. A Escola Primária passou a ser uma necessidade tão urgente da cidade de São Paulo que as poucas Escolas Primárias geridas pelo Governo do Estado não deram conta de abarcar a demanda que se fez presente na década de 50 do século XX. A partir da criação do Grupo Primário de Ensino do Jaçanã em 1956, a Rede Municipal de Ensino se expandiu de tal forma que hoje, cinqüenta e um anos depois, contamos com uma das maiores redes de ensino do país com mais de um milhão de alunos e quase cinqüenta mil professores.

\section{2 - Os Ciclos e a Rede Municipal de Ensino de São Paulo}

A opção por pesquisar os modos de ser professor junto a professores que atuam na Rede Municipal leva-nos diretamente à questão dos ciclos, inovação educacional implantada na Rede em 1992. Antes de aprofundarmos a discussão sobre os ciclos em São Paulo, vejamos um resgate histórico da problemática dos ciclos no Brasil.

Já no início do século XX havia uma preocupação com a reprovação dos alunos. Sampaio Doria foi um dos primeiros educadores que se dedicou à questão de procurar alternativas para a reprovação. Knoblauch (2003) nos diz que este educador propôs um projeto de reforma que ficou conhecido como Reforma Sampaio Doria. Esta reforma tomou caráter de Lei em 1920. Sampaio Doria não apresentou uma proposta de ciclo, mas propôs a não reprovação do $1^{\circ}$. para o $2^{\circ}$. Ano. Segundo Knoblauch a alternativa que este educador buscava para a reprovação tinha interesses diretos com a modernização do país e a reprovação seria um empecilho a essa modernização.

Apesar desse primeiro esforço de se repensar a questão da reprovação, mesmo que com interesses além do pedagógico, nada mudou na instrução pública. $\mathrm{O}$ tema da reprovação só voltou a ser debatido na década de 50 com Almeida Júnior. Este educador propôs a progressão automática e ressaltou que a reprovação representava, entre outras coisas, prejuízos aos cofres públicos. Segundo Knoblauch (2003), os idealizadores da progressão automática trouxeram a questão de que para que ela funcionasse seria necessário realizar mudanças no currículo, na forma de avaliação e no preparo do professor. 
A partir da década de 50 do século XX, algumas propostas de alternativas para a reprovação começaram a aparecer. Barreto e Mitrulis (2001, p. 106) mostram que o estado do Rio Grande do Sul deu os primeiros passos nesse sentido adotando em 1958 uma modalidade de progressão continuada, criando classes de recuperação, destinadas a alunos como dificuldades, que quando recuperados poderiam voltar às suas turmas de origem, ou, caso contrário, continuar a escolarização em seu próprio ritmo.

Os índices de repetências continuaram altos durante toda a década de 60 e as taxas de evasão também cresciam. Para tentar reverter esses altos números, os Estados de Pernambuco, São Paulo e Santa Catarina optaram por flexibilizar o currículo de suas escolas primárias. Seguindo o movimento curricular em evidência nos EUA nos anos 60, Pernambuco adotou em 1968 a organização do ensino por níveis ao invés de ser por séries ou anos de escolaridade: dos seis níveis propostos, a criança deveria alcançar no mínimo quatro e o professor deveria realizar trabalho diversificado em pequenos grupos a partir de temas centrais de sua livre escolha (BARRETO e MITRULIS, 2001, p. 108).

Em 1969, é a vez de São Paulo optar por uma nova organização do currículo da escola primária. Agruparam-se a primeira e a segunda série no Nível I e as terceira e quarta séries no Nível II, com o exame de promoção somente na passagem do primeiro para o segundo nível e ao final deste (BARRETO e MITRULIS, 2001, p. 108). Os alunos que não alcançassem a promoção de um nível para outro seriam reunidos em classes de aceleração. Essa proposta de reorganização da escola primária não logrou êxito na década seguinte.

Continuando a entender como as experiências de se buscar alternativas para a reprovação no Brasil aconteceram, vejamos o caso de Minas Gerais. A Secretaria Estadual de Educação de Minas Gerais realizou uma experiência em Juiz de Fora na qual havia a tentativa de implantação de um sistema de avanços progressivos. Em 1973, ao final dessa experiência que se iniciou em 1970, as escolas apresentaram menores índices de repetência e evasão (BARRETO e MITRULIS, 2001, p. 109).

Ás experiências de reorganização do currículo dos estados de Rio Grande do Sul (1958), Pernambuco (1968), São Paulo (1969) e Minas Gerais (1970) veio somar a experiência de Santa Catarina em 1970. Segundo Barreto e Mitrulis (2001, p.109), Santa Catarina foi o estado brasileiro onde a experiência de progressão continuada se deu de modo mais expressivo, abrangente e duradouro. Além disso, o Plano Estadual de 
Educação de 1969 instituiu oito anos de escolaridade contínua e obrigatória na rede estadual deste estado o que antecipou a Lei da Reforma do Ensino de Primeiro e Segundo Graus de 1971. Este Plano Estadual de Educação, implantado em 1970, extinguiu o exame de admissão, estabeleceu os avanços progressivos, aboliu a reprovação ao longo das quatro primeiras e das quatro últimas séries. Classes de recuperação foram montadas para aqueles alunos que ao final da quarta série e da oitava série não tivessem alcançado êxito no processo de aprendizagem. Os avanços progressivos perduraram até meados da década de 80 .

Essas foram as primeiras experiências com regimes não-seriados no Brasil. Apenas Santa Catarina logrou êxito para além de uma década, as outras experiências resistiram por menos tempo. A década de 80, fruto da transição democrática pela qual passou o Brasil, trouxe os ciclos de alfabetização como alternativa para o problema da reprovação nas séries iniciais da escola obrigatória. Alguns estados das regiões Sul e Sudeste elaboraram medidas de reestruturação dos sistemas escolares tendo em vista a sua redemocratização. Nessa direção,

Os estados de São Paulo, Minas Gerais e Paraná, a começar pelo primeiro, instituíram o ciclo básico, que reestruturava, num continuum, as antigas $1^{a}$. e $2^{a}$. Séries do $1^{o}$. Grau. Tratava-se de medida inicial no sentido da reorganização da escola pública, com o objetivo de diminuir a distância entre o desempenho dos alunos das diferentes camadas da população, assegurando a todos o direito à escolaridade (BARRETO e MITRULIS, 2001, p. 112).

Dentre as experiências com o ciclos de alfabetização podemos citar o Bloco Único na Rede Estadual de Ensino do Rio de Janeiro entre 1979 e 1984. O Bloco Único consistia no agrupamento das $1^{\mathrm{a}}$. e $2^{\mathrm{a}}$. séries onde não havia reprovação dentro do Bloco. Na Rede Estadual de São Paulo foi implantado em 1983/84 o Ciclo Básico de Alfabetização (CBA). O CBA era subdividido em Ciclo Básico Inicial (CBI) o que correspondia à primeira série e o Ciclo Básico Complementar (CBC) o que correspondia à segunda série. Não havia reprovação do $\mathrm{CBI}$ para o $\mathrm{CBC}$, somente do $\mathrm{CBC}$ para a terceira série. O CBA também foi implantado em 1988 na rede estadual do Paraná.

Podemos compreender até aqui que diversas formas de se buscar resolver o problema da reprovação e da evasão escolar foram implantadas em várias regiões do Brasil. Umas duraram um pouco mais que outras. O que ficou de mais importante é que existe alternativa para a reprovação e que essa alternativa demanda esforços do governo, dos professores e da sociedade para alcançar êxito. No começo da década de 90, 
prefeituras lideradas pelo Partido dos Trabalhadores (PT) decidiram implantar o regime de ciclos nas redes municipais de São Paulo e Belo Horizonte. Falemos primeiro da experiência mineira.

A Escola Plural surge em Belo Horizonte em 1994. Esta proposta de reorganização do currículo antecipa a escolaridade e permite que crianças de seis anos ingressem no Ensino Fundamental. Foram estabelecidos três ciclos, de três anos que englobavam todo o Ensino Fundamental (temos aqui uma antecipação do Ensino Fundamental de 9 anos proposto pelo atual Governo Federal). Esses ciclos foram chamados de Ciclos de Formação e agrupavam alunos da mesma faixa etária. Os ciclos da Escola Plural tinham como eixo a vivência sócio-cultural de cada idade $e$ compreendiam o período característico da infância, da puberdade e da adolescência. [...] O aluno deveria prosseguir nos estudos com o mesmo grupo de idade, sem rupturas provocadas pelas repetências (BARRETO e MITRULIS, 2001, p. 117).

Um dos nós centrais da proposta da Escola Plural continuava a ser a repetência. Ela não podia acontecer no interior dos ciclos, mas podia acontecer de um ciclo para outro. O aluno poderia ficar mais um ano no ciclo, se não alcançasse o desenvolvimento adequado, mas não deveria distanciar-se dos seus pares de idade. $\mathrm{O}$ que fazer então com aqueles que não obtinham êxito em seu desenvolvimento? Ficar indefinidamente em um ciclo até alcançar os requisitos mínimos para seguir adiante na escolaridade? Esses dilemas levantaram a questão de que a repetência era apenas postergada e não solucionada.

Antes de nos determos na experiência com o regime de ciclos do município de São Paulo, cabe lembrar que outros municípios também experimentaram a reorganização do ensino no início da década de 90. A prefeitura de Belém do Pará adotou em 1992/1993 a organização do ensino em ciclos nos primeiros quatro anos do ensino fundamental. A prefeitura de Porto Alegre, em 1995, institui a Escola Cidadã, organizada em ciclos de formação. Foram estabelecidos três ciclos com duração de três anos cada um: Ciclo I - 6,7 e 8 anos; Ciclo II - 9,10 e 11 anos e Ciclo III - 12, 13 e 14 anos (XAVIER, 2004).

De posse do que foi discutido até agora, vejamos como a Legislação da Educação Brasileira trouxe respaldo para que o regime de ciclos pudesse ser adotado nos sistemas de ensino brasileiros. A Lei Sampaio Doria de 1920 não trouxe uma proposta de ciclos, mas apresentou um projeto de não reprovação da primeira para a segunda série da Escola Primária. Porém, as propostas de Reforma previstas nesta Lei 
não lograram êxito. A questão dos altos índices de reprovação continuou a preocupar os estudiosos da educação e voltou a ser discutida na década de 50, tendo como seu principal expoente Almeida Júnior. Apesar dos esforços em se pensar alternativas para as elevadas taxas de repetência, não foram tomadas medidas efetivas nas redes públicas de ensino, salvo o desenvolvimento de uma experiência isolada de progressão continuada no Rio Grande do Sul em 1958.

Foi somente na década de 60 que a possibilidade de organização não seriada do ensino foi estabelecida pela Lei de Diretrizes e Bases. A Lei n 4.024 de 1961 abriu a possibilidade de organização da escola de maneira alternativa ao padrão estabelecido. Em seu artigo 104 prevê, em caráter experimental, a 'organização de cursos ou escolas experimentais, com currículos, métodos e períodos escolares próprios'. Em decorrência dessa abertura legal, experiências como a de Pernambuco em 1968 (organização por níveis e não por séries), de São Paulo em 1969 (organização por níveis e não por séries), de Minas Gerais, em Juiz de Fora, em 1970 (avanços progressivos) e de Santa Catarina em 1970 (progressão continuada) tornaram-se possíveis.

A Lei de Diretrizes e Bases no. 5692 de 1971 substituiu a Lei nº. 4024 de 1961 e colocou a possibilidade de outras formas de organização do ensino como alternativa para os números do fracasso escolar. Em seu artigo 14, parágrafo $4^{\circ}$, esta Lei diz que: 'verificadas as necessárias condições, os sistemas de ensino poderão admitir a adoção de critérios que permitam avanços progressivos dos alunos pela conjugação dos elementos de idade e aproveitamento'. Mais uma vez há a tentativa de se solucionar os problemas de reprovação e evasão. A partir daí temos outras experiências de formas alternativas de organização do sistema público de ensino em algumas cidades e em alguns estados, por exemplo: o Bloco Único no Rio de Janeiro entre 1979-1983, o CBA (Ciclo Básico de Alfabetização) em São Paulo entre 1983/84 até 1995/96 e o CBA no Paraná a partir de 1988. A década de 90 também traz experiências de formas alternativas de organização da escola pública, são os casos das prefeituras de São Paulo em 1992, de Belém do Pará em 1997, de Belo Horizonte em 1994 e de Porto Alegre em 1995. Belém do Pará, Belo Horizonte e Porto Alegre instituem os ciclos de formação no lugar das séries, São Paulo institui os ciclos de aprendizagem. As propostas são muito parecidas e visam ao desenvolvimento do aluno de forma mais global e menos fragmentada. A tabela a seguir apresenta sucintamente as experiências brasileiras de ensino não-seriadas. 
TABELA 7 - Regimes de Ensino Não - Seriados

\begin{tabular}{|c|l|l|}
\hline Ano & \multicolumn{1}{|c|}{ Denominação } & \multicolumn{1}{c|}{ Estado/Município } \\
\hline 1958 & Progressão Continuada & Rio Grande do Sul \\
\hline 1968 & Organização do Ensino por Níveis & Pernambuco \\
\hline 1969 & Organização do Ensino por Níveis & São Paulo \\
\hline 1970 & Sistema de Avanços Progressivos & Juiz de Fora/MG \\
\hline 1970 & Progressão Continuada & Santa Catarina \\
\hline 1979 & Bloco Único & Rio de Janeiro \\
\hline $1983 / 84$ & Ciclo Básico de Alfabetização & São Paulo \\
\hline 1988 & Ciclo Básico de Alfabetização & Paraná \\
\hline 1992 & Regime de Ciclos & São Paulo/SP \\
\hline 1994 & Escola Plural & Belo Horizonte/MG \\
\hline 1995 & Escola Cidadã & Porto Alegre/RS \\
\hline 1997 & Escola Cabana & Belém do Para/PA \\
\hline
\end{tabular}

A LDB $n^{\circ} .9394$ de 1996, que substituiu a Lei $n^{\circ} .5692 / 71$, trouxe a possibilidade de organização do ensino em outros moldes de forma mais clara por meio da indicação de diferentes alternativas. O artigo 23 expressa que: 'A educação básica poderá organizar-se em séries anuais, períodos semestrais, ciclos, ...'. Nesse contexto, os ciclos escolares surgem com a intenção de regularizar o fluxo escolar, eliminando ou limitando a repetência e a evasão dos alunos. A discussão dessa política, e, também, da progressão continuada, da promoção automática e das políticas de não-reprovação, tornou-se acirrada. Apesar de não serem idéias novas, elas não faziam parte diretamente do dia-a-dia da maioria das escolas públicas do Brasil. Apenas algumas redes já haviam experimentado outras formas de organização do sistema público de ensino. E mesmo essas redes que já haviam experimentado o ciclo como forma de organização, como é o caso da Rede Municipal de Ensino de São Paulo, continuava a não entender exatamente como a escola deveria funcionar dentro dessa outra perspectiva. Vejamos então como os ciclos aparecem no contexto dessa rede municipal.

A experiência do ensino em ciclos da cidade de São Paulo se insere nesse contexto que vimos mostrando e está diretamente relacionado com a política do Partido dos Trabalhadores para a educação. Em 1989, Luiza Erundina assume a prefeitura de São Paulo e convida o educador Paulo Freire para ocupar a pasta da Secretaria 
Municipal de Educação (SME). Paulo Freire ficou à frente da SME de 1989 a 1992, quando se afastou do cargo. Em 1992, o professor Mario Sergio Cortella assume a pasta da SME, dando continuidade ao trabalho proposto por Paulo Freire e seus acessores. Durante o período em que Paulo Freire foi secretário, o projeto educacional visava a Construção da Escola Pública Popular ${ }^{12}$. O projeto de governo estava apoiado no eixo da nova qualidade de educação numa perspectiva popular e democrática. Os anseios dessa gestão visavam à mudança de estruturas excludentes dentro da própria escola. Neste contexto ideológico, a idéia de ciclo de aprendizagem esteve sempre presente. Mas foi somente no final da administração, em 1992, que ocorreu a implementação do regime de ciclos em toda a rede municipal. Esse regime de ciclos abarcou todo o ensino fundamental, que foi organizado em três ciclos: inicial (antigas $1^{\mathrm{a}}$., $2^{\mathrm{a}}$. e $3^{\mathrm{a}}$. séries), intermediário (antigas $4^{\mathrm{a}}$., $5^{\mathrm{a}}$. e $6^{\mathrm{a}}$. séries) e final (antigas $7^{\mathrm{a}}$. e $8^{\mathrm{a}}$. séries).

Em 1997, na gestão do prefeito Celso Pitta, uma Indicação do Conselho Municipal de Educação dizia que seguindo a tradição pedagógica brasileira, os ciclos passariam a ser apenas dois: o Ciclo I, englobando os quatro primeiros anos do Ensino Fundamental e o Ciclo II, englobando os quatro anos finais. Temos aqui uma iniciativa que foi imposta à Rede Municipal sem possibilidades reais de discussão ou reflexão por parte dos professores e de outros profissionais de educação. Essa imposição se articula com as mudanças pelas quais estava passando a Rede Estadual de Ensino de São Paulo. Em 1997, o Conselho Estadual de Educação de São Paulo institui para a Rede Estadual de Ensino o Regime de Progressão Continuada no Ensino Fundamental:

A Secretaria Estadual de Educação de São Paulo implanta, em todas as suas escolas de ensino fundamental no ano de 1998, ciclos de aprendizagem, organizados em dois blocos, da $1^{a}$. a $4^{a}$. série e da $5^{a}$. a 8. Série. [...] Como em outras propostas, entende que os avanços sociais, afetivos e cognitivos não seguem um percurso linear, não representam a soma de sucessivas aquisições, nem resultam de conquistas pontuais e específicas, mas são parte de um único processo de desenvolvimento global que decorre da inter-relação de múltiplas aprendizagens. Outro aspecto destacado é a ênfase no princípio da heterogeneidade, contrapondo-se ao secular modelo de organização do ensino centrado em tarefas uniformes, dirigidas a uma clientela pretensamente homogênea em seus interesses, necessidades $e$ possibilidades. (BARRETO e MITRULIS, 2001, p. 124).

Visando a articular possíveis transferências de alunos de uma rede para outra e sem consultar os professores que já participavam do regime de ciclos da

\footnotetext{
${ }^{12}$ São Paulo (Município) Secretaria Municipal de Educação. Construindo a Educação Pública Popular, 1989.
} 
prefeitura de São Paulo, as duas redes de ensino - Municipal e Estadual - passaram a organizar em 1998 os oito anos do Ensino Fundamental em dois ciclos de quatro anos de duração cada um. A possibilidade de reprovação continuava sendo apenas no último ano de cada ciclo.

De meados da década de 90 até os primeiros anos do século XXI as experiências com os ciclos têm aumentado em todo o Brasil, sejam nos níveis estaduais ou municipais. A Rede Estadual de Ensino de São Paulo é a única - de âmbito estadual - que tem todo o Ensino Fundamental totalmente organizado em ciclos e a Rede Municipal de Ensino de São Paulo também está completamente organizada em ciclos. Isso quer dizer que uma parcela significativa dos professores e dos alunos do Brasil (concentrados no Estado de São Paulo) tem vivenciado essa proposta de organização que rompe com a seriação.

\section{3 - Os Ciclos e as professoras: quais demandas são colocadas para o}

\section{trabalho docente?}

Agora que já apresentamos brevemente o percurso da implantação do regime de ciclos na Rede Municipal de Ensino de São Paulo e que refletimos sobre a reorganização de ensino em ciclos, tendo em vista várias experiências brasileiras, ficanos algumas perguntas: o trabalho do professor permaneceu o mesmo que era realizado quando o regime era seriado? Quais as novas demandas colocadas para o trabalho docente? Houve formação continuada para promover o desenvolvimento profissional do professor frente a esta nova organização da escola?

Para compreender estas questões, buscamos subsídios no relato das três professoras por nós entrevistadas, de modo a vislumbrar como a reorganização do ensino em ciclos influenciou o trabalho dos professores na escola. Lembramos que o relato que se seguirá não diz respeito apenas à experiência municipal de ciclos de São Paulo, mas às experiências profissionais vividas pelas professoras Margareth, Estela e Isabela no contexto da escola ciclada. Mais adiante apresentaremos com detalhes o percurso formativo de cada uma das três professoras. Por ora, fiquemos apenas com as informações mais relevantes: professora com mais tempo de experiência docente Margareth, 23 anos; professora com certa experiência docente - Estela, 14 anos e professora com menos experiência - Isabela, 3 anos. Há um espaço de cerca de 10 anos entre o tempo de experiência de Isabela e de Estela e entre o tempo de Estela e 
Margareth, isso nos auxilia a captar o conjunto de anos que dura em média a profissão docente para mulher na prefeitura de São Paulo: 25 anos.

Relembrando sua experiência com o Ciclo Básico de Alfabetização na Rede Estadual de Ensino de São Paulo no início dos anos 80, Margareth, falando sobre a implantação desta forma de organização do ensino, coloca que houve

dificuldade na implantação do projeto porque houve a implantação, mas sem as condições. Então hoje, com respaldo maior que a gente tem, seria totalmente diferente. Na época [os ciclos] foram jogados. O sistema joga e você cai de pára-quedas e tem que se virar.

O sentimento da professora é de falta de preparação do contexto escolar para aderir á nova forma de organização do tempo e do espaço da escola. E ao dizer que 'caiu de pára-quedas' e 'teve que se virar', ela nos leva a crer que houve uma necessidade de formação dos professores, que deveria ser respondida pelo sistema e pela escola, o que não ocorreu. Aqui está expressa a necessidade de formação para se trabalhar de acordo com o que os ciclos propunham e essa necessidade aponta para uma constatação ainda mais importante: o modo de ser professor precisaria se adequar a essa nova organização. Essa mudança traz em seu bojo uma formação que passa a ser essencial para que esses professores dêem conta das novas demandas que são postas ao seu trabalho no momento em que os ciclos são implantados. Sobre essa questão da formação dos professores para um efetivo trabalho em ciclo, Barreto e Mitrulis (2001, p. 129) colocam que

a falta de capacitação constitui, por sua vez, uma queixa mais geral entre os professores que trabalham sob o regime de ciclos, de vez que a pretendida mudança dos referenciais de organização da escola que pautava o seu trabalho faz com que se sintam muito inseguros em relação aos modo de atuar.

Junto com a implantação vem a necessidade da implementação. Não há como implantar uma proposta sem oferecer meios profícuos para sua implementação. As autoras Barreto e Mitrulis (2001) falam em exigência de formação continuada para esse momento de implantação e de tentativa de implementação.

A professora Margareth, também trabalhava na Rede Estadual no período de 96-98 - durante a reorganização que implantou o Regime de Progressão Continuada. Ela relata o que, segundo sua experiência, aconteceu e ainda está acontecendo nas escolas: eles falam ciclo, mas [a escola] continua seriada. Então é primeira série, segunda série, etc. Margareth mostra, por meio de sua percepção, que a questão da 
Progressão Continuada ainda está muito confusa e que a comunidade escolar e os professores parecem não ter se apropriado da idéia que permeia este Regime. Ela diz que os ciclos, dentro da proposta do Regime de Progressão Continuada, foram implantados, porém existe

muita dúvida em relação a progressão continuada, muito trabalho. Eu lembro que eu fiz [quando trabalhei] na coordenação muito trabalho com os pais sobre isso, porque era muito difícil e é até hoje, porque a gente vê reportagem, a gente vê políticos dando entrevistas e que não entendem e que falam [sobre o que não entendem].

Margareth, continuando sua argumentação para tentar explicar porque os pais não compreendem a proposta da Progressão Continuada, diz que eles não entendem o que é o ciclo porque, o sistema continua seriado. E isso dificulta aos pais perceberem o contexto maior no qual a proposta da Progressão está inserida. Esses depoimentos mostram que a proposta de organização do ensino em ciclos foi implantada na Rede Estadual de Ensino sem a sua devida implementação.

A professora Isabela, com apenas três anos de experiência na Rede Municipal, aponta falhas também na implementação da organização do sistema em ciclos da prefeitura de São Paulo, ela diz que apesar da escola ser em regime de ciclo, ela ainda é seriada na prática.

Estela, corroborando a argumentação de Margareth e Isabela, diz que a escola está organizada teoricamente em ciclo, mas na prática ainda é série. $O$ planejamento é feito por série, o conteúdo é trabalhado na série.

As três professoras são vozes oriundas do dia-a-dia das escolas municipais de São Paulo, e também de escolas estaduais, já que todas elas também já exerceram (e/ou continuam exercendo em regime de acúmulo de cargos) a docência na Rede Estadual de Ensino de São Paulo. O relato que elas nos trazem sobre o que de fato aconteceu, e ainda acontece nas redes públicas na cidade de São Paulo, ajuda a compreender que houve e continua havendo falhas na implementação dessa proposta de organização do ensino.

As percepções apresentadas pelas professoras estão em sintonia com o argumento de Perrenoud (1999, p. 8), ao afirmar que

[...] nenhum desses sistemas educacionais conseguiu implantar em larga escala uma escola sem séries que promova apenas ciclos de aprendizagem. [...] $O$ que se observa por ora é principalmente uma vontade de acabar com as barreiras das séries adjacentes, de tornar as progressões mais fluidas, abolindo ou limitando a repetência, de levar 
os professores a gerir um ciclo de maneira solidária, mediante um trabalho de equipe, se possível, no interior de um projeto da escola. Enfim, os ciclos são por enquanto apenas uma intuição; não somos capazes de concebê-los e de fazê-los funcionar promovendo uma ruptura $[\ldots]$.

Vimos, com os relatos das professoras Margareth, Estela e Isabela, que o processo de implantação das propostas dos regimes de ciclos - seja o Ciclo Básico de Alfabetização e o Regime de Progressão Continuada na Rede Estadual, ou os Ciclos de Aprendizagem na Rede Municipal - não ocorreu de forma harmoniosa e não ofereceu condições reais de implementação efetiva dos ciclos. Depois de escutar a voz de quem vivenciou e vivencia experiências de transição do modo organizacional seriado das escolas para o modo ciclado, pensamos que, para além das mudanças formais de nomenclatura (de série para ciclo), não houve transformações significativas na rotina do cotidiano escolar.

Avançando um pouco mais na discussão dos ciclos e deixando de lado a constatação de que 'na prática' o regime ainda é seriado, vamos agora ao que pensam as professoras sobre essa forma de organização do ensino.

Margareth, refletindo sobre o comportamento do aluno dentro dos ciclos diz que

há falhas no próprio sistema e que aí vai depender de cada profissional. Vou ser bem realista: ali, você vai ser responsável pra passar aquilo tanto pra família, para que haja essa parceria, quanto para os alunos de uma maneira que eles entendam [que é necessário] estabelecer regras e limites $[\ldots]$.

Essa professora nos oferece elementos para que observemos outras facetas do contexto da escola ciclada. Ela começa falando em limites e responsabilidade que existiam na seriação e que parece não ser um ponto forte dos ciclos, a menos que ocorra uma orientação contumaz. Essa orientação precisa partir da escola e da própria família. Os ciclos pressupõem uma flexibilização do currículo da escola. A necessidade de responsabilidades e limites permanece, mas eles não se configuram mais apenas na questão de 'ter nota para passar de ano'.

Margareth, ao dizer que há falhas no próprio sistema e que aí vai depender de cada profissional, aponta para a responsabilidade que é colocada a cada professor e para a falta de um trabalho coletivo na escola para que todos se apropriem da proposta dos ciclos. Um dos pressupostos da organização dos ciclos é que não haja 
ruptura do trabalho pedagógico de um ano para outro e que esse trabalho tenha continuidade e seja levado em conta para o planejamento do trabalho do ano seguinte.

A professora Estela, ao refletir sobre sua experiência com os ciclos de aprendizagem da Rede Municipal de Ensino, coloca que

Não tem mais pra onde correr. O ciclo tem que ser isso mesmo porque hoje a escola atende a todos, é para todos, acolhe crianças com caminhares diferente, com ritmos diferentes, com limites diferentes. Só que estamos no comecinho da mudança. O Dimenstein - não gosto dele - mas ele disse numa reunião que nós temos uma escola com estrutura do século XIX, com professores do século XX e com alunos - mesmo os que nasceram no final do século passado - que já são do século XXI. Então a mudança vai demorar um pouco até você conseguir assimilar tudo isso e fazer a transformação, vai demorar mesmo.

Em 2006, mesmo tendo passado mais de uma década da implantação dos ciclos da Rede Municipal, a professora Estela expressa a sensação de que ainda estamos no início da mudança. Por que uma mudança estrutural ainda não vingou em mais de uma década desde sua implantação? Quantas décadas mais serão necessárias para que os professores possam ter condições efetivas para desenvolverem seu trabalho de acordo com as demandas dos ciclos de aprendizagem? Não temos respostas para essas questões, mas os elementos que reunimos em nossa pesquisa e as análises feitas por outros autores mostram que até aqui faltaram formação e condições organizacionais do trabalho para que os professores se apropriassem da proposta e pudessem colocá-la em prática. Barreto e Mitrulis (2001, p. 128), também refletem sobre o insucesso da proposta dos ciclos ao dizer que

as condições de trabalho existentes na rede estadual [e nós estendemos essas condições também para a rede municipal] são insuficientes para garantir uma aprendizagem efetiva de todos devido ao grande número de alunos por classe, que dificulta o acompanhamento e a falta de capacitação docente.

Continuando a reflexão sobre os problemas da implantação dos ciclos na Rede Municipal (e também na Estadual), a professora Isabela diz que

O problema que eu vejo na forma como foi implantado é que há muita rotatividade de professores nas escolas pra poder dar um acompanhamento. Por exemplo: 'na quinta A, trinta alunos conseguiram chegar aos objetivos, mas os outros quinze estão ainda em outra etapa'. Quando eles forem para a sexta A no ano que vem, o professor tinha que saber 'com esses trinta, eu tenho que partir daqui e com esses quinze eu tenho que partir daqui', e isso não acontece. A idéia do ciclo era essa: você ver tudo que o aluno aprendeu durante o ano e no ano seguinte, começar a partir de onde ele parou. E como é muito heterogênea a sala 
e tem esses fatores externos que atrapalham o pedagógico, o ciclo permanece só na teoria. Por exemplo, lá na escola onde eu estou, o ano que vem -se eu continuar nessa escola, porque eu sempre entro em processo de remoção para vir mais para perto de casa - se eu continuar lá, eu gostaria de pegar a segunda série que é a minha primeira esse ano. Porque eu gostaria de dar continuidade ao meu trabalho.

Isabela oferece vários elementos que nos auxiliam na compreensão de questões que estão diretamente relacionadas aos contextos da escola ciclada e da profissão de professor na escola municipal. Por exemplo, ela nos fala da rotatividade de professores que é um fato indiscutível, já que há a possibilidade do professor se remover ao final de cada ano para escolas de seu interesse (sejam eles de ordem geográfica - trabalhar mais perto de casa, ou de qualquer outra ordem). A remoção acontece por meio de classificação, que depende do total de anos de carreira no magistério, do número de cursos de formação que o professor fez e de outros fatores burocráticos. Isabela demonstra clareza frente à proposta de continuidade de trabalho dentro dos anos do ciclo ao falar que o professor precisa ver tudo que o aluno aprendeu durante o ano e, no ano seguinte, começar a partir de onde ele parou. Como solução ela vislumbra uma saída individual, que é a vontade de continuar com a mesma turma de alunos. Mas isso não depende apenas de sua vontade e sim de ditames burocráticos e institucionais.

Não podemos colocar a rotatividade como um problema exclusivo do ciclo porque essa rotatividade acontecia também no regime seriado. O que acontece agora é que os ciclos pressupõem uma continuidade no trabalho que não era pressuposta no regime seriado. Está aqui a novidade que torna a rotatividade um problema para a efetivação dos ciclos. Isabela, continuando a falar da importância do relatório individual do aluno, diz ainda que quando

o professor faz os registros individuais ao final do ano, explicando na folhinha individual do aluno, aonde ele parou e no que ele precisa melhorar, o professor do ano seguinte muitas vezes não lê esse relatório e muitas vezes acontece de os relatórios serem perdidos.

Esses relatórios são importantes porque permitem ao professor continuar o trabalho pedagógico levando em consideração o que cada aluno já sabe. Sobre isso, Isabela conta que quando ela lecionou para os quartos anos do Ensino Fundamental, em dois anos consecutivos, 2004 e 2005

Eu fiz o relatório de cada aluno, principalmente daqueles que foram para a quinta série muito fraquinho e dos multi-repetentes - pois chega 
uma hora em que você tem que mandar o aluno para frente, mesmo este não estando totalmente alfabetizado. Você faz todo o relatório, falando do comportamento, das providências que você tomou e tudo. E o que acontece? Como muda de ciclo, não sei se esses relatórios são jogados fora pelas escolas, ou ao montar as quinta séries as antigas quartas são desmembradas, os alunos vão ser misturados. Os alunos que são muito indisciplinados são colocados um em cada sala. Tem também aquela questão que nos deixa dúvida se os relatórios serão lidos pelos professores do ano seguinte. Ás vezes dá a sensação de que ninguém vai ler.

Os elementos colocados por esta professora nos ajudam a perceber que há entraves estruturais para que o ciclo funcione de uma maneira efetiva. Isabela também nos coloca a importância da ficha individual de cada aluno na qual deve constar um relatório detalhado de cada ano escolar. Ela levanta a questão de que há professores que não detalham o desenvolvimento alcançado por cada aluno e que expressam apenas as notas deles em suas fichas individuais. Quando questionada sobre os relatórios dos terceiros anos que antecederam seus quartos anos Isabela diz que

não tinha relato, só tinha as notas. Na prefeitura é $P$ de plenamente satisfatório; $S$ de satisfatório e NS de não satisfatório. Eu só tinha isso. Só que não dizia o que o aluno não aprendeu, onde que ele tinha parado. Tava lá NS em português. Mas eu não sabia se o problema dele na quarta série era não estar alfabetizado, ou se ele tinha problemas de alfabetização. Ou problemas de ortografia, que são mais simples de resolver. Ou de interpretação. Então eu não sei onde o aluno tinha parado. Eu só sei as notas. O que é necessário fazer? Principalmente com os alunos que não têm o rendimento satisfatório? É ter um relatório. Uma coisa simples falando quais são os problemas e o que ele consegue fazer; o que ele precisa melhorar; algum problema de comportamento; como a família o acompanha, se comparece à escola, se toma providências, se não toma.

Então o ciclo deveria ser assim: você ter o acompanhamento [do aluno].

Como então dar continuidade a um trabalho que não se sabe até onde chegou na sua fase anterior? Como sanar as dificuldades de aprendizado do aluno, se não há informações sobre elas? O relatório da ficha individual é um instrumento importante de registro do desenvolvimento do aluno e pode auxiliar o planejamento do trabalho do professor. Como pode o professor conseguir dar conta de ler mais de 30 fichas (quando elas existem) se não há tempo para isso na sua jornada de trabalho? E o professor do Ciclo II que é especialista e leciona para várias turmas com mais de 35 alunos cada? Como ele pode conseguir dar conta de ler as fichas de seus inúmeros alunos? Não temos como responder a estas perguntas, mas Isabela aponta uma saída: precisa haver acompanhamento para que os preceitos dos ciclos aconteçam na prática. 
Como fazer esse acompanhamento, ou melhor, como fornecer condições de trabalho para que esse acompanhamento seja feito, cabe às Secretarias de Educação e seus gestores pensarem.

Margareth, a professora com maior tempo de carreira, referindo-se á importância das fichas individuais de registro do desenvolvimento do aluno, diz que

Há falhas também nas fichas descritivas porque o professor acaba preenchendo de qualquer forma e, às vezes, sem orientação. No ano seguinte o professor dificilmente vai pegar a ficha e [buscar saber] aonde seu aluno parou, o que ele conseguiu atingir e a partir dali começar seu trabalho.

Temos aqui o relato de uma professora com 23 anos de experiência e de outra com apenas três anos de experiência sobre a importância da continuidade do trabalho de um ano para o outro. Percebemos que, apesar do percurso formativo delas serem diferentes (como veremos mais adiante), ambas se apropriaram dessa prerrogativa da continuidade do trabalho pedagógico dentro do ciclo.

De posse dessas informações sobre o cotidiano numa escola ciclada, perguntamos às três professoras quais suas sugestões para que o ciclo funcionasse na prática. Margareth nos disse que se algumas lacunas estruturais forem sanadas como, por exemplo, a questão das fichas descritivas, ela aposta que dá para colocar o ciclo em prática. Na visão dessa professora, há a necessidade de se fazer um planejamento no qual cada professor do Ciclo I, do primeiro ao quarto ano, tenha uma visão geral pra ver até onde vai chegar. Estela também afirma que falta mudar a forma de planejamento para que o ciclo saia da teoria e passe a fazer parte da prática. Já a professora Isabela coloca que essa questão da rotatividade dos professores atrapalha a escola ciclada porque, segundo ela, dificulta a continuidade do trabalho pedagógico. Então esbarramos de novo na questão do planejamento. Percebemos que as três professoras apontam saídas, via planejamento, para a falta de estrutura que as redes colocam para o trabalho docente.

Depois dessa breve incursão pelas percepções das professoras Isabela, Margareth e Estela sobre a questão dos ciclos na escola pública, retomamos as considerações de Barreto e Mitrulis (2001, p. 136), quando estas nos chamam atenção para o fato de que

as mesmas condições para a implementação bem sucedida dos ciclos são propostas, experiência após experiência, mas elas continuam não sendo asseguradas na maioria das vezes, ou pelo menos não o são de um modo 
satisfatório para aqueles diretamente envolvidos com a mudança. [...] Tudo indica, pois que os ciclos demandarão muito tempo ainda para serem consolidados, já que o tempo de mudar no papel é muito diferente do tempo de transformar corações e mentes, e daquele requerido para moldar a nova face da escola.

As falas das professoras Isabela, Margareth e Estela nos mostram que os ciclos ainda não foram consolidados na prática e que ainda há um bom caminho a ser percorrido até que esta forma de organização do ensino logre êxito.

Depois de percorrer o relato da experiência com a escola ciclada vivenciada por cada uma das professoras entrevistadas, temos noção de que novas demandas foram colocadas ao trabalho do professor como, por exemplo, a necessidade do registro do desempenho do aluno ao final de cada ano letivo para que o professor do ano seguinte possa continuar o trabalho iniciado pelo professor do ano anterior. Frente a isso e de acordo com a forma como o ciclo foi implantado na Rede Municipal de Ensino aferimos que ainda há muitas peças desse quebra-cabeça a serem encaixadas para que possamos ver o ciclo funcionando como manda sua teoria. 


\section{CAPÍTUlO 3 - A profissão docente e o}

\section{desenvolvimento profissional}


O tema do desenvolvimento profissional de professores carrega em si a necessidade de reflexão sobre a profissão docente. A construção dessa reflexão terá como base os estudos do português António Nóvoa (1986, 1991, 1995a, 1995b, 1998, 1999 e 2000) e das brasileiras Tanuri (1969 e 1979), Dias (2002), Marcílio (2005) e Castro (2005). As autoras brasileiras trabalham diretamente com a questão da Escola Normal no Brasil no Império e no começo da República. Nóvoa trabalha a questão da gênese e do desenvolvimento da profissão docente em Portugal - em especial - e de forma geral. Seu trabalho nos ajuda a problematizar a questão docente na atualidade tendo em vista todo o seu processo de desenvolvimento.

Ao levarmos em consideração que nosso país foi colônia portuguesa de exploração por vários séculos, podemos verificar que a profissão docente no Brasil sofreu influência direta do desenvolvimento desta profissão em Portugal. Por isso os estudos de Nóvoa são oportunos para a nossa reflexão sobre a docência.

Este autor, ao tratar da história da escola em Portugal, diz que esta, a partir do século XVI, apresenta duas grandes fases: a primeira sob tutela da Igreja que dura até meados do século XVIII e a segunda sob tutela do Estado que dura até os nossos dias. Nóvoa traz a história da escola como pano de fundo para uma discussão sobre a profissão docente tendo em vista o processo de profissionalização da atividade docente (NÓVOA, 1986, p. 11). Para ele, o grupo docente que mais cedo profissionalizou sua atividade foi o dos professores primários. Essa assertiva vem ao encontro do nosso interesse em compreender o desenvolvimento profissional de professoras das séries iniciais do Ensino Fundamental no Brasil, já que as professoras das séries iniciais correspondem aos professores primários descritos por Nóvoa.

Até a metade do século XVIII o que chamamos hoje de professor dos anos iniciais do Ensino Fundamental era chamado de mestre-escola. A caracterização sociológica dos mestres-escolas não é muito fácil, devido à grande heterogeneidade dos indivíduos que exercem atividades docentes (NÓVOA, 1986, p. 15). Segundo Nóvoa há um pouco de tudo no meio das pessoas que exercem a atividade docente: artesãos, particulares, trabalhadores impedidos de exercer atividades desgastantes do ponto de vista físico, homens ligados à vida religiosa, etc. $\mathrm{O}$ autor em questão diz ainda que

o mestre-escola dos séculos XVI e XVII, indivíduo sem nenhuma preparação para o exercício da atividade docente e com um estatuto sócio-económico muito baixo, irá ser um antepassado indesejável para sucessivas gerações de professores do ensino primário que, a cada 
instante, procurarão exorcizar este fantasma, ligado à gênese da sua profissão (NÓVOA, 1986, p. 17).

Tendo em vista a questão do mestre-escola apresentada por Nóvoa (1986), fica-nos a idéia de que a profissão docente, lá na sua origem, já trazia elementos que a colocavam num estatuto menos nobre. Esse estatuto menos nobre pode ser visualizado na fala que se segue:

Não havia formação mínima exigida para o mestre-escola e este estava subordinado diretamente à ação da Igreja ou de seus representantes. A função docente não pode de início se desenvolver senão de forma subsidiária e não especializada; religiosos ou leigos, os indivíduos que se consagravam ao ensino não o faziam senão como ocupação secundária ou acessória (NÓVOA, 1991, p. 119).

Continuando o entendimento dessa questão, Nóvoa (1991, p. 114-115)

aponta que

No campo, elas [as escolas] são habitualmente conduzidas por um mestre leigo, dependente do pároco. Não há procedimentos uniformes com respeito à escola e ao pagamento do mestre: os notáveis locais, os homens de igreja e as assembléias de habitantes ou os conselhos de aldeia aí intervém com uma capacidade de decisão que muda de acordo com a região e mesmo com o lugar. Em contraste, ninguém pode ser nomeado mestre sem a aprovação das autoridades eclesiásticas. Nesta época, o contrato assinado pelo mestre (de duração muito variável) compreende quase sempre obrigações religiosas (ajudar o pároco, cantar a missa, fazer soar os sinos, etc.), comunitárias (exercer as funções de secretário da administração municipal, dar corda ao relógio, etc.) e docentes: é quase desnecessário dizer que essas últimas não são as mais importantes. De resto, uma grande parte desses mestres exerce ainda atividades agrícolas ou artesanais.

Na cidade, a situação é muito mais diversificada, pois há uma multitude de instituições que se consagram à educação da infância: escolas conduzidas por mestres leigos; sociedades de caridade e de beneficência; mestres que ensinam na casa de pessoas bem colocadas; congregações religiosas que ensinam ao mesmo tempo a doutrina cristã, a leitura; etc.

O mestre-escola, além de ser um indivíduo leigo, não tinha autonomia para desenvolver seu trabalho e não tinha uma diretriz por onde pudesse se orientar. A Igreja e as pessoas notáveis das diversas localidades escolhiam a pessoa que ocuparia a função de mestre-escola. Não havia critérios específicos para a ocupação dessa função, mas as diferentes características entre a educação no campo e na cidade são visíveis. Enquanto no campo cada localidade escolhia seu mestre-escola de acordo com as 
influências locais e com o que a comunidade pretendia, na cidade havia uma oferta maior de pessoas destinadas a cuidar da educação das crianças.

Dissemos anteriormente que coube à Igreja gerenciar o ensino até meados do século XVIII. Isso não quer dizer que o Estado esteve ausente durante este período dos assuntos da escola, ele apenas exerceu um papel secundário. As Reformas instituídas pelo Marquês de Pombal no ano de 1759 vão modificar significativamente a organização do ensino em Portugal e nas suas colônias. Sobre isso, Nóvoa (1986, p. 19) coloca que

Á diversidade educativa vai suceder-se um vasto projeto de uniformização das situações educativas e de homogeneização das práticas escolares. A partir da época pombalina é ao Estado que compete o controlo e a coordenação das atividades escolares.

Com a assunção dos assuntos do ensino e da escola por parte do Estado, o mestre-escola vai perdendo espaço nesses assuntos e surgem os mestres régios de ler, escrever e contar. Notemos que há uma forte mudança na nomenclatura do sujeito que se ocupa da função de ensinar e/ou educar as crianças. Ele deixa de ser um mestreescola e passa a ser um mestre régio. Essa mudança indica em sua nomenclatura quem é que dá as cartas no ensino a partir dessa reforma. Não há como ter dúvidas sobre o fato de que o Estado assumiu as rédeas da educação. O mestre que antigamente poderia ser qualquer sujeito de qualquer localidade passa agora a ser um funcionário do Estado que recebe seu pagamento a partir de divisas do tesouro público.

As reformas educacionais de Pombal visavam a três objetivos principais: trazer a educação para o controle do Estado, secularizar a educação e padronizar o currículo. O Marquês de Pombal pretendeu organizar o ensino por meio de uma 'rede escolar' nacional e através da nomeação de mestres régios pagos pelo Tesouro público. Para alcançar seus objetivos, ele criou um imposto especial conhecido como subsídio literário que viabilizaria o pagamento dos mestres régios. O valor desse pagamento era muito baixo, mal dava para o mestre régio se manter e manter sua família. Nóvoa (1986, p. 19-20) nos conta que essa remuneração colocava o mestre régio na mesma situação de um pedreiro ou carpinteiro das camadas mais baixas da administração pública .

A Reforma de 1759 inaugura um outro preceito legal além da criação do subsídio literário: a obrigação de uma licença exclusiva para poder exercer a função de mestre régio. Essa licença só poderia ser concedida após a realização de um exame público no qual o candidato mostrasse ter habilitação para ocupar tal função. Em seus 
estudos Nóvoa (1986, p. 21) não deixa claro que tipo de habilitação era exigido no exame público, apenas coloca que essa licença era um suporte legal para o exercício da atividade docente. Vemos aqui o início do processo de profissionalização da atividade docente. Através da criação do subsídio literário e dos exames públicos para nomeação dos mestres régios vemos nascer a profissão docente tal qual ela se configura até os nossos dias. Esta configuração diz respeito diretamente aos professores das redes públicas do Brasil porque estes, em sua maioria, são nomeados mediante aprovação em concurso público de provas e títulos e recebem seus salários através dos cofres públicos, o que evidencia que os dois definidores de grande peso na organização da profissão docente já estavam postos em meados do século XVIII.

O Estado ao assumir o controle da educação em Portugal e ao propor exames públicos para a nomeação dos mestres régios de ler, escrever e contar dá início ao processo de profissionalização da atividade docente. Não é mais qualquer pessoa com qualquer formação que pode exercer a atividade docente. As Reformas Pombalinas marcam o surgimento da preocupação com a formação das pessoas que se ocupam da atividade de ensinar a ler, escrever e contar visto que já existiam professores de gramática, retórica, filosofia, aritmética, etc. Quando falamos em processo de profissionalização da atividade docente estamos nos referindo a atividade docente que não é específica e que começou a ser exercida pelos mestres-escola e, mais adiante, pelos mestres régios de ler, escrever e contar. Dizemos isso porque apesar de já haver a classe dos professores de gramática latina, de retórica, de grego, entre outras disciplinas, é somente a partir do século XIX que os mestres começam a afirmar-se como fazendo parte integrante do grupo social 'professores', ainda que das 'primeira letras' (NÓVOA, 1986, p. 25). É sobre os professores 'das primeiras letras' - em nossos dias 'dos anos iniciais do Ensino Fundamental' - que se centra nosso interesse.

No Brasil, a história da profissão docente, apesar de sofrer influências diretas do que acontecia em Portugal, tem uma trajetória peculiar. Os primeiros professores foram os padres jesuítas porque o único ensino formal existente no Brasil até meados do século XVIII era o oferecido pelos padres da Companhia de Jesus. Os jesuítas ensinavam a uma ínfima camada de jovens brancos, proprietários, de famílias da elite colonial, além de introduzir nas primeiras letras e no catecismo elementar as crianças índias das aldeias jesuítas (MARCÍLIO, 2005, p. 3). Perscrutando a organização da Companhia de Jesus chegamos ao entendimento de que os Jesuítas priorizaram o ensino secundário porque não havia preocupação com a educação 
elementar da população. A preocupação em ensinar as primeiras letras às crianças índias tinha o interesse maior de levá-las a professar a fé católica. Diante disso podemos verificar que não havia aqui na América Portuguesa a mesma insipiência da atividade docente que havia em Portugal. Aqui não havia os mestres-escola e a educação formal estava completamente nas mãos dos Jesuítas. Marcílio (2005, p. 16) nos conta que durante o período em que os jesuítas aqui estiveram, o governo português não interveio nos seus planos de ensino e menos ainda se preocupou com eles. Apesar de o Brasil ter passado pela experiência de ensino professada pelos padres jesuítas, podemos afirmar que o processo de desenvolvimento da profissão docente no Brasil seguiu os moldes do desenvolvimento dessa profissão em Portugal: da tutela da Igreja para a tutela do Estado.

A primeira lei sobre ensino no Brasil data de 1827. Ela foi chamada de Lei Geral do Ensino e estabeleceu as diretrizes que deveriam nortear a criação de escolas no país (MARCÍLIO, 2005, p. 47). Essa lei propunha que onde houvesse vilas e lugares populosos haveria escolas de primeiras letras. Além disso, essa lei criou os cursos jurídicos no Brasil instalando uma escola de Direito em Olinda e outra em São Paulo. Na realidade a Lei Geral do Ensino ajudou a fomentar o nascimento da escola pública no Brasil, fato que em Portugal se deu por volta da segunda metade do século XVIII.

Quanto ao preparo do professor para atuar de acordo com as prerrogativas desta Lei Geral de Ensino, vimos nascer a primeira Escola Normal em 1835 na cidade de Niterói (TANURI, 1969 e 1979; DIAS, 2002; MARCÍLIO, 2005). A partir da criação dessa lei, aos poucos o ensino público e o ensino privado foram se edificando no Brasil. É nessa questão de preparo do professor, ou melhor, do desenvolvimento da profissão docente no Brasil que iremos direcionar nosso estudo.

Depois dessa breve incursão ao surgimento da profissão docente no Brasil, herdeira direta dessa profissão em Portugal, ficou claro que a preocupação com a formação dos professores da escola elementar só passou a ser pauta de discussão do Estado no final do século XIX, ou seja, temos apenas um século de história da formação docente no Brasil. Sendo que essa formação não passou de uma mera intenção de uniformização dos sujeitos que lecionavam para controle do que estava sendo ensinado às crianças e aos jovens da nação no final do século XIX. Marcílio (2005) coloca que os anos de 1870 a 1990 constituem o 'século da escola' porque esse período corresponde ao nascimento e estabelecimento dessa instituição e da própria profissão docente. Nesse 
contexto, nosso estudo se configura como uma tentativa de compreensão da profissão docente ao final do primeiro centenário dessa profissão no Brasil. Como é ser professor numa escola pública depois de um século de experiência docente no Brasil?

De acordo com o que foi visto até aqui, vislumbramos que a profissão docente no Brasil vem passando por grandes transformações desde o século XIX. Este século é responsável pelo aparecimento e estabelecimento da instituição escolar e pelo surgimento das primeiras escolas normais incumbidas da formação de professores para atuarem nas poucas escolas primárias do país. Além disso, como bem coloca Castro (2005, p. 150),

desde o período imperial já existia o propósito de formar o professor para o magistério 'primário', sendo que o governo imperial responsabilizava-se pela manutenção dos cursos superiores então existentes e reduzidos e atribuía às províncias a responsabilidade pelo ensino primário e secundário.

A preocupação com a escola elementar surge com a Independência. Há um projeto de nação a ser construído e essa construção leva à necessidade de organização do ensino público e privado no Brasil, o que começa a acontecer com a publicação da Lei Geral do Ensino em 1827. Podemos afirmar que até o final da experiência colonial o Brasil contou essencialmente com professores jesuítas. A partir do século XIX é que surgem alguns parcos mestres-escolas na província de São Paulo (MARCÍLIO, 2005) e mais tarde, com o advento das escolas normais, surgem os professores primários. Mas quem formava os professores primários? Castro (2005, p. 150) nos diz que no Brasil não existiam professores habilitados para atuar nas escolas normais na época de seu surgimento. Dessa assertiva podemos compreender que a questão da formação de professores é uma pedra no sapato da educação pública brasileira desde os primórdios da organização dessa profissão em nosso país. Sobre essa questão da formação, os republicanos paulistas iniciaram em 1890 a reforma do ensino pela reforma da Escola Normal. Um dos idealizadores dessa reforma foi Caetano de Campos. Ele não poupou esforços para a fundação de uma escola-modelo, ainda no ano de 1890, que contava com duas professoras formadas nos Estados Unidos (Souza, 1998). Essa escola-modelo ficou responsável por formar os professores primários. Em 1893 foram criados os grupos escolares em São Paulo. Temos aqui o surgimento da escola pública paulista laica. 
O início da profissionalização do magistério primário em São Paulo esteve diretamente ligado às transformações educacionais verificadas no final do século XIX. Sendo assim, a profissão docente no Brasil, tal como ela está instituída hoje, se consolidou no bojo dessas transformações. Junto a essa consolidação acontece a criação de uma imagem social do professor. Souza (1998, p. 61) tece considerações sobre essa imagem ao dizer que

a importância dada à educação popular nesse período propiciou a constituição de representações sobre a profissão docente nas quais o professor passou a ser responsabilizado pela formação do povo, o elemento reformador da sociedade, o portador de uma nobre missão cívica e patriótica. Era pelo professor que se poderia reformar a escola e levá-la a realizar as grandes finalidades da educação pública.

As várias transformações pelas quais passou o país no correr do século XIX como, por exemplo, a Independência política, a abolição da escravidão e a Proclamação da República, mostraram a importância de se organizar o ensino a serviço da construção de um ideal de nação que estivesse pautado na idéia de ordem e progresso. Essa ordem e esse progresso viriam por meio da educação pública. Daí a valorização da imagem do professor frente a esse ideal. $O$ magistério deixava de ser uma desventura e tornava-se uma profissão digna, reconhecida e edificante (SOUZA, 1998, p. 62).

Podemos observar que a crescente preocupação em se exigir formação para o exercício do magistério é um índice que atesta o início da profissionalização docente. Ser professor passou a ser uma profissão com características específicas que requer uma determinada formação, e essa formação passa a distinguir a docência de outras profissões. Souza (1998, p. 70) nos fala que a formação passou a ser o critério fundamental para o ingresso na carreira.

Percorremos, até aqui, um breve caminho que apresentou a gestação e o nascimento da profissão docente no Brasil. Ficou claro que foi apenas no final do século XIX que começaram a surgir as primeiras preocupações por parte do governo em estabelecer exigências mínimas para as pessoas que queriam se ocupar da atividade de ensinar as primeiras letras. Quisemos mostrar a origem da profissão docente tendo em vista as especificidades dos hoje chamados professores do Ciclo I do Ensino Fundamental, antigo professor primário, porque é com este professor que iremos dialogar para tentar compreender como acontece o seu desenvolvimento profissional. $\mathrm{O}$ percurso do desenvolvimento profissional nos auxiliará no entendimento dos modos de 
ser professor na escola pública contemporânea. Sobre essa questão do desenvolvimento profissional, em especial da formação, Marcílio (2005, p. 332), refletindo sobre início da profissionalização da docência e sobre os rumos que essa profissionalização tomou, coloca que

a formação do professor para o ensino fundamental e médio foi sempre precária em todo o período. Na cidade de São Paulo, a exceção esteve por conta do Instituto de Educação Caetano de Campos entre 1930 e o seu desmoronamento, após a Reforma de 1971, que rebaixou a preparação do professor primário ao nível de habilitação de $2^{\circ}$. Grau, curso sem identificação com o treinamento do professor.[...] desde as reformas de ensino dos militares (1968 e 1971) nunca mais se conseguiu treinar convenientemente o professor de educação infantil e das séries iniciais do ensino fundamental. O professor alfabetizador teve de ser improvisado, preparado diretamente na prática do magistério, sem receber, nem nos HEMs, nem nos Cefams, nem mesmo na universidade, em seus cursos de pedagogia, treinamento e formação suficiente para essa missão especial e difícil. E o trabalho do professor é central se se pretender a melhoria da qualidade de ensino.

O que o excerto acima nos coloca é que apesar de ter havido intenções positivas durante toda a história da república no Brasil e em São Paulo para a formação dos professores dos anos inicias do Ensino Fundamental, essa formação não aconteceu a contento porque foi menosprezada nas reformas de 1968 e 1971. Entendemos que o ideal formativo existente nas Escolas Normais da virada do século não foi levado adiante pelas reformas que criaram o curso de Habilitação Específica para o Magistério - HEM (que incluía o primário e a educação infantil) no início da década de 70. A HEM, ao contrário do que era a Escola Normal, passou a ser apenas mais uma habilitação no $2^{\circ}$. Grau, sem características próprias. Podemos abrir um parêntese nessa questão sobre o que surgiu após o desmantelamento das Escolas Normais: os CEFAMs (Centros Específicos de Formação e Aperfeiçoamento do Magistério) no final da década de 80 em São Paulo. Os CEFAMs promoviam educação específica e de qualidade voltada completamente para a formação do futuro professor da educação infantil e dos anos iniciais do Ensino Fundamental. Para além da questão de oferecer sólida formação para os futuros professores, os alunos ainda recebiam uma bolsa de estudos que auxiliava nas suas despesas já que eles passavam o dia inteiro na escola. A experiência dos CEFAMs no estado de São Paulo não durou nem duas décadas: ele foi criado em 1988 e foi sepultado em 2005. O governo do estado de São Paulo acabou com os CEFAMs alegando que como a LDB 9394/96 passou a exigir a formação em nível 
superior para a docência dos anos iniciais, não havia mais razão que justificasse a existência dos CEFAMs.

A promulgação da LDB 9394/96 apresentou um certo avanço no que diz respeito à formação dos professores para lecionar nos anos iniciais do Ensino Fundamental.

Quando da sua promulgação, havia o prazo de que até o final de 2006 todos os professores dos anos iniciais deveriam ter passado pelo curso superior. Como vários governos estaduais e municipais não conseguiriam cumprir o prazo, este deixou de existir e a lei não indica uma nova data para que todos os professores que lecionam para esse nível de ensino tenham formação em nível superior. Novamente a questão da formação do professor para os anos iniciais não figura entre as principais preocupações dos governos.

Em meio a todo esse interregno de propostas oficiais de formação, os professores foram se desenvolvendo profissionalmente, seja através de formação institucional promovida pelas secretarias de ensino ou pelo interesse próprio do professor. Tendo essa questão em vista, procuraremos refletir sobre como as professoras que entrevistamos se desenvolveram ao longo dos seus anos de experiência profissional.

\section{1 - A profissão docente em foco}

Para compreendermos o desenvolvimento profissional de professores é necessário que façamos antes uma reflexão sobre o conceito de profissão.

No começo deste capítulo vimos como a 'profissão docente' nasceu em Portugal e como esse modelo foi trazido para o Brasil. Colocamos aspas para utilizarmos a expressão profissão docente porque ela não nasceu como uma profissão, nasceu como uma atividade.

A corrente sociológica que estuda a questão da profissão em si coloca que ela sofre mudanças de acordo com o contexto social no qual está inserida. Sobre isso e pensando na profissão docente, Imbernón, partindo de Popkewitz, trabalha a profissionalização da função docente de modo que compreendamos que o conceito de profissão é socialmente construído e varia conforme o contexto social e cronológico no qual ele está sendo avaliado (IMBERNÓN, 1998). Continuando nesse raciocínio, lembramo-nos do que nos disse Nóvoa $(1986,1991)$ sobre a origem da docência: era uma atividade exercida pelos mestres-escola que detinham escassos conhecimentos, que não dispunham de reconhecimento social e que estavam sob controle da Igreja até 
meados do século XVIII. Quando a tutela do ensino passou para as mãos do Estado, com as reformas Pombalinas em 1759, vimos surgir a organização dessa atividade até então exercida por indivíduos leigos. Essa organização pode ser observada a partir da exigência de exame público para admissão na função de mestres régios de ler, escrever e contar e a partir da criação de fundo de divisas que pagariam o pró-labore desses mestres régios.

O contexto social da Idade Moderna e a perda de influência da Igreja levaram o Estado a articular uma tentativa de organização do ensino em Portugal, e, conseqüentemente no Brasil. Sabemos que o Marquês de Pombal enviou professores régios para lecionar algumas cátedras de latim e retórica na Bahia, no Rio de Janeiro e em Pernambuco. A fundação do Seminário de Olinda na segunda metade do século XVIII já fazia parte das repercussões das reformas surgidas em Portugal. Por muito tempo o Seminário de Olinda foi considerado o melhor colégio de instrução secundária do Brasil.

Ao longo das leituras fomos vendo que eram tidos como professores apenas os indivíduos que se ocupavam das cátedras isoladas (latim, grego, filosofia, etc.) do ensino secundário e os indivíduos que se ocupavam do ensino das primeiras letras eram tidos como mestres régios de ler, escrever e contar. Essa diferenciação na nomenclatura atesta o grau de desenvolvimento da docência no Brasil. Voltando ao que diz Imbernón (1998), o conceito de profissão precisa ser analisado dentro do contexto social em que está inserido. Podemos então dizer que até meados do século XIX era professor no Brasil apenas aquele indivíduo responsável pelo ensino secundário. Os mestres régios, responsáveis pelo ensino das primeiras letras, não eram considerados professores. Daí entendermos que a profissão docente contempla várias facetas dentro de uma única essência, que é o ensinar. Essas facetas estão ligadas diretamente com o que se ensina e a quem. Nosso interesse neste estudo é analisar o desenvolvimento profissional dos professores que atuam nos anos iniciais do Ensino Fundamental, ou seja, os mestres régios de ler, escrever e contar do final do século XVIII e início do XIX.

No Brasil os mestres régios somente assumem o status de professores primários na segunda metade do século XIX depois da promulgação da Lei Geral de Ensino em 1827 e da criação das Escolas Normais para formação desses professores primários. Essa assunção se deve à necessidade de se formar professores primários de acordo com as propostas da nação recém independente. Não poderíamos mais importar 
professores de Portugal. Marcílio (2005) nos diz que após a criação das Escolas Normais, muitos professores que lecionam nessas escolas vão estudar na Europa (com exceção de Portugal) ou nos Estados Unidos e alguns professores estrangeiros dessas nações vêm lecionar nas Escolas Normais do Brasil.

Surge assim, em meio ao improviso, a profissão de professor primário. $\mathrm{O}$ resultado de todas as mudanças pelas quais passavam o Brasil no século XIX teve como resultado o surgimento da profissão de professor primário por leis que legitimam os professores ao seu exercício e que exigem requisitos mínimos para esse exercício.

Como vimos, o nascimento da profissão de professor primário no Brasil está diretamente relacionado com a promulgação da Lei Geral do Ensino de 1827 que organiza o ensino no Brasil.

Para compreendermos melhor o significado do conceito de profissão, recorramos a um dicionário latino-português que nos apresenta a etimologia da palavra. Segundo Firmino (198-), a palavra profissão, em seu sentido etimológico, tem sua origem no latim professio que quer dizer declaração, profissão, ocupação, emprego, exercício.

Diante disso, encontramos em Sarmento (1994, p. 37-38) consideração importante sobre o conceito de profissão. Este é adepto das abordagens sociológicas que dizem que a profissão é entendida como o desempenho de uma atividade humana, apoiada num saber e em valores próprios, possuidora de atributos específicos e como tal reconhecida pelo todo social e confirmada pelo Estado. Partindo dessas considerações podemos dizer que a atividade docente no Brasil - a partir da promulgação da Lei Geral do Ensino de 1827 - foi regulamentada pelo Estado como sendo o desempenho de uma atividade humana (a de ensinar as primeiras letras, ou as disciplinas isoladas no caso do secundário) que está apoiada num saber e em valores próprios (os candidatos à função de professor precisam passar por exames públicos que irão avaliar seus saberes e valores).

Tardif e Lessard (2005, p. 27) partem do propósito de que a docência é uma profissão de interações humanas e definem profissão da seguinte maneira:

Uma profissão, no fundo, não é outra coisa senão um grupo de trabalhadores que conseguiu controlar (mais ou menos completamente, mas nunca totalmente) seu próprio campo de trabalho e o acesso a ele através de uma formação superior, e que possui uma certa autoridade sobre a execução de suas tarefas e os conhecimentos necessários à sua realização. 
Analisando a profissão docente no Brasil, podemos perceber que de certa forma, os professores, enquanto grupos de trabalhadores, ainda não conseguiram controlar seu próprio campo de trabalho à medida que existe a necessidade de concursos públicos de provas e títulos para o ingresso no magistério público. Em outras palavras, o concurso é uma conquista dos professores mas continua sendo realizado pelo Estado. É sabido também que, pelo menos na rede pública estadual de São Paulo, há como o professor ingressar na rede como professor Admitido em Caráter Temporário, sem a necessidade de concurso. Eis aqui outra forma de acesso à carreira que depende única e exclusivamente dos professores. Os professores, apesar de quase nunca serem consultados nos momentos em que as reformas do ensino estão sendo construídas, possuem uma certa autoridade sobre a execução de suas tarefas e os conhecimentos necessários à sua realização. Em última instância, são os professores quem melhor sabem a realidade da sala de aula, dos alunos, dos avanços e dos obstáculos que existem no desenvolvimento de seu trabalho.

O trabalho dos professores é controlado pelas instâncias superiores dos sistemas de ensino, mas esse controle não é uma camisa de força que impede o professor de refletir e tomar decisões que julgue importantes para o seu trabalho. Por conta disso, tomamos como sendo uma profissão o trabalho dos professores. Não concordamos com Enguita (1991, 1995 e 2004) quando este afirma que a profissão docente se enquadra na categoria das semiprofissões. Para este autor os professores seriam

um grupo profissional com uma formação superior curta, mas que não exerce seu trabalho por conta própria, no mercado, como as profissões liberais clássicas - médicos, advogados, etc. -, mas em regime assalariado, dentro dos serviços públicos, e que tem seu trabalho submetido à supervisão por parte de autoridades não-profissionais ou parte de outros profissionais. (ENGUITA, 2004, p. 110).

Pelo que vimos desde a origem da docência em Portugal e no Brasil, a atividade docente não se enquadra na categoria das semiprofissões porque por ser a docência uma ocupação complexa e repleta de especificidades aferimos que ela não pode ser comparada à medicina e ao direito por serem de origens diferentes e por terem essências diferentes. Quer dizer então que o médico e o advogado que trabalham para o poder público são semiprofissionais? O que nos parece é que há um menor prestígio da carreira do professor em detrimento da carreira do médico e do advogado. Entendemos 
que prestígio maior ou menor não são características que sirvam para atestar se uma ocupação é ou não é uma profissão.

Outro fato que nos mostra que a docência não é uma semiprofissão aconteceu na primeira reforma do ensino em Portugal ainda no século XVIII. Como já vimos, o Marquês de Pombal levou adiante um projeto reformador que começou por volta de 1750. Entre outras coisas este projeto criou um fundo de divisas para remunerar os mestres régios de ler, escrever e contar e passou a exigir exames públicos que atestassem a capacidade dos indivíduos interessados em lecionar. Estava criada uma licença especial para o exercício da atividade docente. Sobre essa licença, Almeida (1999a, p. 23) afirma que ela representou um passo decisivo para a profissionalização docente na medida em que foi a base para o estabelecimento do rol de competências necessárias ao recrutamento dos professores em suas reivindicações pela melhoria do estatuto profissional.

Pérez Gomez (2001, p. 184), continuando essa discussão sobre a docência ser uma semiprofissão e apesar das críticas à concepção da docência como profissão, considera que há pelo menos

dois elementos que podem configurar sua identidade profissional: um corpo de conhecimentos teóricos sobre o objeto de estudo e intervenção, em permanente evolução, considerado como conjunto provisório e parcial de hipóteses de trabalho e uma relativa autonomia de trabalho.

Isso nos indica que o professor, a todo momento, reflete sobre sua ação e planeja objetivos a partir dessa reflexão. O trabalho intelectual aqui é intenso e criativo. Como considerar a docência uma semiprofissão diante destas discussões? A docência, para nós, é uma profissão.

O trabalho de aprender a ensinar não está pronto e acabado porque ele sofre influências da demanda de alunos que o professor se defronta todos os anos. Como estabelecer um único rumo possível para um trabalho que depende muito da avaliação do professor e da tomada de decisões a partir dessa avaliação? Precisamos levar em conta o 'elemento surpresa' que está presente no trabalho do professor e que se configura a partir da realidade da escola na qual este profissional está inserido. A forma como o professor lida com esse 'elemento surpresa' está diretamente ligada ao seu desenvolvimento profissional. 
Dando continuidade à reflexão sobre as especificidades do trabalho docente, encontramos em Imbernón (1998) algumas idéias que indicam caminhos de compreensão para essas especificidades. Para este autor a função docente

comporta un conocimiento pedagógico específico, un compromiso ético y moral y la necesidad de corresponsabilización con otros agentes sociales; esto es así puesto que ejerce influencia sobre otros seres humanos y, por lo tanto, no puede ni debe ser una función meramente técnica de 'expertos infalibles'. Además, cuenta también con un componente práctico, ya que los profesores y profesoras adquieren un cuerpo de conocimientos y habilidades especializadas durante un período de formación a lo largo de la vida profesional como resultado de una intervención en un contexto y una toma de decisiones aplicadas a situaciones únicas y particulares que encuentran durante el desempeño de su labor. La función docente está entonces en un equilibrio entre las tareas profesionales en la aplicación de un conocimiento, el contexto en que se aplican, el compromiso ético de su función social y la estructura de participación social existente en ese momento y en la que se está comprometida (IMBERNÓN, 1998, p. 23).

De acordo com o proposto por Imbernón, a profissão de professor agrega uma série de especificidades que são, senão exclusivas, pelo menos fundamentais, para o entendimento da docência. Segundo ele, a docência não pode ser vista como uma ocupação de técnicos infalíveis por comportar conhecimento pedagógico específico, compromisso ético e moral e co-responsabilização com outros agentes sociais. Diante disso, o professor que pensar ser o detentor de todo o saber sobre a sua função e achar que pode exercê-la sem se preocupar com a interferência de outros agentes sociais não logrará êxito em sua ação pedagógica. Um dos caminhos para a boa atuação profissional parece ser o que leva em consideração o trabalho coletivo mediante diálogo com outros profissionais e com a comunidade na qual a escola esteja inserida. Por tudo isso é que devemos considerar que a tomada de decisões aplicadas a situações únicas e particulares surge como um componente essencial para compreendermos a profissão de professor na atualidade.

Essa tomada de decisões advém de um repertório de conhecimento teórico e prático sobre a ação pedagógica e está respaldado no repertório cultural que cada professor apresenta e no tipo de demanda a que este profissional deve dar resposta. Estes repertórios e o 'elemento surpresa' do contexto escolar nos ajudam a vislumbrar como o professor constrói seus modos de ser no decorrer da sua carreira. Essa constatação reforça a percepção de que a profissão docente apresenta diversas variáveis: conhecimento pedagógico específico, compromisso ético e moral, co-responsabilização 
com outros agentes sociais, componente prático, etc. E todas essas variáveis iluminam nosso caminho investigativo no qual nos predispomos a estudar a profissão docente.

O professor é um profissional do ensino. A docência é uma profissão. Sobre isso e tendo a realidade espanhola como pano de fundo, Imbernón (1998) afirma que ser profissional implica no domínio de uma série de capacidades e habilidades especiais que faz o indivíduo ser competente em um determinado trabalho e que o liga a um grupo profissional mais ou menos coordenado e que está sujeito a algum tipo de controle. O professor está sujeito ao controle do sistema que elabora a prova do concurso para o ingresso na carreira do magistério público; está sujeito ao controle das normas e orientações que são apresentadas a ele pelas instâncias superiores da educação; está sujeito ao controle através de uma avaliação anual de desempenho. Por todas essas formas de controle, o professor tem seu conhecimento avaliado o tempo todo. Então dizer que a docência não é uma profissão é incorrer ao erro.

As discussões sobre o status da docência como profissão não se encerram e continuam gerando boas reflexões entre os estudiosos do assunto. Pelas leituras que fizemos de alguns autores desse campo para trabalho de mestrado, tomamos a docência como profissão e o professor como profissional do ensino.

O que há de específico na docência no Brasil que nos faz considerá-la como profissão é poder visualizar e datar o início do seu processo de profissionalização que ocorreu ainda no século XIX no momento da promulgação da Lei Geral do Ensino em 1827. Marcelo Garcia (1994, p. 134-135), partindo do que diz Tenorth, coloca que a profissionalização de uma ocupação está diretamente ligada ao conjunto de processos historicamente analisáveis mediante os quais um grupo de profissionais logra demonstrar sua competência em uma atividade de relevância social e é capaz de transmitir a outros tal competência e de impor seu modelo frente a outros profissionais e profissões com a ajuda do Estado. Podemos verificar o que diz Marcelo Garcia ao analisarmos o caso da criação das Escolas Normais:

As escolas normais constituem o lugar certo para disciplinar os professores, transformando-os em agentes do projeto social e político da modernidade: os discursos aqui produzidos e difundidos - bem como as práticas que lhes dão corpo - edificam um novo modelo de professor, no qual as 'antigas' referências religiosas se cruzam com o 'novo' papel de servidores do Estado e da sua razão (NÓVOA, 1998, p. 23).

O Estado, ao criar as Escolas Normais, engendra um mecanismo de controle ideológico sobre a formação dos professores e ajuda, de certa forma, a 
profissionalizar a docência. Apesar de Nóvoa se referir às Escolas Normais em Portugal, encontramos semelhanças com o caso brasileiro. A criação das Escolas Normais no Brasil, na década de 30 do século XIX, inicia o processo de profissionalização da atividade docente ao passo que o curso dessas escolas passa a figurar como pré-requisito para o exercício dessa mesma atividade.

Outra forma de atestarmos o status profissional da docência é através da questão da profissionalidade docente.

A profissionalidade docente engloba o conjunto de características específicas da docência. Sobre esse assunto, Gimeno Sacristán (1995) diz que os professores desenvolvem determinados comportamentos, destrezas, valores, atitudes, e constroem conhecimentos que constituem o que é específico da profissão. A profissionalidade é o que é específico da profissão, ela qualifica a profissão. O docente ao selecionar o seu modo de ser professor engendra a sua profissionalidade e ajuda a difundir as características desta em relação ao contexto da profissão docente. Nessa direção, Papi (2005, p. 32) considera que assim como os demais profissionais, $o$ professor afirma suas especificidades e projeta, no âmbito da ação profissional, a sua profissionalidade.

Outro autor que trabalha a questão da profissionalidade é Libâneo. De acordo com seus estudos a profissionalidade é definida como conjunto de requisitos profissionais que tornam alguém um professor, uma professora (LIBÂNEO, 2001, p. 63). Esses requisitos estão relacionados ao que é necessário para o exercício profissional da docência, ou seja, os conhecimentos, atitudes e valores.

Ao falar da profissionalidade docente, Contreras (2002, p. 74) se refere às qualidades da prática profissional dos professores em função do que requer o trabalho educativa. Esse autor diz ainda que o conteúdo, significado e realização destas qualidades não vêm definitivamente fixados. Não há um acordo definitivo sobre elas, mas sim que são interpretadas de forma diferente segundo os contextos e as posições de partida (CONTRERAS, 2002, p. 74-75).

Parece-nos então que os professores (re)constroem sua profissionalidade a cada experiência de ação. Isso é o que nos aponta também Gimeno Sacristán. Para ele, o conceito de profissionalidade docente está em permanente elaboração, devendo ser analisado em função do momento histórico concreto e da realidade social que o conhecimento escolar pretende legitimar; em suma, tem de ser contextualizado (GIMENO SACRISTÁN, 1995, p. 65). A profissionalidade dos professores primários 
formados pelas Escolas Normais do século XIX é distinta da profissionalidade dos professores dos anos iniciais do Ensino Fundamental do século XXI.

A profissionalidade configura-se então como um movimento dentro do exercício profissional que está constantemente sendo solicitado porque cada experiência de ação requer a mobilização de conhecimentos, atitudes e valores específicos que advém do desenvolvimento profissional dos professores. Desenvolver-se profissionalmente exige reflexão sobre a prática e formação continuada. Nesse sentido, concordamos com Almeida (1999a, p. 10) quando esta coloca que o professor constrói sua profissionalidade mediante um processo contínuo de formação e de reflexão sobre a própria prática. Outro autor que vê relações diretas entre a profissionalidade docente e o desenvolvimento profissional é Sarmento (1994). Para ele a profissionalidade corresponde ao processo de desenvolvimento profissional. Não há desenvolvimento profissional sem a construção da profissionalidade e não há profissionalidade sem o desenvolvimento profissional.

Pelo que vimos até aqui, reafirmamos nosso interesse em estudar o desenvolvimento profissional de professores tendo em mente que estes constroem a profissão a partir de suas escolhas e da influência do contexto no qual trabalham. Partindo daí, pretendemos visualizar o que há de comum e o que há de diferente na profissionalidade docente das três professoras por nós entrevistadas a fim de compreendermos os modos de ser professor na escola pública contemporânea.

\section{2 - O desenvolvimento profissional em questão}

Entendemos por desenvolvimento o processo pelo qual se ascende de um determinado patamar a outro que está em nível mais elevado. Esse patamar está essencialmente dentro de um contexto. Por exemplo, o desenvolvimento profissional é um processo pelo qual o profissional está num patamar dentro de sua profissão, que por sua vez está inserida num contexto social, e alcança outro patamar da sua profissão que pode ou não estar inserida no mesmo contexto social anterior.

Dentre os muitos autores que têm dedicado suas atenções à questão do desenvolvimento profissional docente, Carlos Marcelo Garcia (1994) nos fala que durante algum tempo os termos aperfeiçoamento, formação em serviço, formação continuada, reciclagem e desenvolvimento profissional foram usados como sendo intercambiáveis, ou seja, um parecia ser sinônimo do outro. Mas, este autor avistou diferenças entre os termos anteriormente citados e preferiu adotar o conceito de 
desenvolvimento profissional de professores porque ele entende que este conceito se adapta à concepção do professor como profissional do ensino. Nessa direção, a professora Isabela, ao refletir sobre os cursos que são oferecidos para os professores, fala também sobre a questão dos termos reciclagem, capacitação, etc. Ela se mostra contrária à idéia de reciclagem ou capacitação de professores e diz que

não é pra reciclar, pra capacitar porque essas palavras são até meio infames. Capacitar o professor? Ele não é capaz de fazer as coisas? Reciclar? O professor não é lixo para ser reciclado. É o que a gente chama de formação em serviço, cursos que vão fazer o professor pensar de outra forma, refletir de outra forma.

Continuando sua argumentação, Marcelo Garcia (1994, p. 314-315) diz

ainda que

o conceito 'desenvolvimento' tem uma conotação de evolução $e$ continuidade que nos parece superar a tradicional justaposição entre formação inicial e aperfeiçoamento dos professores [...] o desenvolvimento profissional se especifica como uma atitude permanente de indagação, colocação de questões e busca de suas soluções.

Isabela, ao se deparar com o processo de alfabetização incompleto de alguns alunos de sua quarta série, colocou para si algumas questões e foi tentar buscar soluções.

No começo do ano, em 2004, eu não sabia o que fazer. Eu pensava que o Ba-Be-Bi-Bo-Bu não seria suficiente para esses alunos porque se eles já estavam na quarta série é porque o Ba-Be-Bi-Bo-Bu não tinha servido. Se eles viram o $\mathrm{Ba}-\mathrm{Be}-\mathrm{Bi}-\mathrm{Bo}-\mathrm{Bu}$ desde a primeira, viram na segunda e na terceira e não se alfabetizaram é porque não serviu. Eu tinha que partir para outro caminho.

O relato acima evidencia a importância do professor refletir sobre seu trabalho, sua formação e sua relação com a profissão. Não podemos nos desenvolver profissionalmente sem exercer uma profissão. É no exercício da profissão que o indivíduo constrói sua profissionalidade docente e se desenvolve profissionalmente.

Outra autora que trabalha a questão do desenvolvimento profissional de professores é Almeida (1999a, 1999b, 2004 e 2004b). Para ela, é a partir da combinação da base de conhecimentos teóricos com a prática que o professor vai adequando sua formação às exigências de sua atividade profissional, num processo contínuo de desenvolvimento profissional (ALMEIDA, 2004a, p. 173). Essa adequação está presente no depoimento da professora Isabela quando esta nos diz que foi fazer o curso do PROFA (Programa de Formação de Professores Alfabetizadores) para poder 
compreender melhor o processo de alfabetização dos alunos. Mesmo trabalhando com uma quarta série, esta professora tinha três alunos que ainda não estavam alfabetizados. Vejamos agora seu depoimento sobre sua formação contínua frente às exigências profissionais:

O PROFA é um curso que ajuda a entender como acontece a aquisição da escrita e da leitura pela criança. Esse curso mudou muito a minha visão sobre alfabetização, sobre como preparar as atividades desafiadoras pra cada nível de hipótese de escrita. Porque você não pode falar assim "ah,o aluno não sabe nada". Ele sabe muito, mesmo que o aluno que você pede para escrever, por exemplo, 'gato' e ele coloca quinze letras e fala que ali ta escrito 'gato', ele já sabe que precisa usar letras para escrever. Tem aluno, que no começo da alfabetização, você pede para escrever gato, ele desenha um gato, acha que ali está escrito gato, então a gente chama de garatuja, ele usa desenhos ou outros símbolos sem ser letra. Então eu passei, com esse curso a ver que todos os alunos sabem alguma coisa e que o nosso desafio é propor atividades para que eles dêem um passo além do que eles já sabem. Esse curso foi muito importante para mim porque me ajudou a alfabetizar os três alunos que em plena quarta série ainda não estavam alfabetizados.

O relato de Isabela, além de mostrar claramente a importância de cursos de formação contínua que ajude o professor a refletir sobre sua prática, nos revela traços de seu desenvolvimento profissional a partir do momento em que ela coloca a mudança que houve no seu modo de conceber a alfabetização. Essa mudança só ocorreu porque Isabela refletiu sobre sua prática como alfabetizadora e decidiu buscar outros caminhos que a ajudassem a alfabetizar os aluno. Percebemos aqui o caráter reflexivo de sua ação. Sobre isso, concordamos com Almeida (1999a, p. 16) quando esta nos fala da importância de considerarmos o professor como profissional reflexivo na medida em que seu pensamento é que orienta sua ação:

Considerando então que o professor pensa e age em função de suas idéias sobre o conhecimento, o ensino e a sociedade, das necessidades específicas de seus alunos e do contexto de sua escola, parece-nos que tomá-lo como um profissional reflexivo é a concepção mais acertada para tratar dos múltiplos aspectos de sua formação e atuação, uma vez que é seu pensamento que orienta sua ação. Sua atividade profissional é fruto do conhecimento gerado no contato com a prática, ou seja, depende do conhecimento que ele elabora durante sua própria intervenção.

O conhecimento gerado a partir do contato com a prática é permeado pelas concepções de mundo do professor. Essas concepções são elaboradas a partir da vivência social, cultural, econômica, psicológica, emocional, intelectual, acadêmica, institucional e subjetiva de cada professor. Durante sua intervenção o professor mobiliza 
todo o seu repertório 'existencial' que traz em si todas essas vivências colocadas no início deste parágrafo. Então não podemos dizer que o que influencia no desenvolvimento profissional do professor seja apenas o contexto institucional ou o contexto formativo no qual este profissional está inserido. Todas as vivências apontadas anteriormente ajudam a constituir o ser humano professor. Por isso, mais uma vez afirmamos que partimos do princípio que o desenvolvimento profissional é um movimento que acontece no exercício da profissão. Esse exercício está permeado pelas experiências de humanidade do professor que orientam sua ação na sala de aula. E sua ação é regida pelo seu pensamento, pelas suas idéias. Nóvoa sintetiza bem essa nossa discussão ao dizer que a maneira como cada um de nós ensina está diretamente dependente daquilo que somos como pessoa quando exercemos o ensino. (...) É impossível separar o eu profissional do eu pessoal (NÓVOA, 2000, p. 17).

Continuando a discussão sobre a questão do desenvolvimento profissional, Almeida (2004a, p. 173-174) diz ainda que

dar conta de gerir o processo de ensino-aprendizagem na perspectiva da qualidade social exige um profissional que:

- domine a área específica de conhecimento na qual ele aprofundou seus estudos e domine os saberes didático-pedagógicos, necessários na mediação de sua relação com os alunos e o conhecimento;

- assuma de maneira responsável os compromissos éticos e as responsabilidades da profissão;

- participe da gestão coletiva da escola e partilhe os aspectos coletivos do trabalho docente;

- coordene sua formação contínua na perspectiva do seu desenvolvimento profissional, reconfigurando sua identidade profissional individual $e$ coletiva;

- estabeleça boas relações com os colegas e outros profissionais da área, com alunos, pais e a comunidade.

Vemos, a partir dessa relação de qualidades apresentada por Almeida, que a assunção do conceito de desenvolvimento profissional é o mais adequado para a construção de uma análise sobre os modos de ser professor porque este conceito nos permite perscrutar todas as facetas da docência, desde a formação inicial do professor até as razões que estão presentes nas suas escolhas ao longo da carreira. O professor não parece ser um fantoche que se deixa manipular pelo que propõe as instâncias que administram os sistemas de ensino, mas sim um ser dotado de esquemas de reflexão que lhe oportunizam tomar decisões pautadas em ações ou em estudos.

Em outro trabalho Almeida (1999a, p. 16) coloca que o desenvolvimento profissional dos professores depende de dois aspectos centrais: a formação e as 
condições em que eles exercem sua ação educativa. Podemos visualizar isso no depoimento da professora Estela quando esta nos diz que foi fazer o curso de matemática justamente por trabalhar com crianças que tinham ódio ou medo de matemática.A faculdade foi bastante interessante e tudo, mas não me ajudou a solucionar isso. Eu só fui aprender mesmo lendo Wallon. Este autor ajudou Estela, como ela própria diz, a tentar compreender melhor o que se passa na cabeça da criança, suas emoções, seus medos.

Dando sequiência ao que foi exposto até agora, nos parece ser incoerente separar o lado pessoal do lado profissional do professor no momento de fazer a análise do seu percurso de desenvolvimento profissional. Sobre isso Nóvoa (1995, p. 16) apresenta três aspectos da vida do professor que se apresentam como indissociáveis: a vida do professor que configura o desenvolvimento pessoal, a profissão docente que configura o desenvolvimento profissional e a produção da escola que configura o desenvolvimento organizacional. A vida do professor está diretamente ligada a esses três aspectos. Isso nos ajuda a ratificar a importância do nosso trabalho de mestrado que estuda o desenvolvimento profissional de professores para compreender os modos de ser professor na escola pública contemporânea.

Almeida (1999a, p. 45), ao continuar a análise da questão do desenvolvimento profissional de professores, coloca que

a idéia de desenvolvimento profissional permite redimensionar a prática profissional do professor, colocando-a como resultante da combinação entre o ensino realizado pelo professor e sua formação contínua, permeada pelas condições concretas que determinam a ambos. Também pressupõe a articulação dos professores com as condições necessárias ao seu desempenho e à sua formação e a quebra do isolamento profissional que impede a transmissão de conhecimentos entre os professores.

O redimensionamento da prática profissional do professor permite captar as influências tanto de formação quanto de experiência que resultam no processo de desenvolvimento profissional. Esse desenvolvimento traz ao professor a oportunidade de refletir sobre sua prática e de modificá-la ou não de acordo com suas vivências.

Outra autora que traz contribuições para a temática do desenvolvimento profissional é Souza (2005). Para ela

O desenvolvimento profissional engloba um conjunto de fatos, ações, opiniões, crenças e conhecimentos que se associam com a profissão. Compreende aspectos diversos como a história pessoal de cada um, a formação acadêmica recebida, a trajetória pessoal seguida, a 
experiência, os quais configuram uma forma de ser professor, uma maneira de entender a profissão e a profissionalidade. Pressupõe que o professor redefina o seu papel, discutindo na escola, nos sindicatos, nos horários coletivos e com todos da comunidade escolar (SOUZA, 2005, p. 58).

O que Souza nos diz no excerto acima vem corroborar o que já vínhamos discutindo sobre o desenvolvimento profissional docente: os fatores pessoais se somam aos fatores de formação e de reais condições de trabalho do professor e a reunião desses fatores ajuda a dar corpo ao processo de desenvolvimento profissional. O sentido do desenvolvimento profissional dos professores está estruturalmente ligado às suas vidas pessoais e profissionais e aos contextos escolares nos quais estão inseridos e realizam sua atividade docente.

Vimos até aqui que os autores por nós estudados (ALMEIDA, 1999 e 2004; MARCELO GARCIA, 1994; NÓVOA, 1995 e 2000 e SOUZA, 2005) convergem numa mesma direção em relação á temática do desenvolvimento profissional de professores: a história pessoal de cada um, com todas suas experiências e vivências, contribui diretamente para o desenvolvimento profissional juntamente com a formação inicial e continuada e com as condições reais de trabalho no contexto da escola. Debruçarmos, agora, nossas atenções para os estudos sobre desenvolvimento profissional do britânico Christopher Day (1999).

Há mais de vinte anos Day contribui para a investigação e reflexão do desenvolvimento profissional de professores. Ele atribui interesse especial para as linhas de investigação que utilizam as histórias de vida dos professores e seus trabalhos diários na sala de aula como fonte para o entendimento das questões relacionadas ao desenvolvimento profissional. Michael Eraut, no prefácio do livro de Day (1999, p. 10), relata que

Mesmo que existissem menos mudanças, o desafio de se adaptarem às necessidades individuais dos alunos e de procurarem melhorar a qualidade do próprio ensino e das atividades profissionais a ele inerentes exigiria o desenvolvimento profissional de professores.

Sobre isso a professora Margareth fala que o professor

vai amadurecendo procurando melhorar e aprendendo. Porque a cada ano, a cada turma, ou com cada dificuldade de cada aluno, o professor ta aprendendo, ta buscando novos rumos, novas direções. E você vai somando. Então, mesmo depois de 23 anos em sala de aula, eu estou sempre aprendendo. Então não adianta falar 'eu tenho 23 anos, eu sei tudo', não, de repente você fala 'poxa, eu não sabia isso'. 
Sabemos que os sistemas de ensino, principalmente os públicos, passam por mudanças que pretendem trazer melhoria para o processo ensino-aprendizagem. Uma dessas mudanças, no caso do Brasil, foi a promulgação da LDB 9394/96 que trouxe a obrigatoriedade de formação em nível superior para os professores da educação infantil e do ensino fundamental e a importância da formação continuada para todos os profissionais do ensino. Para além dessas mudanças, temos a questão das demandas colocadas pelos alunos a cada experiência escolar e, muitas vezes, a cada experiência de cada sala de aula de uma mesma escola. Então o professor precisa lidar com as mudanças dos sistemas de ensino e com as demandas do contexto de trabalho. Mesmo que não haja mudanças, ou que elas demorem a acontecer, as demandas do contexto de trabalho do professor colocam para ele a necessidade de reflexão, análise e avaliação da qualidade do seu trabalho constantemente. Isso, por si só, justifica a importância do desenvolvimento profissional docente que não pode ficar estagnado e que se pretende flexível e dinâmico. Day (1999, p. 15) também defende que o sentido do desenvolvimento profissional dos professores depende das suas vidas pessoais e profissionais e das políticas e contextos escolares nos quais realizam a sua atividade docente.

Este autor britânico enuncia alguns princípios que ajudam a visualizar a importância do desenvolvimento profissional de professores. São eles: a promoção de formação adequada aos professores e garantia de bem-estar profissional; a promoção do desenvolvimento profissional contínuo como garantia de acompanhamento de mudanças e renovações do próprio conhecimento e da perspectiva sobre o bom ensino; o estímulo a aprendizagem que englobe o conhecimento da experiência e o conhecimento teórico; a assunção de que ensinar é um processo complexo; a participação dos professores no seu próprio processo de aprendizagem; o planejamento do desenvolvimento profissional é tarefa do professor, da escola e do governo (DAY, 1999, p. 16-17). Esses princípios procuram representar todas as facetas que estão envolvidas no processo de desenvolvimento profissional do professor. Os princípios podem ser vistos como propostas de ação para que se alcance êxito no percurso formativo contínuo do professor.

Ao falar da importância desse percurso formativo, Day (1999, p. 19) descreve ainda o papel profissional do professor. Para ele, o bom profissional professor precisa 
estabelecer e manter elevados padrões de ensino; interagir de forma diferenciada com uma diversidade de alunos, com necessidades, motivações, circunstâncias e capacidades distintas, mas para os quais as expectativas, em termos de resultados, devem ser apropriadas e aliciantes; ser um membro ativo nas comunidades de adultos, dentro e fora da escola; responder às exigências externas de mudança $e$ comprometer-se profissionalmente, com entusiasmo e autoconfiança, dentro da contínua agitação que caracteriza a vida na sala de aula e na escola.

Ao descrever o papel profissional do professor, Day (1999, p. 19) coloca que o propósito central do desenvolvimento profissional é possibilitar aos professores a realização desse papel dentro dos mais variados contextos em que os professores trabalham e onde tem lugar a aprendizagem. Isso nos mostra que quando tratamos de desenvolvimento profissional de professores devemos estabelecer alguns recortes para orientar nossa reflexão. Um desses recortes é assumir o papel do professor como profissional do ensino e não como membro de uma organização de caridade, por exemplo. Não devemos esperar que o professor seja o responsável por sanar todas as mazelas da sociedade e nem que deva assumir o papel de pai, mãe, psicólogo, etc. O papel do professor, como profissional do ensino, é zelar pelo bom andamento do processo de ensino-aprendizagem de todos os alunos sob sua tutela. Portanto, concordamos com Day quando coloca que o propósito central do desenvolvimento profissional é dar condições para que o professor cumpra seu papel como profissional do ensino.

Depois de tecermos considerações importantes sobre o processo de desenvolvimento profissional de professores e tal como ressalta a nossa leitura nas proposições de autores como Nóvoa (1995 e 2000), Marcelo Garcia (1994), Almeida (1999a, 1999b, 2004a e 2004b), Souza (2005) e Day (1999), decidimos acolher a definição proposta por Day para o entendimento do conceito de desenvolvimento profissional por considerarmos ser ela bem completa. Para este autor

$O$ desenvolvimento profissional envolve todas as experiências espontâneas de aprendizagem e as atividades conscientemente planificadas, realizadas para benefício, direto ou indireto, do indivíduo, do grupo ou da escola e que contribuem, através deste, para a qualidade da educação na sala de aula. É o processo através do qual os professores, enquanto agentes de mudança, revêem, renovam e ampliam, individual ou coletivamente, o seu compromisso com os propósitos morais do ensino, adquirem e desenvolvem, de forma crítica, juntamente com as crianças, jovens e colegas, os conhecimentos, as destrezas e a inteligência emocional, essenciais para uma reflexão, planificação e 
prática profissionais eficazes, em cada uma das fases das suas vidas profissionais (DAY, 1999, p. 20-21).

De acordo com o que discutimos até aqui, podemos aferir que o desenvolvimento profissional de professores está diretamente ligado à mudança de pensamento e da prática docente através de um processo de aprendizagem contínua. Sobre isso, Day (1999; p. 293) diz que

O desenvolvimento profissional assenta fundamentalmente na mudança do pensamento e da prática - e dos contextos onde ocorrem - no sentido de melhorar a qualidade das experiências de aprendizagem dos alunos $e$, conseqüentemente, proporcionar melhores oportunidades para atingirem melhores resultados.

Quando os professores se desenvolvem profissionalmente, o trabalho realizado por eles ganha em qualidade porque é fruto de um processo de reflexão, análise e avaliação sobre a prática pedagógica à luz de teorias sobre o ensino. Desenvolver-se como profissional contribui para a aceitação da docência como profissão que requer constante aprendizagem por parte do professor.

Refletindo sobre o seu desenvolvimento profissional a professora Margareth, com 23 anos de experiência, diz que a formação continuada e a troca de experiências com os colegas de profissão são essenciais porque tanto no curso de magistério quanto na universidade ela não adquiriu todo o embasamento para o seu trabalho. Então é no dia-a-dia ali no seu grupo, nas unidades, que o professor vai diferenciando e aprendendo a cada dia. O professor está sempre aprendendo. Esta professora nos diz ainda que através dos estudos na rede municipal ela passou a trabalhar com as duplas produtivas que é uma forma de agrupar os alunos pelo nível de conhecimento para que um aluno ajude o outro a avançar no seu processo de aprendizagem. Margareth teve contato com a metodologia das duplas produtivas no curso do TOF (Projeto Toda Força ao Primeiro Ano - Programa Ler e Escrever) em 2006. Ela disse que já trabalhava com as duplas já há algum tempo, mas não era realmente a dupla produtiva pra aprendizagem. Temos aqui mais um indício de que a formação continuada atrelada à realidade da sala de aula ajuda o professor a melhorar sua ação pedagógica e a desenvolver-se profissionalmente.

A professora Estela (14 anos de experiência), ao comentar sobre seu desenvolvimento profissional, diz que

quando eu entrei no estado em 92, como estagiária, eu achei que fosse pegar o livro didático, como todo mundo, se parou na página 21, vai pra 
22, entendeu? Que os alunos iam sentar e copiar. Então o que eu tinha que explicar pra eles? Olha vocês têm que por o x no quadradinho aqui e pronto. Achava que isso aí tava bom demais. Foi o que aconteceu comigo. Eu aprendi a ler e a escrever dessa forma. E é possível. É por isso que eu não acho ruim fazer silabário, fazer treino ortográfico, porque aprende. Cada um tem um jeito de aprender. Quem me garante que o meu aluno não aprende com a repetição? Então em 92, eu achava que ía ser a coisa mais simples. Mas quando eu peguei lá uma criançadinha que eu falava pra eles que 'um mais um é dois', e, 'gente, junta uma caneta com outra caneta aqui e dá dois' e eu não conseguia estimular o aluno, eu percebi que não ía ser tão simples. $O$ meu grande 'bum' foi com a matemática. Eu pensava 'mas que que é isso', 'como é que pode'. Aí você vai começar a discordar de alguma coisa, a prestar atenção, a perceber que o livro didático não dá conta. Que você ler e falar que é porque é, não resolve. Tem que procurar resposta mais convincente.

Quando eu fiquei inquieta com a matemática, eu fui fazer faculdade. Eu quero saber, quero entender como que eles aprendem matemática. E porque eles não gostam de matemática. E o curso só me mostrou que o curso de matemática não é pra fazer entender nada de matemática, é só pra fazer prova, pra tirar nota, e você aprende que as coisas aconteceram e foram ensinando e foram aprendendo, mas que não resolvia muita coisa e aí eu pensei 'vou ter que procurar um jeito entre a gente mesmo, entre nós professores'. Aí você procura um professor que sabe mais. Mas eu achava assim: se eu aprendi com o livro, se até hoje todo mundo aprendeu só fazendo as coisas do livro e decorando a tabuada, eles também vão aprender. Se não aprender esse ano, no ano que vem, uma hora eles vão aprender. E se não aprender, vão trabalhar, deixar a escola e vão trabalhar. Não tinha a menor idéia de que era possível você usar tantos instrumentos, tantos recursos pra ensinar uma coisa. E às vezes não precisava ensinar era só perguntar pras crianças que algumas crianças já sabiam matemática. Já tinham matemática inserida neles. Tinha criança que vendia verdura na rua com carriola. Quer mais matemática que isso? Então eu fui descobrir que eles sabiam muito de matemática. Só não estava dentro dos padrões que a escola queria.

O detalhado relato de Estela conta como aconteceu avanço significativo no seu desenvolvimento profissional. Ela parte da ingenuidade do início da carreira quando pensava que ser professora era dar conta do livro didático, mostra o momento em que começou a ficar inquieta frente à dificuldade dos alunos em aprender matemática e descreve a descoberta de outros caminhos para levar o aluno a querer aprender essa disciplina. Estela traz a questão da formação em nível médio e em nível superior como incompleta para a atuação na sala de aula e mostra a importância das 
trocas de experiências com os colegas no momento em que ela vai tentar entender matemática com seus pares de profissão.

A professora Isabela, com apenas três anos de experiência, também reflete sobre seu desenvolvimento profissional ao dizer que:

Em 2004, eu comecei totalmente perdida, não sabia o que ensinar na quarta serie. Não tinha nenhum livro didático. Cheguei na escola no primeiro dia e falei 'me dá um livro didático aí. Aí na segunda vez que eu peguei quarta série, em 2005, já foi diferente, já selecionei melhor o que trabalhar, até porque já tinha passado por alguns cursos de formação continuada como, por exemplo, o PROFA (alfabetização) e o Vivências Culturais. Quando eu peguei a primeira série, em 2006, eu já tinha uma noção de como eu iria alfabetizar: trabalhar com listas de palavras, com parlendas, textos de memória, cantigas de roda, que são textos que fazem parte do universo da criança. Então meu desenvolvimento profissional é esse: partiu do tradicional e do não saber o que ensinar, e com a prática e os cursos eu fui melhorando e vendo que caminho que eu queria seguir. Não está definido ainda por completo porque eu acho que isso muda sempre. Mas hoje, o que eu defino como minha prática profissional é isso: trabalhar os diferentes tipos de textos, vendo as questões de gramática dentro dos textos e na parte de matemática, tentar trabalhar com raciocínio lógicomatemático. Não só automático 'quanto é dois mais dois', 'cento e cinqüenta menos vinte', e sim tentar fazer o aluno entender o que significa o conceito. Então a minha dificuldade hoje é em como melhorar a matemática.

Em seu depoimento, Isabela faz um resumo do que aconteceu em sua carreira nesses três anos de experiência com os anos iniciais do Ensino Fundamental. Dois anos (2004 e 2005) lecionando para quarta série e um ano (2006) lecionando para primeira série. Assim como a professora Estela, Isabela também fala sobre a questão de a formação em nível médio e superior ser incompleta ao relatar que foi num curso de formação contínua oferecido pela Secretaria Municipal de Educação - o PROFA - que ela pôde construir sua concepção de alfabetização e pode melhorar sua prática de acordo com as necessidades dos alunos.

As professoras Margareth, Estela e Isabela forneceram informações importantes do dia-a-dia de salas de aula de Escolas Municipais de Ensino Fundamental de São Paulo que nos ajudaram a visualizar o que Nóvoa (1995 e 2000), Marcelo Garcia (1994), Almeida (1999a, 1999b, 2004a e 2004b), Souza (2005) e Day (1999) debatem sobre o desenvolvimento profissional de professores. No próximo capítulo vamos apresentar o percurso profissional de cada uma das professoras em detalhe. 


\section{CAPÍTulo 4 - Modos de desenvolvimento}

profissional na Escola Municipal 
...para saber, para fazer, para ser ou para conviver, todos os dias misturamos a vida com a educação. Carlos Rodrigues Brandão.

Nos capítulos anteriores apresentamos de forma sucinta as professoras que colaboraram com o nosso trabalho e justificamos as razões que nos levaram a escolher trabalhar com Magareth, Estela e Isabela como parceiras no esforço por compreender os modos de ser professor na escola pública contemporânea. No presente capítulo iremos deter nossa atenção de forma mais detalhada sobre a formação inicial dessas professoras e sobre seus percursos profissionais. Partimos da idéia de que os relatos das professoras entrevistadas nos ajudam a vislumbrar como o desenvolvimento profissional acontece, de uma forma geral, com os professores da Rede Municipal de Ensino de São Paulo.

\section{1 - Formação Inicial}

Para podermos tecer uma análise detalhada sobre como ocorre o desenvolvimento profissional de professoras do Ensino Fundamental, necessitamos saber qual a formação inicial dessas professoras e qual o percurso profissional trilhado até o momento em que foram entrevistadas. Logo abaixo apresentamos uma tabela com o percurso formativo dessas professoras.

TABELA 8 - Formação inicial e atuação profissional

\begin{tabular}{|l|l|l|l|}
\hline Nome & Margareth & Estela & Isabela \\
\hline Idade & 42 & 45 & 26 \\
\hline Magistério & $1981 / 1984$ & $1983 / 1986$ & $1996 / 1999$ \\
\hline Graduação em & $\begin{array}{l}\text { Pedagogia } \\
1986 / 1988)\end{array}$ & $\begin{array}{l}\text { Matemática } \\
(1996 / 1999)\end{array}$ & $\begin{array}{l}\text { Letras } \\
(1999 / 2003)\end{array}$ \\
\hline Início da carreira em & 1983 & 1992 & 2004 \\
\hline Atuação em 2006 & Ens. Fund. I & $\begin{array}{l}\text { Ens. Fund. I } \\
\text { Educ. Infantil }\end{array}$ & $\begin{array}{l}\text { Ens. Fund. I e II } \\
\text { Ens. Médio }\end{array}$ \\
\hline
\end{tabular}

De acordo com os dados da tabela vemos que apesar de Margareth e Estela pertencerem a uma mesma faixa etária, elas iniciaram suas carreiras em momentos diferentes: Estela começou a lecionar quase uma década depois de Margareth. Vemos também que Isabela é mais jovem que as demais professoras e iniciou sua carreira cerca de vinte anos após Margareth. Podemos notar que os inícios das carreiras das três professoras distanciam-se uns dos outros cerca de dez anos, ou 
seja, Estela começou a lecionar quase dez anos depois de Margareth e Isabela mais de dez anos depois de Estela. Esse distanciamento nos ajuda a compreender a carreira ao longo dos anos de seu desenvolvimento. Em outras palavras, como temos o relato de uma professora com mais de vinte anos de experiência docente, de outra com mais de dez anos de experiência e de uma terceira professora iniciante na carreira, podemos vislumbrar como o desenvolvimento profissional acontece com professoras com diferentes anos de experiência no magistério. Acreditamos que com esses três depoimentos é possível vislumbrar a carreira docente como um todo a partir do depoimento das três professoras. Isso nos ajuda a avançar nos estudos sobre o desenvolvimento profissional, pois os três depoimentos nos fornecem informações que contribuem para a compreensão do modo como hoje é possível encaminhar o desenvolvimento da atuação docente em escolas públicas.

As três professoras têm em comum o fato de terem feito o curso de Habilitação Específica para o Magistério, em nível médio, como formação inicial mínima para o exercício da docência.

Margareth, a professora mais experiente, cursou no começo da década de 80 o curso de Habilitação Específica para o Magistério (HEM). Este curso a habilitou a lecionar para os anos iniciais do Ensino Fundamental e para a Educação Infantil. Ela nos conta que a escolha da carreira veio desde a infância porque eu já tinha o sonho de ser professora. Minha brincadeira predileta era escolinha. Então eu sempre sonhei com esta profissão e nunca consegui pensar em outra coisa. A carreira docente era sonho da infância que esta professora realizou ainda no início da vida adulta. Logo após o curso de HEM, Margareth fez a graduação em Pedagogia.

A segunda professora com mais experiência docente, Estela, cursou o HEM também na primeira metade da década de 80 no interior de São Paulo. Ela nos revela como foi parar na profissão docente:

Eu não escolhi ser professora. Eu fiz magistério porque era o único curso que tinha na minha cidade. Eu fiz o Ensino Médio, normal, regular e depois disso como eu não tinha condições de ir para Ribeirão Preto pra fazer faculdade eu fui fazer a escola técnica de magistério. Nunca sonhei em ser professora. Nem de pequenininha. Eu trabalhava numa fábrica de brinquedos, era gerente geral. Eu tinha mesa cheia de papelada, nota fiscal e adorava essas coisas todas. Em 1990, eu já estava casada, sofri um acidente de carro e tive algumas seqüelas mais fortes. Então eu não podia fazer muito esforço físico porque os médicos não recomendavam. Só que tinha um problema: eu comecei a ficar sem fazer nada, muito ociosa. A cabeça funcionava a mil e aí eu resolvi que 
precisava trabalhar. Uma das atividades que eu podia fazer era ser professora porque a atividade física não era tão grande como as outras. A partir daí me inscrevi como estagiária no Estado, lá tinha estagiária ainda, comecei trabalhando meio período só, como estagiária.

Ao contrário de Margareth, Estela nos surpreende ao relatar que o que a levou à carreira de professora foram as seqüelas que ficaram em seu corpo devido a um acidente de carro. Neste momento não vamos falar sobre sua graduação em Matemática porque a escolha em fazer esse curso se encaixa melhor na categoria da formação contínua e não na da formação inicial. Mais adiante retomaremos essa questão.

Isabela, a professora com apenas três anos de experiência docente, cursou o Normal (antigo HEM) na segunda metade da década de noventa. Ela nos diz que escolheu a profissão de professora porque era um sonho de infância:

Eu sempre quis ser professora. Desde criança, eu brincava muito de escolinha e gostava muito de estudar, gostava muito da escola. Então assim, sempre me vi, quando crescesse, ensinando outras crianças, adolescentes. E foi um caminho em direção a isso. Depois que eu terminei de fazer a oitava série, eu fui procurar uma escola que tivesse magistério na rede estadual.

Assim como Margareth, Isabela, desde a infância, quis ser professora. Esta professora começou sua graduação em Letras concomitante ao quarto e último ano do curso Normal. A conclusão do terceiro ano do Normal dava o certificado do Ensino Médio que era necessário para a entrada na Universidade. Desta forma, em 1999, Isabela cursava o primeiro ano de Letras na USP no período da manhã e o último do curso Normal numa escola estadual no período da tarde. Era uma dupla jornada de estudos.

\section{2 - Percurso Profissional}

Como vimos anteriormente, o desenvolvimento profissional dos professores está diretamente ligado às suas vidas pessoais e profissionais e às políticas e contextos escolares nos quais realizam sua atividade docente (DAY, 1999, p. 15). A partir de agora detalharemos o percurso profissional de Margareth, Estela e Isabela a fim de entender como a vida pessoal, a vida profissional, as políticas públicas em educação e os contextos escolares influenciaram o desenvolvimento profissional dessas professoras. 


\subsection{Professora Margareth - 23 anos de docência}

Comecemos pela professora com maior tempo de carreira docente, lembrando que quando falamos em carreira docente estamos abarcando suas vertentes institucionais e pessoais. Em outras palavras e com ajuda de Tardif (2005, p. 20) a carreira pode ser compreendida como processo temporal marcado pela construção do saber profissional. Esse saber profissional sofre influência das instituições pelas quais o professor passa ao longo desse processo temporal.

\section{TABELA 9 - Percurso Profissional: Professora Margareth}

\begin{tabular}{|l|l|}
\hline Data & Atividade \\
\hline $1983-1984$ & Profa. Voluntária na Educação Infantil (Pref. de Ferraz de Vasconcelos) \\
\hline $1985-1989$ & Profa. ACT de Primeira a Quarta Série (Rede Estadual de Ensino de SP) \\
\hline $1990-1991$ & Profa. ACT no curso de Magistério (Rede Estadual de Ensino de S P) \\
\hline $1991-1994$ & Profa. Efetiva de Educação Infantil (Prefeitura de Suzano) \\
\hline $1992-1993$ & Vice Diretora em Escola Estadual \\
\hline $1994-1996$ & Dona de Escola de Educação Infantil \\
\hline $1997-1998$ & Profa. Coordenadora Pedagógica (Rede Estadual de Ensino de S P) \\
\hline $1998-2000$ & Profa. Eventual de Ensino Fundamental I (Prefeitura de S P) \\
\hline $2000-$ & Profa. Efetiva Adjunto de Ensino Fundamental I (Prefeitura de S P) \\
\hline $2000-$ & Profa. ACT de Ensino Fundamental I (Rede Estadual de Ensino de S P) \\
\hline
\end{tabular}

A tabela acima ilustra as atividades docentes realizadas pela professora Margareth ao longo dos seus vinte e três anos de experiência no magistério. Margareth conta como foi seu início como professora.

Antes do término do magistério, eu já iniciei na educação infantil. Era um convênio que existia entre a prefeitura de Ferraz e o MOBRAL na época e que existiam salas de pré-escola. Então eu comecei com salas assim. Isso foi em 1983. Foi minha primeira experiência. Aí é claro, foi difícil, eu tremi na base, é complicado. Mas, era uma vontade imensa que eu tinha e eu fiquei nesse emprego como voluntária em 1983 e 84. Quando foi em 84, eu me formei no curso de magistério e aí eu queria fazer pedagogia. E tive que parar porque eu era voluntária.

Seu relato mostra como foi a primeira experiência com uma turma de alunos sob sua responsabilidade. Esse primeiro contato com a docência se deu através da educação infantil. Logo após o término do curso de magistério Margareth procurou a Rede Estadual de Ensino de São Paulo para lecionar como professora ACT - Admitida em Caráter Temporário. O professor ACT é denominado atualmente como professor OFA - Ocupante de Função Atividade. Esse professor é quem substitui o professor titular da classe quando este precisa se ausentar da sala de aula. Margareth nos conta 
que como professora eventual ela tinha que seguir à risca o que os professores passavam. Ela diz ainda que o professor eventual tinha o que seguir e que ele não podia sair fora do que o professor da classe estava trabalhando. Se o eventual fizesse alguma coisa fora do que ele [o professor titular da classe] dava, tinha reclamação.

Como bem menciona Margareth, o professor eventual não tinha autonomia de trabalho e tinha que seguir à risca o conteúdo deixado pelo professor titular da classe. Ela fala ainda sobre a reclamação que existia quando o conteúdo era passado de forma diferente ou era substituído por outro assunto. Não havia trabalho em equipe. Cada professor era responsável pela sua sala e os professores eventuais tinham que se submeter ao estilo dos professores titulares.

Durante mais de vinte anos, de 1985 até 2006 (momento da entrevista), Margareth, mesmo tendo se afastado do Estado por um pouco mais de um ano, sempre se manteve ligada à Rede Estadual de Ensino como professora ACT. Quando exerceu as funções de Vice-Diretora e de Professora Coordenadora Pedagógica, ela foi designada para estas funções através do seu vínculo como professora ACT. Esta professora nos conta como ascendeu ao cargo de Vice-Diretora:

Recebi um convite pra ser assistente de direção numa escola que estava recém inaugurada. Assumi também esse desafio. Afastei-me das aulas do curso de magistério e fiquei com a educação infantil em Ferraz e como Vice-Diretora nessa escola que era de primeira a oitava série.

$\mathrm{Na}$ carreira do professor tanto da Rede Municipal quanto da Rede Estadual de Ensino de São Paulo há a oportunidade deste profissional ser designado para outras funções do Magistério como, por exemplo, direção, vice-direção, coordenação pedagógica, entre outras. O professor pode ascender (via indicação por designação ou via concurso público) à funções e/ou cargos mais prestigiados e melhor remunerados dentro da carreira do magistério público. Encontramos alusão sobre essa questão de designação de professores para outras funções do magistério em Bolívar (2002). Este autor trabalha com a idéia de 'carreira horizontal' e 'carreira vertical', proposta por Becker em 1952 para os professores de escolas de Chicago. Becker propõe que a carreira horizontal se limita a possibilidade de mobilidade geográfica entre os centros de ensino, já a carreira vertical se refere à possibilidade de alcançar outras funções mais prestigiadas e melhor remuneradas dentro do próprio magistério, ou do sistema de ensino. Este autor norte-americano diz que a carreira dos professores de Chicago está mais para horizontal do que para vertical. Bolívar (2002) afirma que na 
Espanha a mobilidade vertical dentro da profissão docente é quase nula. Outro autor que fala da dificuldade de ascensão vertical dentro da carreira docente é Marcelo Garcia (1994).

O percurso profissional de Margareth nos mostra que seu desenvolvimento aconteceu também de forma vertical quando esta professora assumiu as funções de vice-diretora e de professora coordenadora pedagógica. Esse percurso nos traz a impressão de que há uma diferenciação do desenvolvimento profissional do professor quando este alcança outras funções dentro da carreira do magistério. Ele passa a ter uma visão de outro patamar que enriquece o seu olhar como docente. Entendemos isso porque o professor que passa por uma vice-direção ou pelo posto de coordenador pedagógico necessariamente precisa fazer uma reflexão sobre o que ele pode desenvolver com os professores que estarão sob seu gerenciamento, ou seja, ele passa a ser formador de professores e gestor de uma instituição de ensino. Novamente queremos lembrar que apesar de termos a Rede Municipal de Ensino como referência para nosso trabalho, o desenvolvimento profissional da professora não está pautado apenas em suas experiências como docente da escola pública municipal. Margareth carrega em si e em suas ações o conjunto de experiências que vivenciou ao longo de toda a carreira. Por isso é importante levar em conta que seu percurso na profissão e seu desenvolvimento profissional sofreram influências da carreira instituída na Rede Estadual também.

Apesar de ter passado pelas experiências de Vice-Diretora e Professora Coordenadora Pedagógica, Margareth não nos forneceu informações detalhadas sobre essas funções. Ela falou mais detalhadamente sobre o período em que ela se viu lecionando para alunas do curso de Magistério.

Eu tinha que passar teoria, mas eu trazia pra sala de aula as minhas experiências como professora. Então eu acho que complementava o trabalho através dessas experiências porque afinal já eram, na época uns 10 anos. Eu tinha alguma certa experiência, uma certa prática pra passar.

Esse destaque que Margareth dá à sua atuação prática é respaldado por Freire (2001, p. 17): O diálogo se dará em torno da prática das professoras. Falarão de seus problemas, de suas dificuldades e, na reflexão realizada sobre a prática de que falam, emergirá a teoria que ilumina a prática.

Margareth mostra a preocupação em atrelar teoria à prática na formação das jovens professoras. Ela quis trazer sua experiência como professora dos anos iniciais do Ensino Fundamental para sua sala de aula do curso do Magistério. Sobre essa 
questão, Tardif (2005, p. 39) coloca que os próprios professores, no exercício de suas funções e na prática de sua profissão, desenvolvem saberes específicos, baseados em seu trabalho cotidiano e no conhecimento de seu meio. Esses saberes brotam da experiência e são por ela validados. O professor é sujeito de sua ação e carrega em si uma cultura que é singular porque subjetiva e plural(is) porque institucional(is). Tardif (2005, p. 234), ao assumir que os professores são atores, sujeitos de seu fazer profissional, admite

que a prática deles não é somente um espaço de aplicação de saberes provenientes da teoria, mas também um espaço de produção de saberes específicos oriundos dessa mesma prática. Noutras palavras, o trabalho dos professores de profissão deve ser considerado como um espaço prático específico de produção, de transformação e de mobilização de saberes e, portanto, de teorias, de conhecimentos e de saber-fazer específicos ao ofício de professor.

Para além das experiências profissionais arroladas até aqui, Margareth abriu e gerenciou uma escolinha particular de educação infantil, sobre isso, ela conta que

eu quis partir para um novo desafio que era montar a escola de educação infantil. Eu me afastei do estado em 94 eu montei a escolinha. Sem sociedade. Na época eu precisava de dinheiro de fundo de garantia, então eu me exonerei do cargo de Educação Infantil na prefeitura de Suzano. Fiquei de 1994 até metade de 96 com a escola. Foi uma experiência muito boa. Era meu sonho. Eu fiz pedagogia, terminei pedagogia em 88, e o meu sonho era realmente abrir uma escolinha. Eu fiz pedagogia pensando na administração de uma escola de educação infantil. Mas eu dei azar, não sei se eu escolhi mal o bairro pra montar a escola. Então, o prédio era muito bom, dava pra fazer tudo que eu imaginava, só que a clientela era de baixa renda, então meu prejuízo foi muito grande. Eu consegui fazer coisas que eu queria. Mas chegou o terceiro ano da escola no qual eu estava colocando dinheiro de outra fonte para mantê-la funcionando. Aí eu resolvi parar e voltei no ano seguinte, em 1997, pro Estado, mas como coordenadora.

Essa experiência revela o lado empreendedor da professora Margareth: ela montou uma escola particular de educação infantil e a administrou por dois anos e meio. Parece que a experiência dela como vice-diretora em 1992 e 1993 a animou a gerenciar sua própria instituição. Outra vez notamos o desenvolvimento vertical da carreira desta professora. Desta vez não no sistema público de ensino, mas na rede particular. Margareth abriu uma escola para fazer as 'coisas' do jeito que ela 'queria'. Mas ela não nos informou quais seriam essas coisas e o movimento próprio da 
entrevista nos impossibilitou de voltar a este assunto visto que ele não se configurava como o cerne do nosso estudo.

Logo que o empreendimento de montar sua própria escola não obtém êxito, Margareth volta a trabalhar na Rede Estadual de Ensino como professora Admitida em Caráter Temporário (ACT), mas, antes mesmo de assumir a sala de aula, ela é designada Professora Coordenadora Pedagógica (PCP). Dentre as atribuições da função o PCP realiza tarefa de formação junto aos professores da unidade escolar em Horário de Trabalho Pedagógico Coletivo (HTPC). Durante a reorganização que houve na Rede Estadual de Ensino entre os anos de 1995 e 1996, foi criado o HTPC como momento remunerado dentro da própria jornada de trabalho do professor, onde este se reúne com seus pares para juntos estudarem os assuntos concernentes à prática pedagógica e à escola de forma geral. Vemos novamente Margareth desenvolvendo-se verticalmente na carreira. Esta professora ficou nesta função por dois anos. Em 1998, ela assume pela primeira vez um cargo na Rede Municipal de Ensino de São Paulo como professora eventual (contratada) do ciclo I do Ensino Fundamental.

Em 2000, a professora Margareth assume pela primeira vez um cargo como professora efetiva na prefeitura de São Paulo. Depois de mais de quinze anos de docência, Margareth se efetiva como professora dos anos iniciais do Ensino Fundamental na categoria de professor adjunto ${ }^{13}$ da Rede Municipal de Ensino de São Paulo. Ela se mantém neste cargo até o presente momento e ainda não conseguiu se efetivar na Rede Estadual de Ensino mesmo depois de tantos anos de experiência.

Tendo em vista o percurso profissional de Margareth, tivemos uma pequena noção do traçado que seguiu seu desenvolvimento profissional. Apesar deste ser um estudo que tem a Rede Municipal como referência, a amplitude das experiências do percurso profissional precisa ser buscada individualmente e fora da estrutura de apenas uma rede de ensino.

Vamos agora ao percurso profissional da professora Estela.

\subsection{Professora Estela - 14 anos de docência}

Estela, no momento da primeira entrevista (setembro de 2006), contava com catorze anos de experiência no magistério.

\footnotetext{
${ }^{13}$ Como já explicamos anteriormente, o professor adjunto é efetivo, mas não está lotado na escola e sim na coordenadoria de educação. Os professores adjuntos escolhem suas aulas depois dos professores titulares.
} 
TABELA 10 - Percurso Profissional: Professora Estela

\begin{tabular}{|l|l|}
\hline Data & Atividade \\
\hline $1992-1995$ & Profa. Estagiária de Primeira a Quarta Série (Rede Estadual de SP) \\
\hline 1996 & Profa. ACT na Classe de Aceleração (Rede Estadual de SP) \\
\hline $1997-2001$ & ATP de Classe de Aceleração (Oficina Pedagógica - SEE/SP) \\
\hline $1999-$ & Profa. Efetiva Titular de Ensino Fundamental I (Pref. SP) \\
\hline $2001-2002$ & $\begin{array}{l}\text { Profa. Designada como Profa. Orientadora de Informática Educativa } \\
\text { (Pref. SP) }\end{array}$ \\
\hline $2002-2005$ & Profa. Designada como Profa. Orientadora de Sala de Leitura (Pref. SP) \\
\hline $2004-$ & Profa. de Desenvolvimento Infantil (Prefeitura de São Paulo) \\
\hline
\end{tabular}

De acordo com a tabela acima, podemos visualizar as atividades realizadas por Estela em seu percurso profissional na carreira do magistério. Essa professora iniciou sua atividade docente no começo da década de 90 como professora estagiária de primeira a quarta-série na rede estadual de ensino. Havia essa denominação de 'professor estagiário', que significa a mesma coisa que professor ACT, professor eventual, substituto, etc. Estela nos conta como foi esse começo:

Me inscrevi como estagiária no Estado. Comecei trabalhando meio período. Fiquei dois anos como estagiária. Eu era professora eventual, substituta. Assumia a sala quando o professor não estava presente. Mas tinha salário remunerado. Em 92 eu comecei a ser estagiária. No segundo ano de estagiária, eu já assumi sala o ano todo porque uma professora ficou de licença.

A rede estadual de ensino ainda hoje contrata professores não concursados, admitidos em caráter temporário, para ser substituto dos professores efetivos. Já na rede municipal, a grande maioria dos professores, mesmos os adjuntos que são substitutos, são concursados e efetivos. A professora Estela fala em detalhes como foi construindo sua carreira na Rede Estadual de Ensino como professora Admitida em Caráter Temporário e como, ainda no início, foi convidada para trabalhar num Programa especial da Secretaria Estadual de Educação:

Em 93 eu já assumi a sala. Uma terceira série. A professora pegou licença prêmio o ano inteiro. Depois, em 94, eu participei da atribuição e já peguei sala normalmente como ACT. E fui trabalhar no Carrãozinho, uma escola da periferia. Trabalhei em 94 e 95 sempre com primeira e segunda série. Em 96 eu assumi a sala de aceleração. Fui convidada para trabalhar na sala de aceleração, que era um projeto do Estado para defasagem idade série das crianças.

Estela conta que conseguiu ficar com uma mesma sala durante todo o ano letivo de 1993, 1994 e 1995 e que em 1996 assumiu a sala de aceleração. Sobre esse 
assunto, Marcilio (2005, p. 365) coloca que o programa das classes de aceleração configurou-se como uma das mudanças inovadoras ocorridas no ensino paulista na década de 90. Segundo esta autora, essa inovação se deu através da introdução da avaliação para correção do fluxo escolar na rede pública, através do programa Reorganização da Trajetória Escolar: Classes de Aceleração introduzido em 1996. Marcilio (2005, p. 365), citando Vera Lucia Wey, diz ainda que o pressuposto deste programa

era que crianças que haviam repetido mais de uma vez e eram mais velhas que seus colegas de turma possuíam potencial de desenvolvimento cognitivo para acompanhar uma aprendizagem acelerada. Concebeu-se para essas classes um projeto pedagógico especial, que envolvia uma nova organização física das classes, metodologia de ensino diferenciada, materiais didáticos próprios, uma concepção de avaliação voltada para realimentar o planejamento das atividades em sala de aula durante o ano todo, professores capacitados e apoio das famílias.

Estela foi convidada, por conta do seu bom desempenho como professora de primeira e segunda série, a trabalhar no Programa das Classes de Aceleração. Isso denota que esta professora tinha um trabalho diferenciado dos demais professores. No final de 1996, depois de quase um ano de experiência na sala de aula com as Classes de Aceleração, Estela conta que ela foi convidada para trabalhar na Oficina Pedagógica, onde trabalhou entre 1997 e 2001. A Oficina Pedagógica é um departamento das Diretorias de Ensino da Rede Estadual responsável pelo desenvolvimento de projetos inovadores para o ensino e responsável, também, pela formação dos professores. Quem trabalha na Oficina Pedagógica são professores efetivos ou admitidos em caráter temporário com aulas atribuídas. Esses professores deixam a sala de aula e são designados a trabalhar como ATP - Assistente Técnico Pedagógico - nas Diretorias de Ensino. O ATP passa por cursos de formação e depois se torna formador de professores. Estela foi ATP por cinco anos:

Eu era ATP de aceleração. Assistente Técnico Pedagógico de aceleração. A gente capacitava os professores que trabalhavam com primeira a quarta série e com aceleração. E ajudava em tudo que envolvia alfabetização e letramento. Foi uma época maravilhosa porque eu tive curso com a Telma Weiz. Uma semana junto com a Telma Weiz e com vários outros pedagogos. Foi lá que eu conheci Paulo Freire, Luckesi..a Terezinha Rios. Então foi uma época ótima.

O relato acima mostra que houve uma formação específica para os professores que trabalharam com as Classes de Aceleração e a professora em questão 
diz que foi uma experiência muito boa poder ter contato com todos esses grandes pensadores da educação.

Estela trabalhou de 1992 a 2001 apenas na Rede Estadual de Ensino como professora Admitida em Caráter Temporário. De 1997 a 2001, ela se afastou da sala de aula e assumiu o posto de ATP de Aceleração na Oficina Pedagógica. Dois anos antes de deixar a rede estadual, Estela começou a lecionar na prefeitura. Ela foi aprovada num concurso para professor das séries iniciais do Ensino Fundamental.

Eu comecei na prefeitura em 1999, como titular de cargo de Fundamental I e não dei conta de ficar com os dois cargos. Então, depois de acumular por dois anos, eu optei por ficar com o efetivo na prefeitura. Com a sala de aula. Com a prefeitura e desisti da Oficina Pedagógica do Estado. E estou até hoje trabalhando. Em 2004 eu comecei no CEI também a acumular cargo de novo. Esse ano eu tenho uma primeira série no fundamental I e tenho o mini grupo EF como Professora de Desenvolvimento Infantil.(professora Estela).

Nos primeiros sete anos da carreira, Estela teve apenas um cargo de professora na rede estadual. Em 1999 ela começou a acumular um cargo não efetivo no estado com um cargo efetivo na prefeitura. Levou essa vida de acúmulo por dois anos, ficou muito cansada e decidiu deixar o cargo do estado. Ficou só com a prefeitura por dois anos e meio e em agosto de 2004 ela passou a acumular dois cargos efetivos de professora da prefeitura: um de Escola Municipal de Ensino Fundamental (EMEF) e outro de Centro de Educação Infantil (CEI). No CEI, Estela é Professora de Desenvolvimento Infantil (PDI) e trabalha com a primeira infância. Ela se diz muito feliz com essa nova experiência porque nunca havia trabalhado com a educação infantil. Estela relata também que, quando deixou o estado em 2001, preferiu ficar com o cargo efetivo, mas, principalmente, com a sala de aula. Ela sentiu vontade de voltar para a sala de aula.

Estela, além da experiência nos cargos efetivos na prefeitura, também foi designada para outras funções no magistério municipal. Ela foi Professora Orientadora de Informática Educativa (POIE) e Professora Orientadora de Sala de Leitura (POSL). O POIE e o POSL têm jornada de trabalho diferente do professor da sala de aula comum e ganha a mais por isso, desenvolvendo atividades por 40 horas semanais. Durante todo o ano de 2001 e metade do ano de 2002, essa professora foi POIE. Ela organizou o laboratório de informática de sua escola e montou aulas de informática educativa para todos os alunos da escola. Toda EMEF tem um laboratório de informática e um professor responsável por esse laboratório. Na segunda metade de 2002 até dezembro de 
2005, Estela foi POSL. Como Professora Orientadora de Sala de Leitura, ela preparava aulas também para todas as turmas da escola. Toda EMEF tem uma sala de leitura onde há rico acervo de livros de literatura, didáticos, paradidáticos e de formação do professor também, além de outros materiais pedagógicos. Cada turma da escola tem uma aula por semana na sala de leitura e uma aula no laboratório de informática.

Fazendo um breve balanço, Estela lecionou por quatro anos consecutivos para os anos iniciais do Ensino Fundamental da Rede Estadual; depois lecionou um ano para a Classe de Aceleração. No ano seguinte, em 1997, foi designada para trabalhar na Oficina Pedagógica como Assistente Técnico Pedagógico de Aceleração. Ficou nessa função até 2001. Em 1999 começou a acumular o seu cargo de ATP com um cargo efetivo de Professor Titular de Ensino Fundamental I da prefeitura de São Paulo. Em 2001 ela se desliga do Estado e assume a função de Professora Orientadora de Informática Educativa na prefeitura. Fica nessa função por um ano e meio e no segundo semestre de 2002 assume o posto de Professora Orientadora de Sala de leitura, ficando nesse posto até 2005. Em 2004, Estela assume um novo desafio em sua carreira: lecionar para a primeira infância. Em 2006 volta para a sala de aula regular e continua acumulando cargo como Professora de Desenvolvimento Infantil.

De acordo com as idéias de Becker, analisadas por Bolívar (2002), sobre 'carreira horizontal' e 'carreira vertical', verificamos que Estela desenvolveu-se de modo horizontal e vertical. Quando esta professora começou a pegar sua própria turma para lecionar, em uma escola diferente a cada ano, e quando ela assumiu seu cargo efetivo de professor na prefeitura de São Paulo, experimentou diferentes situações pedagógicas que enriqueceram seu repertório didático e que a fizeram desenvolver-se horizontalmente dentro da carreira do magistério. Ao assumir e desempenhar a função de Assistente Técnico Pedagógico, na Oficina Pedagógica, por cinco anos, Estela ascende verticalmente dentro da carreira do magistério. Vimos que a possibilidade de alcançar outras funções dentro do magistério é possível para aquele professor que se destaca de algum modo. E esse destaque veio com apenas cinco anos de atuação em sala de aula regular como Professora Admitida em Caráter Temporário na Rede Estadual de Ensino de São Paulo. Além dessa experiência 'vertical', ela também é designada como Professora Orientadora de Informática Educativa e de Sala de Leitura em momentos diferentes. Essa é mais uma experiência vertical na carreira porque a professora em questão experimentou uma função 'mais prestigiada' e 'melhor remunerada' que a do professor em sala de aula regular. Podemos então dizer que Estela desenvolveu-se 
profissionalmente tanto de forma horizontal (diferentes escolas) quanto de forma vertical (diferentes funções dentro do magistério).

\subsection{Professora Isabela - três anos de docência}

A professora Isabela, mais nova e com menor tempo de experiência docente é a única dentre as três professoras entrevistadas que já iniciou sua carreira no magistério como Professora Efetiva Titular de Ensino Fundamental I na Rede Municipal de Ensino de São Paulo. Notemos que no mesmo ano em que iniciou como professora concursada na rede municipal também iniciou na rede estadual na mesma situação.

TABELA 11 - Percurso Profissional: Professora Isabela

\begin{tabular}{|l|l|}
\hline Data & Experiência Profissional \\
\hline $2004-$ & Profa. Efetiva Titular de Ensino Fundamental I (Prefeitura de SP) \\
\hline $2004-$ & Profa. Efetiva de Língua Portuguesa (Rede Estadual de Ensino de SP) \\
\hline
\end{tabular}

A tabela acima mostra o percurso profissional trilhado por Isabela desde o ano em que ingressou na carreira como professora concursada e efetiva das duas redes públicas de ensino de São Paulo até o momento das entrevistas. Isabela nos conta como foi o início desse caminho como professora:

Em fevereiro de 2004 eu iniciei na prefeitura. Eu nunca tinha trabalhado antes com esse nível de ensino e eu não tinha material nenhum em casa para preparar aula. Não tinha livro didático de quarta série, nem das outras séries e não tinha noção de que conteúdo eu ía passar. Apesar de eu ter feito magistério, eu não tive tudo na formação. Então foi muito difícil para mim, porque eu não tinha absolutamente noção de nada, então eu tive que conversar com os outros professores na escola, pegar os livros na escola mesmo, pra ver o que eu podia começar a trabalhar.

Isabela desnuda as dificuldades de seu começo. Ela nunca tinha lecionado para os anos iniciais do Ensino Fundamental porque não foi professora eventual, substituta, ACT, etc. Ao contrário de Margareth e Estela, que primeiro percorreram um caminho como professora não concursada, Isabela já iniciou a carreira num cargo efetivo e depois de ter terminado a faculdade de Letras. Seu começo profissional, distante vinte anos do começo de Margareth e cerca de dez anos do começo de Estela, a coloca numa posição muito diferente das colegas entrevistadas: ela teve que construir seu repertório pedagógico a partir de sua formação inicial, sem a experiência de ter sido professora substituta. Acreditamos que quando o professor vivencia uma experiência de substituição de outro professor, ele acaba aprendendo com 
o modo de ser desse outro professor. De repente, ele aprende a não fazer do jeito que o professor titular da sala faz, mas ele tem um espelho para onde olhar.

O professor que assume sua primeira experiência como professor titular da classe parte da sua experiência como aluno e da formação que teve para dar os primeiros passos com seus alunos. Não há saberes da experiência, há insegurança e vontade de seguir adiante.

Depois de perscrutar o percurso profissional de Margareth, Estela e Isabela, podemos analisar melhor o desenvolvimento profissional de cada uma delas. É o que veremos a seguir.

\section{3 - Desenvolvimento Profissional}

Durante todo o trabalho de mestrado, tomamos como base a pessoa do professor para entender sua carreira profissional e suas escolhas dentro dessa carreira. Dito de outro modo, nós quisemos articular os processos formativos do ponto de vista daquele que se forma, inseridos em sua trajetória pessoal e profissional. Esses processos formativos nos levaram diretamente para o contexto do desenvolvimento profissional de cada professora entrevistada.

Não há como falar em desenvolvimento profissional sem falar em formação. Formação no sentido amplo que diz respeito ao ser humano como ser incompleto, que está sempre buscando formas apropriadas para se relacionar com o mundo de acordo com seu ponto de vista próprio. É no formar-se que acontece o desenvolvimento pessoal e profissional. Paulo Freire (2001, p. 58) nos faz lembrar bem disso ao dizer que ninguém começa a ser educador numa certa terça-feira às quatro horas da tarde. Ninguém nasce educador ou marcado para ser educador. A gente se faz educador, a gente se forma, como educador, permanentemente, na prática e na reflexão sobre a prática. Ou seja, o professor, mesmo que não perceba a mudança, se apropria das experiências que vivencia e as integra ao seu repertório cultural e vai ser formando e no formar-se se desenvolve.

Acreditamos que um aspecto fundante do desenvolvimento profissional de professores é o movimento contínuo, muitas vezes não consciente, de apropriação de experiências vivenciadas individual e coletivamente no contexto da carreira do magistério. Essa apropriação acontece de acordo com os pressupostos teóricos, filosóficos, éticos, estéticos, didáticos, pedagógicos, culturais, históricos, etc. de cada professor. Nessa direção, Bolívar (2002, p. 105), citando Fullan, diz que $o$ 
desenvolvimento profissional, desse ponto de vista, veio a ser a soma total do conjunto de experiências formais e informais acumuladas ao logo de uma carreira.

O desenvolvimento profissional não pode ter sua dimensão pessoal esquecida ou deixada de lado. Bolívar (2002, p. 120) fala que muitos estudos tratam os professores como se fossem todos iguais, falando em geral de estereótipos de professores inovadores, tradicionais, resistentes à mudança, etc. Esses estereótipos não dialogam com a realidade porque cada professor, mesmo diante de iguais condições de trabalho, respondem aos dilemas do dia-a-dia escolar de formas variadas. Bolívar (2002, p. 95), citando Lacey, diz ainda que o desenvolvimento profissional se refere a um processo contínuo de ajuste situacional (ativo ou passivo) do indivíduo à cultura da profissão, com opções e escolhas ao longo do tempo, que dão margem a carreiras diferenciadas. Cada professor escolhe os caminhos do seu percurso profissional, sendo que esses caminhos sofrem influência direta das instituições pelas quais os professores passam e pelas experiências de vida que estes experimentam. Sobre isso, Bolívar (2002, p.16) coloca que os indivíduos constroem seu curso vital em função das escolhas e atos que praticam nos limites das oportunidades proporcionadas pelas circunstâncias sociais e históricas.

Nosso estudo, que busca valorizar a dimensão subjetiva da vida do professor, procura lidar com a singularidade do percurso profissional deste docente, tendo em vista que ele se encontra inserido num contexto de trabalho comum a outros professores. Nessa direção, partimos das características singulares do percurso formativo de três professoras dos anos iniciais do Ensino Fundamental para tentar compreender como acontece o desenvolvimento profissional de professores que atuam na rede pública de ensino no município de São Paulo.

Neste item do capítulo quatro, pretendemos analisar o desenvolvimento profissional de Margareth, Estela e Isabela a fim de que possamos compreender os modos de ser professor na escola pública contemporânea. Para isso, utilizaremos três categorias de análise: relação com o conhecimento, formação contínua e autonomia. As categorias de análise surgem a partir de indexadores que nos auxiliam no momento de realizar a análise do material que colhemos nas entrevistas. Como entrevistamos pessoas diferentes, oriundas de uma mesma carreira - o magistério, necessitamos da elaboração de categorias de análise que dêem conta de agrupar as informações colhidas no momento em que as professoras foram entrevistadas. Sobre isso, Duarte (2004, p. 221) diz que 
a interpretação exige que as unidades de significação (oriundas da fragmentação das entrevistas) sejam articuladas umas às outras a partir de categorias de análise: lembranças de escola, por exemplo, pode ser uma categoria de análise, assim como formação inicial, socialização profissional, gosto etc. Nesse caso, todas as unidades de texto retiradas das falas dos informantes que tiverem relação, por exemplo, com o indexador "lembranças de escola", deverão ser agrupadas sob esse indexador.

Em nossos estudos optamos por estruturar a análise do desenvolvimento profissional de professoras a partir das três categorias já mencionadas anteriormente, que emergiram como lentes privilegiadas para o entendimento do modo como as professoras participantes vivem a docência. Essas categorias, são bastante pertinentes no sentido de que, ao orientar nosso olhar para 'temas específicos' da profissão do professor, temos um ponto de partida para construir a análise sobre o desenvolvimento profissional das professoras entrevistadas. Reiteramos que essas categorias de análise balizarão nosso trabalho a partir de agora.

A ordem com que trataremos cada uma delas não influencia a reflexão que estaremos tecendo ao longo da análise porque relação com o conhecimento, formação contínua e autonomia são faces da mesma moda. Uma categoria está ligada à outra de forma epistemológica e cabe ao pesquisador atribuir sentido àquele mosaico, tendo como referência seus pressupostos teóricos, sua filiação acadêmica, seus objetivos de pesquisa (DUARTE, 2004, p. 222).

\subsection{Relação com o Conhecimento}

A relação com o conhecimento impõe-se como categoria essencial para o entendimento dos modos como se configura a profissão docente na atualidade, pois abarca o 'chão' onde se estrutura o trabalho dos professores. Quando falamos em relação com o conhecimento nos referimos diretamente à relação no sentido de interação, ligação que o sujeito estabelece com o conhecimento. Definir o conceito de conhecimento não é tarefa fácil. Moser (2004), ao estudar a teoria do conhecimento, elenca uma série de explicações a respeito da epistemologia sem se ater a nenhum conceito como universal. Pela dificuldade em encontrar um conceito que abarque o conhecimento de forma geral, total e universal, preferimos ficar com a seguinte afirmação de Gadotti (2007, p. 57): o conhecimento é uma construção social, estruturalmente ligada ao coletivo. Entendemos, também, que o conhecimento é a 
matéria-prima do trabalho do professor. Cada professor utiliza essa matéria prima de acordo com suas experiências pessoais e profissionais.

Piaget $(1978,1979)$ explica que a o desenvolvimento do conhecimento acontece por meio de interação. Isso significa que o conhecimento não se origina no sujeito e nem no objeto, mas sim a partir de relações que se estabelecem ou se criam entre sujeitos e objetos. O que nos importa aqui, não é o conhecimento em si, mas a relação que cada professora estabelece com ele. A relação com o conhecimento não é um fenômeno que acontece somente no ambiente escolar. Ela está presente em todo processo de formação do docente e em todas as facetas da vida desse profissional. Seguindo nessa direção, Cortella (2000, p. 55) coloca que todo educador tem uma interpretação sobre o conhecimento: o que é, de onde vem e como chegar até ele. Ora, essa interpretação nem sempre é consciente e reflexiva e, no mais das vezes, é adotada sem uma percepção muito clara de suas fontes e conseqüências. Vejamos então como nossas professoras se posicionam a respeito dessa relação.

Tanto a professora Margareth, quanto a professora Estela, para além de discorrerem sobre a relação com o conhecimento em si, falam das mudanças que essa relação vem sofrendo ao longo dos anos. A primeira professora diz que sua relação com o conhecimento era mais difícil porque sua formação foi mais teórica e porque os profissionais que ofereceram os cursos pelos quais passou não tinham a experiência em sala de aula pra oferecer a ela. Ela se refere, aqui, ao conhecimento que lhe foi oferecido nos cursos de formação. Na reflexão que Margareth tece sobre sua relação com o conhecimento podemos ver a importância que essa professora atribui ao conhecimento trabalhado nos cursos pelos quais passou. Ela diz ainda que os profissionais formadores ficavam apenas na teoria e não conseguiam fazer uma correspondência com a prática.

Margareth expressa a crítica aos formadores que não conseguem articular suas falas teóricas às demandas da sala de aula. E ela diz que isso mudou: hoje há trocas de experiências e, com isso, o conhecimento vai ser tornando mais produtivo diante dos grupos de trabalho, dos grupos de formação, então melhorou muito. Ao trazer a importância da troca de experiência para os grupos de trabalho e de formação, Margareth coloca que o conhecimento se torna mais produtivo.

Essa professora, ao relatar a importância da troca de experiências, trouxe à tona a questão do espaço que foi criado na jornada de trabalho do professor para que este possa 'trocar experiências' com seus pares e para que haja um momento de 
formação dentro dessa jornada. Aqui podemos perceber claramente o conhecimento em ação. Em outras palavras, quando há um momento em que os professores conversam sobre sua prática na sala de aula, que nada mais é do que sua relação com o conhecimento, eles refletem sobre essa relação. Esse espaço dentro da jornada de trabalho do professor é chamado na prefeitura de Jornada Especial Integral (JEI) e Jornada Especial Ampliada (JEA). Margareth detalha o que acontece nessas Jornadas Especiais: na JEI e na JEA há condições de discutir, de estudar, de saber várias opiniões, as experiências realizadas dentro da unidade, em outras unidades, os cursos, etc. Então abrange um conhecimento maior. Com o passar dos anos e a implementação das jornadas especiais de trabalho do professor a relação com o conhecimento passou a ser diferente.

Perguntamos à Margareth se essas jornadas especiais ajudaram o professor a refletir sobre sua prática pedagógica e se elas passaram a influenciar o trabalho do professor e ela respondeu: com certeza é essencial porque tanto no curso de magistério quanto na universidade, eu não tive todo o embasamento para o meu trabalho. Então foi no dia-a-dia no grupo, nas unidades, que eu fui aprendendo.

Em outro momento da entrevista, quando Margareth contava sobre sua experiência como professora do curso de magistério, ela se lembra que mesmo na época em que trabalhava com o curso de magistério não tratava apenas da teoria, ela gostava de trabalhar a articulação entre teoria e prática. Essa posição está baseada na clareza que tem a respeito dos saberes produzidos na prática: eu acho que complementava o trabalho através dessas experiências porque eu já tinha, na época, uns 10 anos de experiência e uma certa prática pra passar.

No relato acima, a professora demonstra a importância do conhecimento da teoria atrelado ao conhecimento da prática. Margareth conta ainda que ela procurava buscar a prática, mostrar como acontecia. Ela quis que suas alunas tivessem contato com a realidade do dia-a-dia da sala de aula porque não eram apenas os teóricos que poderiam contribuir para a formação dessas alunas, ela - como professora experiente também possuía conhecimentos adquiridos com a prática.

Para Tardif (2005, p. 11) o conhecimento produzido na prática docente é tão importante quanto o conhecimento produzido nos meios acadêmicos:

o saber é sempre o saber de alguém que trabalha alguma coisa no intuito de realizar um objetivo qualquer. Além disso, o saber não é uma coisa que flutua no espaço: o saber dos professores é o saber deles e está relacionado com a pessoa e a identidade deles, com a sua 
experiência de vida e com a sua história profissional, com as suas relações com os alunos em sala de aula e com os outros atores escolares na escola.

Isso ajuda a explicitar os processos de construção do conhecimento, do saber como relação. Conhecimento e saber não são a mesma coisa, epistemologicamente falando, mas assumiremos conhecimento como sinônimo de saber nesse momento de nosso trabalho. Voltando à questão da relação com o conhecimento, concordamos com Tardif (2005, p. 17) quando este diz que as relações dos professores com os saberes nunca são relações estritamente cognitivas: são relações mediadas pelo trabalho que lhes fornece princípios para enfrentar e solucionar situações cotidianas. Sobre isso, Margareth nos apresenta outra faceta de sua relação com o conhecimento ao dizer que

muitas vezes, o professor precisa ser um pouquinho de tudo (mãe, psicólogo, médico, etc.) para conseguir atingir o seu objetivo pedagógico. O professor tem que buscar de qualquer forma, pelo lado que for, alcançar seus objetivos pedagógicos. Ele precisa ir atrás, porque se não, dependendo da sua ação, ele não consegue o resultado no pedagógico porque outras questões, como por exemplo, questões particulares ou outros problemas começam a interferir na aprendizagem.

O relato acima nos remete às questões que podem prejudicar o trabalho refere-se diretamente à relação com o conhecimento. Dito de outro modo, questões de ordem pessoal, social, econômica, etc., podem interferir na ação pedagógica do professor e limitar seu trabalho. Isso soa como uma preocupação por parte de Margareth. Ela diz também que antigamente

a fala era assim "ah, eu ensinei, se o aluno não aprendeu é porque ele não quis, ou porque não tem vontade". E hoje o professor não pode falar isso. Ele não ensina nada se o aluno não quiser. Então não adianta falar 'eu ensinei'. Se o aluno não assimilou, não aprendeu é porque eu não ensinei. Então antes o professor tinha que cumprir o roteiro e acabou. Agora não. A situação é bem outra.

Na mesma direção dos argumentos de Margareth coloca-se Neira (2005,

p. 79) quando diz que

ensino e aprendizagem são considerados indissociáveis, complementares e irredutíveis. Explicamos: antes, ensinar era problema do professor e aprender dos alunos. Ambos os domínios eram considerados, simultaneamente, de modo dissociado, independente ou subordinado. Dissociado, pois o professor poderia ensinar sem que os alunos 
aprendessem. Independente, pois as atividades de ensino se desenvolviam de forma paralela aos esforços dos alunos em aprender de modo suficiente ou insuficiente às exigências dos professores. Subordinado, pois os alunos dependiam da aprovação do professor ou da instituição para prosseguir seus estudos.

O professor de hoje precisa articular o processo de ensino ao processo de aprendizagem: um não existe sem o outro. Essa 'descoberta' trouxe mais qualidade para o ensino e delegou ao professor a necessidade de estar em permanente estado de alerta quanto à relação que seus alunos estão estabelecendo com o conhecimento.

Margareth faz uma declaração muito importante: eu não posso pensar ou preparar uma aula como acontecia na década de 80. A partir dessa declaração, inferimos que seu modo de se relacionar com o conhecimento sofreu modificações, se desenvolveu, alcançou patamares diferentes daqueles do início de sua carreira. E ela conta ainda que

não adianta falar 'eu tenho 23 anos de experiência, eu sei tudo'. De repente eu percebo 'poxa, eu não sabia disso', ou 'eu não sei nada sobre tal assunto'. Eu tenho que buscar, eu tenho que aprender, eu continuo com a mesma vontade embora com dificuldades de tempo por acumular cargo.

O professor da rede pública de ensino em São Paulo, muitas vezes, precisa trabalhar em mais de uma escola para conseguir ter uma renda mais digna e, por isso, lhe falta tempo para se dedicar a sua formação contínua. A professora tem clareza que ainda precisa aprender mais coisas, que existem coisas que ela não sabe. Sobre isso, Tardif (2005, p. 14) diz que

o saber dos professores não é um conjunto de conteúdos cognitivos definidos de uma vez por todas, mas um processo em construção ao longo de uma carreira profissional na qual o professor aprende progressivamente a dominar o seu ambiente de trabalho, ao mesmo tempo em que se insere nele e o interioriza por meio de regras de ação que se tornam parte integrante de sua 'consciência prática'.

Tudo isso nos ajuda a vislumbrar o processo de desenvolvimento profissional de Margareth.Vamos agora às percepções de Estela. Essa professora conta como foi sua aproximação com o universo do conhecimento:

o conhecimento vem comigo desde a escola, como aluna. E sempre foi assim: o professor tem todo o conhecimento e transmite tal qual para o aluno. Na experiência mesmo, no dia-a-dia é que eu aprendi que não é assim que funciona. Que na verdade o conhecimento é produzido a cada dia e sempre na prática. Ele não vem da teoria, a teoria é que vem 
esclarecer, vem justificar, vem trazer o argumento pra prática, mas na verdade o conhecimento é produzido, ele só existe se ele for apropriado por você, assimilado, apreendido.

Essa fala de Estela nos remete a Cortella (2000, p. 104), quando diz que o conhecimento é fruto da convenção, isto é, de acordos circunstanciais que não necessariamente representam a única possibilidade de interpretação da realidade. Isso é perfeitamente verificável quando a professora em questão fala que no dia-a-dia é que ela aprendeu que não é assim que o conhecimento funciona. Em outras palavras, Estela coloca que há diferentes possibilidades de se lidar com o conhecimento e que ele é fruto das experiências, das convenções, da formação e das circunstâncias que o contextualizam. Nessa mesma direção, Camargo (2004, p. 9) sugere que não existe um método ou uma receita mágica para a aquisição do conhecimento, pois esta depende de atitudes, interesses, objetivos, posicionamentos tanto individuais como coletivos.

Estela afirma que foi com as Classes de Aceleração, em 1996, que ela teve consciência de que o conhecimento era produzido a cada dia e sempre na prática. Foi com os alunos que apresentavam defasagem entre a idade que possuíam e a série em que estavam que essa professora percebeu que o trabalho com o conhecimento precisava ser construído junto aos alunos. Essa defasagem acontece porque o aluno que não consegue alcançar os requisitos mínimos para ir para a série seguinte, fica vários anos na mesma série. Ela conta em detalhes como foi essa experiência:

os alunos já tinham passado pela transmissão de conhecimento na primeira, segunda, terceira e quarta séries. Eles tinham - no mínimo de quatro a cinco anos de escolarização. Vários professores tentaram passar o conhecimento, transmitir o conhecimento e não conseguiram. Com o projeto de Aceleração - que no começo era muito bem elaborado, tinha respaldo, subsídio e material didático - o conhecimento não foi o livro que trouxe. Foi a formação mesmo. As crianças descobrindo como que eles aprendiam. Eles aprendiam na brincadeira, eles aprendiam no fazer horta, eles aprendiam no ler jornal, no rasgar jornal, na hora de fazer papel marchet, etc. Então eles aprenderam. Nessa época eu já percebia que alguns tinham habilidades pra algumas coisas, mas tinham que desenvolver competência pra outras habilidades.

Estela foi convidada para trabalhar com o projeto do governo estadual das Classes de Aceleração e depois passou a ser formadora de professores na Oficina Pedagógica. A formação pela qual Estela passou ao participar desse projeto, levou-a a experimentar diferentes ações didáticas que possibilitaram aos alunos se apropriar de conceitos, de informações e a produzir conhecimento. A partir dos resultados 
alcançados com esses alunos, a professora foi reformulando suas concepções e modos de se relacionar com o conhecimento. Sobre isso, Camargo (2004, p. 41) coloca que sendo o conhecimento o resultado de um processo da vida da pessoa, que por sua vez faz parte de uma sociedade cheia de vicissitudes, ele adquire tipos, formas ou graus diferentes, a partir das fontes que o produzem, das faculdades humanas usadas, das necessidades que o exigem, enfim de todo um contexto histórico.

O contexto - tanto histórico, quanto social, intelectual, didático, etc. influencia diretamente o processo de construção, apropriação, produção do conhecimento. Por isso, entendemos, de acordo com o relato de Estela, que a partir do momento em que o professor oferece ao aluno outras formas de se lidar com o conhecimento, o aluno consegue alcançá-lo. Ela explicita suas convicções da seguinte forma:

Eu acredito muito nos estudos de Vygotsky, na zona de desenvolvimento proximal. E acredito que a criança, quando vem para a escola, já sabe algumas coisas. Pra ela ser uma pessoa melhor, ela tem que aprender outras coisas. É aí que está o papel do professor: aproximar o que a criança tem potencialidade de saber, daquilo que ele já sabe e transformar isso num conhecimento, numa sabedoria melhor.

O conceito de zona de desenvolvimento proximal (VYGOTSKY, 2000) relaciona-se com a diferença entre o que a criança consegue aprender sozinha e aquilo que consegue aprender com a ajuda de uma pessoa que saiba mais que ela. Temos aqui a idéia do conhecimento como ação que necessita de movimentação para poder produzir frutos.

Falando um pouco mais sobre sua relação com o conhecimento, Estela descreve como planeja suas atividades:

E mesmo planejar, por exemplo, eu sempre fui voltada para atender a criança, perceber o que ela pode me dar, e planejar a partir daí. Ultimamente estou direcionando minha atenção para as orientações dos PCNs, para algumas coisas dos autores que eu já li: me preocupo mais com a psicogênese da escrita, com aquilo que Wallon falou sobre afetividade. Na hora de planejar, eu procuro levar em consideração tudo isso. No começo era assim: a criança não sabe isso, ela precisa aprender aquilo e eu vou ensinar isso. Agora, quando eu preparo uma atividade, eu presto atenção pra ver se isso aqui vai atender um número maior de crianças, quais são as crianças que eu já avaliei que vão ou não vão conseguir fazer, realizar; para qual criança aquilo é um desafio, ou pra qual criança aquilo vai ser fácil de fazer, fácil de resolver. Então quando eu preparo a atividade, eu já vou pensando no tipo de desafio que eu vou oferecer para as crianças. 
Aqui está claramente exposta a relação de Estela com o conhecimento e a forma como ela planeja as atividades para que seus alunos as realizem de um modo que seja proveitoso e prazeroso para eles. Ela entende que os alunos apresentam ritmos diferentes de aprendizagem, então, de acordo com isso, ela precisa estabelecer desafios variados para esses alunos, para que eles se sintam instigados a participar das atividades. Estela menciona ainda alguns estudos que a auxiliam nesse processo de planejamento: os PCNs, a psicogênese da escrita e as idéias de Wallon. Quando essa professora fala da psicogênese da escrita, ela está se referindo aos estudos de Emilia Ferreiro e Ana Teberosky (2006), nos quais ambas as autoras procuraram observar como se realiza a construção da linguagem escrita na criança. Ferreiro e Teberosky afirmam que quando o professor conhece a maneira como a criança concebe o processo de escrita, as teorias pedagógicas e metodológicas podem apontar caminhos a fim de evitar os erros mais freqüentes daqueles que alfabetizam: que a criança não tem 'prontidão' para se alfabetizar, que ela apresenta problemas familiares que interferem nesse aprendizado, que tem problemas cognitivos, que por não se alimentar direito não vai conseguir se desenvolver intelectualmente. Para as autoras toda criança é capaz de se alfabetizar num processo de construção da escrita e da leitura.

Ao se referir aos Parâmetros Curriculares Nacionais (BRASIL. SECRETARIA DE ENSINO FUNDAMENTAL, 1997), Estela demonstra que o utiliza como um norte para o planejamento de seu trabalho. Ela não segue à risca o que é ali proposto, até porque o documento em questão apresenta diretrizes gerais de trabalho com o conhecimento e não se configura como uma 'camisa de força' para o trabalho do professor. Quando se refere aos estudos de Wallon, ela parte do princípio que este autor considera as emoções como a primeira ferramenta de interação com o meio que uma criança possui. Por exemplo, um bebê não tem condições de satisfazer suas necessidades sozinho e nem consegue estabelecer uma linguagem para se comunicar com o adulto, por isso ele chora. Wallon considera este o primeiro passo do estabelecimento gradual, pela criança, de relações entre seus atos e seu meio. Este autor atribui às emoções o papel preponderante no desenvolvimento da criança. Para ele, é por meio das emoções que a criança exterioriza seus desejos e suas vontades. A abordagem de Wallon é sempre a de considerar a criança como um todo. Elementos como afetividade, emoções, movimento e espaço físico se encontram num mesmo plano e influenciam diretamente o desenvolvimento da criança (WALLON, 1989 e 2005). 
Falando ainda sobre os autores que orientam seu trabalho, Estela conta que só foi dar credibilidade à Emília Ferreiro quando leu também o Piaget. Isso mostra que essa professora procura saber até que ponto as contribuições de um determinado autor são válidas ou não para conseguir melhorar seu trabalho com os alunos. Ainda nessa temática dos estudos que auxiliam o trabalho pedagógico em sala de aula, a professora foi fazer graduação em matemática para tentar compreender por que os alunos tinham tanta dificuldade em matemática:

eu fui fazer justamente por ter ido trabalhar na aceleração e as crianças terem tanto ódio ou tanto medo de matemática. Então, eu falei 'gente eu quero saber o que é que acontece'. Então fui fazer curso de matemática. A faculdade foi bastante interessante, mas não me ajudou a solucionar isso.

O processo relatado ajuda a evidenciar os modos como Estela foi encaminhando seu desenvolvimento profissional na relação com o conhecimento. Isso é perceptível principalmente quando a professora se refere à forma como planejava suas atividades no começo da carreira e como planeja hoje e ao que leva em consideração no momento do planejamento. Essa visualização também se mostra quando essa professora discorre sobre os autores e os estudos que auxiliam seu trabalho pedagógico. Estela, ao trabalhar com contos de fadas, parlendas, músicas, ela aproveita os contos de fadas, a estrutura dos contos de fadas para trabalhar gramática. E diz ainda que essa prática é muito contrária a prática do começo, em 1992, porque ela partia da gramática para o texto e hoje não, ela prioriza a estrutura textual. Em outras palavras, os objetivos de seu trabalho pedagógico, depois de quase quinze anos de docência, são diferentes dos objetivos do início de sua carreira, demonstrando, assim, seu desenvolvimento como professora.

O desenvolvimento profissional de Estela também se verifica no relato abaixo, quando trata da indissociabilidade entre ensinar e aprender:

O papel do professor sempre foi ensinar. Quando eu entrei em 1992, o professor entrava na sala de aula, ensinava e supunha que os alunos aprendiam. Então assim: eu vou fazer meu papel, vou lá ensinar, vou dar o silabário todinho. Chegava no final de outubro eu terminava o livro. Chegava em novembro eu terminava o conteúdo e tinha ensinado. Era o papel do professor. A partir de 1994, 1995, 1996 a concepção do ensinar mudou, a concepção do papel do professor mudou. O professor começou a atrelar o ensinar com o aprender. O professor só ensina se alguém aprende. Se alguém não aprendeu, ele não ensinou. 
A complexidade das relações pedagógicas frente a esse paradigma da indissociabilidade entre ensino e aprendizado delega ao professor maior responsabilidade no momento de preparar o planejamento das atividades que vai oferecer aos alunos. Essa maior responsabilidade se configura a partir do estabelecimento da necessidade de se acompanhar o desenvolvimento do aluno para avaliar se este está alcançando os objetivos propostos pelo professor.

Diante do depoimento de Estela, compreendemos que o modo de ser professor vem se transformando ao longo dos anos. Isso indica que o desenvolvimento profissional é um processo contínuo, ininterrupto e que se articula com as demandas que aparecem no contexto escolar.

Vejamos agora como Isabela, a professora com menor tempo de experiência docente - apenas três anos, evidencia sua relação com o conhecimento. Para ela o conhecimento

é muito importante porque é através dele que você se desenvolve tanto na sua vida pessoal quanto na vida profissional. Ele é importante porque a pessoa não pode ser passiva no mundo, só receber as informações, só receber o que os outros produziram e não produzir nada. Quando você produz o conhecimento é porque você internalizou alguma coisa e você aprendeu. Você saiu de um estágio de conhecimento e chegou a outro.

Esse processo de internalização é explicado por Camargo (2004, p. 16):

conhecer é apropriar-se de um objeto mentalmente a partir do contato com os sentidos; a faculdade básica do conhecimento é a inteligência que, etimologicamente, deriva de intus (dentro) e legere (ler): por ela, a pessoa lê dentro do objeto e extrai o que ele significa, trazendo-o imaterialmente para dentro de si.

Internalizar é trazer um objeto imaterialmente para dentro de si. É um processo de produção de conhecimento onde a pessoa extrai de um objeto o que há de significativo para si e a partir dessa produção, passa a estabelecer relações com outros objetos. Nesse sentido, Hessen (1980) afirma que o conhecimento só começa a existir a partir do estabelecimento de uma relação e correlação.

Perguntamos à Isabela como se dá sua relação com o conhecimento na escola e ela nos relatou o seguinte:

Na escola, a minha relação com ele ocorre quando eu proponho as atividades para os meus alunos das séries iniciais e das séries finais do Ensino Fundamental. Quero que os alunos não sejam meros copistas. Não gosto de fazê-los copiar texto da lousa, ou colocar aquelas questões em que o aluno tem apenas que selecionar o que está escrito no texto, 
sem ter que inferir nada, que fazer nenhum entendimento. Eu não costumo passar atividades desse tipo e eles até reclamam muito comigo. Eu quero que os alunos entendam o que está lá e eu coloco questões nos exercícios que eles tenham que pensar o texto, não apenas que eles tenham que fazer perguntas de localização de respostas. Que eles tenham que pensar porque a partir dali é que eles vão produzir conhecimento. Quando eles fazem atividade de produção de texto, eu não dou tema livre porque tema livre é muito vago. $O$ aluno que tem dificuldade, vai ficar com mais dificuldade ainda. Então geralmente eu dou uma orientação. "olha, vai ser uma dissertação sobre a questão das armas ilegais no país”. Aí geralmente eu trago um texto, um poema, alguma coisa que dá um norte para o aluno fazer. Então a partir daí ele também vai produzir o conhecimento.

E os alunos do fundamental I, da alfabetização, eles também....eu também não deixo que eles fiquem só copiando resposta da lousa porque eu falo para todos que só copiar não aprende. Porque até um analfabeto copia. Então não aprende. E eu vejo que na escola, ainda, há muitos professores que acham que a cópia é o melhor método.

Esse relato nos fornece indícios importantes sobre como a professora se relaciona com o conhecimento e como tenta construir uma relação com seus alunos permeada por oportunidades de produção de conhecimento. Machado (1996, p. 27), em seu estudo sobre epistemologia e didática, afirma que o discurso pedagógico e as ações docentes são permanentemente tributários de uma concepção do conhecimento e da dinâmica dos processos cognitivos. Diante disso, entendemos que Isabela, assim como a professora Estela, apresenta uma concepção de conhecimento que nos remete ao conceito de zona de desenvolvimento proximal de Vygotsky (2000) onde o aluno é sujeito da ação de produção de conhecimento e deve ser estimulado a se envolver nessa ação por um adulto ou por alguém que saiba mais que ele.

A zona de desenvolvimento proximal refere-se a tudo o que a criança pode adquirir em termos intelectuais quando lhe é dado o suporte educacional devido. Vygotsky considera que há duas zonas de desenvolvimento: a real (o que a criança já sabe) e a potencial (o que a criança pode passar a saber). Diante disso, ele afirma que a aprendizagem gera o desenvolvimento porque a criança, a partir da influência do meio no qual vive, parte do que já sabe e se impulsiona rumo a um novo conhecimento. Há uma potencialidade de aquisição de novos conhecimentos em movimentação. Através da aprendizagem a criança se desenvolve.

Tendo em vista o que propõe Vygotsky, podemos entender que quando Isabela propõe atividades sobre as quais os alunos tenham que pensar, porque a partir dali é que eles vão produzir conhecimento, ela parte do pressuposto que $o$ aluno 
incorpora os conhecimentos científicos ao reinterpreta-los pessoalmente e reconstrói seus esquemas e preconcepções ao incorporar novas ferramentas intelectuais de análise (NEIRA, 2005, p. 62). O aluno precisa estar envolvido na atividade pedagógica para que possa apreender e internalizar informações contidas nessa atividade num processo de construção de conhecimento. Além disso, o trabalho desenvolvido pelo professor deverá encaminhar o processo de reconstrução, estimular o desenvolvimento na criança e no adolescente da capacidade de compreensão, de reorganização racional e significativa da informação reconstruída (NEIRA, 2005, p. 66).

Continuando o depoimento sobre sua relação com o conhecimento, Isabela coloca algumas preocupações que perpassam sua ação na sala de aula:

na minha primeira série, $90 \%$ da sala ainda não conhece o alfabeto. $O$ aluno tem que conhecer a base alfabética, se ele ainda não conhece, o professor vai planejar atividades para que ele domine a base alfabética. Esse é o primeiro passo para aprender a ler e a escrever.

Essa afirmação de Isabela demonstra seu domínio sobre os objetivos do primeiro ano, o que não acontecia quando ela iniciou sua carreira em 2004. Demonstra também seu movimento no campo das atribuições implícitas à docência, como o estabelecimento dos objetivos a serem alcançados na fase da alfabetização. Sobre essa questão da alfabetização, ela nos diz mais:

Eu achava que não tinha mais idéia para fazer atividades diversificadas como lista de palavras, produção de texto coletivo com o professor como escriba e fui tentar trabalhar o Ba-Be-Bi-Bo-Bu. Eu vi que o $\mathrm{Ba}-\mathrm{Be}-\mathrm{Bi}$ $\mathrm{Bo}-\mathrm{Bu}$ não tem sentido nenhum. O aluno que aprende o $\mathrm{Ba}-\mathrm{Be}-\mathrm{Bi}-\mathrm{Bo}-\mathrm{Bu}$ é aquele que aprende o construtivismo fácil. $\mathrm{O}$ trabalho com o $\mathrm{Ba}-\mathrm{Be}-\mathrm{Bi}$ Bo-Bu começa com aquelas palavras sem sentido, o aluno não percebe aquilo, aquilo é uma decoreba. Então os alunos que têm facilidade para decorar, memorizar, eles aprendem com aquilo, mas e os outros que precisam refletir sobre a escrita? Porque a aquisição da escrita é muito complicada. É o processo mais complicado na escolarização porque quando o aluno adquire a escrita e a leitura, ele pode ter sucesso em qualquer disciplina. Agora o aluno que não adquiriu bem a questão da leitura e da escrita, que não entende o que lê, que escreve tudo junto, com muitos problemas de segmentação, de ortografia, de escrever mesmo as palavras e o que elas representam, eles vão ter dificuldade nas outras disciplinas.

Com estas considerações a professora evidencia as bases que sustentam sua atuação. Lembramos que ela participou, em 2004, de um curso de formação contínua oferecido pela Prefeitura de São Paulo denominado PROFA - Programa de Formação de Professores Alfabetizadores, que influenciou diretamente sua prática como 
professora alfabetizadora e impulsionou seu desenvolvimento profissional, na medida em que ajudou-a a sair de um patamar de conhecimento (deficiência em lidar com a alfabetização) para chegar a outro patamar, que lhe possibilitou ter uma atuação pedagógica mais condizente com as necessidades dos seus alunos.

Isabela nos fornece outras pistas nessa direção:

eu não tinha ainda noção do que o aluno tinha que aprender em cada série do Ciclo I do Ensino Fundamental. Hoje eu tenho porque, como eu peguei a primeira série, e eu já tinha feito o PROFA, eu pude analisar melhor alguns livros didáticos pra ver o que cada um propunha, qual a base teórica de cada um, que vem no PNLD, no Plano Nacional do Livro Didático. Eu também tive uma orientação esse ano [2006] no Programa Ler e Escrever da Prefeitura de São Paulo. Essa orientação veio num livrinho para as escolas, para os professores. Ele trazia quais as competências que o aluno tem que ter em português e matemática ao final de cada ano do Ciclo I. Então na primeira série, ele tem que aprender até tal coisa, por exemplo, em matemática, o aluno tem que aprender usar, calcular tudo até o número 99, que ele só vê unidade e dezena na primeira série. Então eu sei que na primeira série, em matemática, eu vou trabalhar o conceito de unidade e dezena e as atividades e os desafios nesta questão. E também a questão, por exemplo, da adição na primeira série. Somente no final do ano é que o professor vai iniciar aquele cálculo que a gente chama de 'vai um'. Quando a unidade passa de nove e tem que dar, emprestar, passar um número pra casinha da dezena. Isso é só no final da primeira série porque isso vai ser desenvolvido na segunda. E as mesmas coisas com as contas de subtração, por exemplo, na primeira série não tem o reagrupamento, que é o que a gente chama de emprestar, quando um número empresta para o outro. Isso é na segunda série.

Vemos aqui alguns marcos significativos do seu processo de desenvolvimento: o curso do PROFA em 2004 e as orientações do Programa Ler e Escrever em 2006. O primeiro marco demonstra um salto em qualidade nas questões de alfabetização e o segundo nas questões sobre a matemática. A idéia de que o desenvolvimento profissional é indissociável da formação contínua e da prática em sala de aula fica aqui corroborada.

E Isabela, mais uma vez, deixa clara a sua consciência frente ao seu aprendizado e ao seu desenvolvimento como professora:

antes de falar do planejamento da aula, vou falar do planejamento desse ano. Eu tive uma maior noção porque já era o meu terceiro ano tanto na rede municipal, quanto na estadual, então eu já tive uma idéia sobre o que eu queria desenvolver com cada turma em cada bimestre. 
Novamente voltamos à Tardif (2005, p. 39), quando diz que os próprios professores, no exercício de suas funções e na prática de sua profissão, desenvolvem saberes específicos, baseados em seu trabalho cotidiano e no conhecimento de seu meio. Esses saberes brotam da experiência e são por ela validados. Quando Isabela fala que 'já teve uma idéia' sobre o que ela queria desenvolver com os alunos, ela utiliza esse saber que vem da prática para planejar seu trabalho.

Os relatos das três professoras nos apresentam indicativos sobre a relação que elas estabelecem com o conhecimento. Através desses relatos podemos aferir que a relação pedagógica vincula o professor ao aluno por meio do conhecimento. Até porque, como dissemos anteriormente, o conhecimento é a matéria-prima do trabalho do professor.

Os depoimentos nos ofereceram informações sobre modos de planejar a aula, de escolher os objetivos de acordo com a realidade dos alunos, de avaliação do trabalho do professor, etc. As professoras discorreram sobre seu processo de formação e sobre como dão conta das tarefas docentes. Isso nos possibilitou analisar os modos como cada uma delas vem conduzindo seu desenvolvimento profissional.

Vimos que as duas professoras com maior tempo de carreira, Margareth e Estela, demonstram que agora é impossível separar o processo de ensino do processo de aprendizagem e que antes essa separação acontecia. A professora mais jovem - tanto em termos de idade, quanto de experiência docente, Isabela, também traz em suas falas a questão dessa indissociabilidade. Durante a década de 80 e o começo da década de 90 , o professor acreditava que ao ensinar, o aluno aprendia e que não havia necessidade de se conferir se o ensinar estava articulado com o aprender. Com a experiência adquirida ao longo dos anos e das vivências na carreira, Margareth e Estela se deram conta de que havia uma nova demanda para o trabalho do professor: articular o ensino com a aprendizagem. Essa constatação nos leva a crer que essas professoras puderam ter essa noção de que o ensino e a aprendizagem se tornaram indissociáveis através de seus processos de desenvolvimento profissional. Dizemos isso porque houve uma transformação do paradigma do principal elemento do trabalho do professor: o ensino. $\mathrm{O}$ ensinar passou a estar atrelado ao aprender. Um inexiste sem o outro. Fica-nos a interrogação sobre quando aconteceu a mudança desse paradigma, mas, temos uma hipótese que pode explicar essa mudança: a implantação do regime de ciclos nas escolas públicas da rede municipal (1992) e da rede estadual (1998) de São Paulo. 
Esse tipo de organização do ensino trouxe outras formas de se pensar a aprendizagem, a avaliação, o desempenho dos alunos, etc. As concepções de tempo e espaço na escola assumem outra configuração. Há a necessidade de dar continuidade ao processo de ensino e aprendizagem entre os anos letivos. Os professores precisam avaliar os alunos de modo contínuo e formativo. $\mathrm{O}$ aluno que não consegue alcançar êxito em seu processo de aprendizagem e desenvolvimento demanda um acompanhamento mais atento por parte do professor porque não é mais a nota que está em questão e sim quais competências aquele aluno vem adquirindo ao longo do ano letivo através do trabalho do professor e como o trabalho do professor pode ajudar aquele aluno a avançar na sua relação com o conhecimento. $\mathrm{O}$ regime de ciclos estabelece paradigmas diferentes para o trabalho com o conhecimento na escola e o professor é o principal agente dessa mudança.

A análise das entrevistas das professoras Margareth, Estela e Isabela nos forneceu informações importantes sobre os modos como elas lidam com o conhecimento. Na medida em que as professoras foram explicitando as mudanças de atitudes e pensamentos ao longo das diferentes situações pedagógicas que foram surgindo no dia-a-dia da sala de aula, foi se revelando os modos como o desenvolvimento profissional de cada uma delas foi se efetivando.

Vejamos agora como essas professoras se relacionam com sua formação contínua.

\subsection{Formação Contínua}

Partimos do princípio que a formação contínua influencia diretamente o desenvolvimento profissional do professor e é por ele influenciada. Não há como se desenvolver profissionalmente sem se formar. Não há desenvolvimento sem formação e nem formação sem desenvolvimento. Uma coisa leva à outra.

Canário, refletindo sobre a formação baseada em pesquisas de biografias educativas, coloca que essas pesquisas

evidenciam o caráter reflexivo e apropriativo dos recursos individuais de formação, daí os processos de desenvolvimento pessoal e de desenvolvimento profissional aparecerem como indissociáveis[...] Isso implica que a formação seja entendida como um recurso pessoal em que cada um, tomando como base a sua experiência vivida, no contexto de uma coletividade, confronta experiências, apropria-se de informações, constrói saberes, numa lógica de desenvolvimento e não de ruptura com o seu passado profissional (CANÁRIO, 1994, p. 64-65). 
É na direção apontada por Canário que caminhamos a partir de agora. Procuramos analisar, através das informações colhidas nas entrevistas de Margareth, Estela e Isabela, como acontece o processo de formação contínua de cada uma delas na perspectiva de visualizar os passos orientadores de seu desenvolvimento profissional.

Entendemos que não há como separar os itinerários de formação das trajetórias de vida. Os acontecimentos da vida pessoal e profissional apontam os caminhos para a formação. Bolívar (2002, p. 99) coloca que a formação contínua para ser significativa requer que cada adulto compreenda, se aproprie de sua própria formação e a reconstrua a partir de sua história de vida. Esse autor trabalha com a idéia de que os processos de formação e as histórias de vida dos sujeitos não são independentes entre si. Para ele, o formar-se carrega em si uma estreita ligação entre a história de vida e as experiências e saberes que as pessoas mobilizam em sua formação.

Ancoradas nesse entendimento, buscamos em Marcelo Garcia (1994, p. 314) referências para o entendimento da formação contínua. Para esse autor ela se refere a toda

actividad que el profesor en ejercicio realiza con una finalidad formativa - tanto de desarrollo profesional como personal, de modo individual o en grupo - que tienda a una más eficaz realización de sus actuales tareas o le preparen para el desempeño de otras nuevas.

Desse modo, a formação contínua é condição sine qua non para que o desenvolvimento profissional possa acontecer. Vejamos então como as professoras participantes da pesquisa se posicionam a respeito desse tema.

Margareth, a professora com maior tempo de experiência docente, fala que em 1986 - seu segundo ano como professora eventual na rede estadual começaram a ser ministrados pela CENP - Coordenadoria de Estudos e Normas Pedagógicas - os cursos a respeito da proposta de alfabetização formulada por Emília Ferreiro. Vemos aqui a preocupação da Secretaria Estadual de Educação em proporcionar aos professores em exercício uma formação que lhes possibilitassem refletir sobre a alfabetização. Houve, nessa iniciativa, um incentivo institucional para a formação contínua do professor.

Continuando a rememorar os cursos que realizou durante a carreira, Margareth coloca que não conseguiu fazer o Letra e Vida na rede estadual e nem o PROFA na rede municipal porque não teve tempo devido ao acúmulo de cargos como professora. Ambos os cursos citados seguem a linha de orientação dos estudos de 
Emília Ferreiro, Ana Teberoski e Telma Weisz a respeito da aquisição da língua escrita, apresentam questões pertinentes ao trabalho com a alfabetização, propõem a realização de atividades com os alunos e levam o professor a refletir sobre sua prática de alfabetização. O Letra e Vida e o PROFA são iniciativas institucionais que viabilizam a formação contínua do professor alfabetizador visando à melhoria da prática educativa e ao êxito do trabalho do professor com os alunos em processo de alfabetização.

Tanto Margareth, quanto Estela e Isabela, por estarem atuando em 2006 no primeiro ano do Ensino Fundamental em escolas municipais, tiveram que fazer a formação do Programa Ler e Escrever - Prioridade na Escola Municipal (SÃO PAULO, 2005). Esse Programa foi instituído pelo governo de José Serra (PSDB) e teve continuidade no governo de Gilberto Kassab (DEM). Elaborado sob a supervisão da secretária-adjunta de Educação Iara Glória Areias Prado, esse programa propõe-se a fortalecer a prática dos professores alfabetizadores para que todos os alunos se alfabetizem durante o Ciclo I.

Em agosto de 2005 a Diretoria de Orientação Técnica da Secretaria Municipal de Educação publicou o documento "Orientações Gerais para o Ensino de Língua Portuguesa no Ciclo I". O trabalho é um esforço no sentido de subsidiar e dar referências à elaboração dos planos de ensino da língua portuguesa nos quatro anos do Ciclo I do Ensino Fundamental - organizando o ensino em etapas, de forma a distribuir entre os professores dos quatro anos a responsabilidade pela aprendizagem dos alunos. O documento procura, ainda, orientar a escolha de materiais didáticos e a construção de indicadores de avaliação para os diversos anos do Ciclo I. Como estratégia, o que se propõe é a divisão desse esforço em três projetos:

- $1^{\mathrm{o}}$ Toda Força ao $1^{\mathrm{o}}$ Ano do Ciclo I (TOF): voltado para alunos e professores do primeiro ano do Ciclo I, para que ao final do ano letivo nenhuma criança tenha dificuldades para ler e escrever;

- $2^{\mathbf{o}}$ Projeto Intensivo no Ciclo I (PIC): com classes especiais de recuperação, onde os alunos que não se alfabetizaram ao longo dos três primeiros anos do Ciclo I possam se alfabetizar a partir de estratégias diferentes de aprendizagem no quarto ano;

- $3^{\text {o }}$ Ler e Escrever em todas as áreas do Ciclo II, para elevar a competência para ler e escrever dos alunos do Ciclo II.

O Projeto "Toda Força ao $1^{\circ}$ Ano do Ciclo I" (TOF) foi elaborado com objetivo de criar condições adequadas para garantir a aprendizagem da leitura e da 
escrita a todos os alunos ao final do primeiro ano do Ciclo I. Para isso, todos os professores que assumiram salas de primeiro ano e que se enquadravam na Jornada Especial Integral (40 horas aula/semana) ou na Jornada Especial Ampliada (30 horas aula/semana) foram convidados a fazer a formação do TOF. A formação do projeto TOF só é 'obrigatória' para os professores que trabalham em JEI ou JEA, os professores que optaram pela Jornada Básica (20 horas aula/semana) não participam do curso. Além da formação em nível de Coordenadoria de Educação, o curso do TOF contava também com a continuação dessa formação na própria escola através do Coordenador Pedagógico. Como estímulo à adesão ao programa, os professores participantes dessa formação terão pontuação diferenciada para fins de evolução funcional, desde que permaneçam em regência na classe durante todo o ano letivo e alcancem os objetivos propostos.

Podemos observar, a partir do que foi exposto sobre o Programa Ler e Escrever - Prioridade na Escola Municipal, que a SME demonstra preocupação para com a formação dos professores alfabetizadores, visto que a alfabetização ainda apresenta índices não satisfatórios na rede municipal de ensino.

Vejamos agora as impressões de Margareth, Estela e Isabela sobre o projeto TOF.

Sobre o TOF, eu acredito que houve uma falha. Eu acho que o curso do TOF veio atrasado porque aconteceu somente agora no início do segundo semestre, sendo que nós já estamos dentro da tal proposta desde o primeiro dia do ano letivo. (Professora Margareth)

O curso é aquele formato: faça o que eu falo, mas não faça o que eu faço. $O$ curso do TOF é horrivel. Horrivel, pavoroso, é chato. $O$ professor não é levado a pensar, é mal acolhido, está mal acomodado. Nem chega a ser um treinamento. É só pra cumprir horas. É cumprir horas de um curso. Você chega num lugar onde as acomodações não são as mais adequadas, quando você enxerga o cartaz você não enxerga o orador. O material nunca é suficiente. Mesmo o livro do TOF, nós estamos em meados de setembro e eu ainda estou com o segundo volume que terminou antes do mês de agosto. Então o livro que vem pro terceiro bimestre ainda não chegou. E quando chega, ele tem que ser preenchido. O curso tem aquela coisa assim impositiva, você tem que trabalhar isso, fazer aquilo.

O curso do TOF está me ensinando o seguinte: "isso aqui você não faz. com seu aluno porque ele não vai te suportar". O aluno vai ficar muito chateado se ele tiver que fazer desse jeito. Então a contribuição é essa. Se você ficar na frente lendo em voz alta para as outras crianças, as crianças vão fazer aquilo que os professores fazem lá no curso: virar a cadeirinha e conversar um com o outro e a pessoa que fica lendo lá na 
frente fica lendo lá na frente. Está lendo pra ela mesma. Então essa é a contribuição do curso: isso você não deve fazer com as crianças. (Professora Estela)

O curso do TOF tem um problema: a má formação dos próprios formadores do curso. São professores designados pra trabalhar na Coordenadoria de Educação e boa parte deles não tem experiência com alfabetização. Como é que você vai dar uma formação para alfabetizadores se você não sabe do que se trata? Os próprios formadores do curso têm uma formação na Diretoria de Orientação Técnica, só que eles não têm a experiência para poder saber o que dá e o que não dá certo. Então eles acham que tudo que é passado é possível ser aplicado na sala de aula pra resolver todos problemas. E não é. Então esse é o grande problema. E outra coisa que eu percebo no curso do TOF é que não é um momento pra você refletir, discutir sobre as questões da alfabetização, é um momento pra você se enquadrar ao programa. Você tem que se enquadrar, você não pode refletir. Você não pode questionar. Você tem que se enquadrar ao que eles estão propondo, então isso é ruim porque não é o momento para reflexão. O que nós estávamos achando no começo é que nós íamos trocar experiências, "ah, mas eu fiz tal atividade com o aluno e funcionou" e ter formação assim: trazer teoria que embasasse essas nossas discussões, essas nossas reflexões. Só que nós não conseguimos refletir. Muitas vezes nós começamos a questionar e somos interrompidos porque tem que seguir a pauta porque não vem ao caso a pergunta em questão. A maioria dos professores que está fazendo o curso está descontente porque o anseio era a troca de experiências, a reflexão, e não é isso que acontece. Você tem que se enquadrar ao programa. Essa é minha crítica ao programa. (Professora Isabela)

As três professoras trazem críticas ao curso de formação do projeto "Toda Força ao $1^{\text {o }}$ Ano do Ciclo I" oferecido pela Coordenadoria de Educação. Margareth, Estela e Isabela fizeram esse curso pela Coordenadoria de Educação de Itaquera - Zona Leste de São Paulo.

De posse dos três relatos, fica clara a insatisfação das professoras diante do curso de formação que foi oferecido para os profissionais que optaram por participar do projeto "Toda Força ao $1^{\circ}$ Ano do Ciclo I". Essa formação contínua de origem institucional não levou as professoras, segundo seus próprios relatos, a refletirem sobre o que estavam estudando. Acreditamos que os anseios dos professores precisam ser levados em conta na hora de se formular uma ação formativa porque

é importante ressaltar que a formação contínua precisa ser considerada na perspectiva do desenvolvimento profissional dos professores, articulada com suas necessidades e com as das escolas, propiciando retorno no âmbito da produção de saberes e da intervenção profissional. Portanto, a formação contínua está articulada com a mudança nas 
escolas, com a realização do trabalho dos professores, com os projetos escolares. Se a formação oferecida não se constituir numa resposta adequada ao conjunto das necessidades dos professores, representará um desperdício de recursos e de tempo, onde perdem os professores, os alunos e o próprio sistema, enfim (ALMEIDA, 1999, p. 207).

A experiência de formação contínua vivenciada através do curso do TOF mereceu destaque em nossa análise porque as três professoras passaram por ele e porque ele foi uma das mais recentes iniciativas do governo municipal em relação à formação dos professores da Rede Municipal de Ensino de São Paulo. Esse curso também foi oferecido aos professores municipais também no ano de 2007.

Mesmo com as falhas apontadas, entendemos que o curso do TOF contribuiu para o desenvolvimento profissional de Margareth, Estela e Isabela porque se mostrou como um espaço de formação que propiciou o desenvolvimento da percepção crítica sobre os modos de realizá-la, bem como sobre as necessidades sentidas pelas professoras nesse campo. Elas se deram conta de que seus anseios caminham em direção diferente àquela colocada pelo curso. As críticas feitas pelas professoras indicam o desenvolvimento de uma consciência intelectual importante e propiciaram espaço para que elas formulassem suas idéias a respeito da avaliação do que foi trabalhado no curso em relação às suas práticas nas salas de aula. Dito de outro modo, Estela e Isabela foram para o curso esperando momentos de reflexão coletiva sobre as experiências individuais de alfabetização à luz das teorias do projeto "Toda Força ao $1^{\circ}$ Ano do Ciclo I" e não foi isso que aconteceu. Ao perceber que não haveria espaço para reflexão e nem para 'troca de experiências', as professoras avaliaram que esse curso 'não serviu' para seus anseios enquanto profissionais em exercício.

Consideramos que esse percurso evidencia as possibilidades de desenvolvimento profissional de Estela e Isabela porque elas enxergaram as falhas do curso em relação às suas necessidades de formação. Partindo desse contexto, concordamos com Almeida (2006, p. 4) quando coloca que

contextualizar a formação no âmbito do processo de desenvolvimento profissional dos professores decorre do entendimento de que a formação contínua se processa como algo dinâmico, que vai além dos componentes técnicos e operativos normalmente impostos aos professores pelas autoridades competentes, que não levam em conta a dimensão coletiva do trabalho docente e as situações reais enfrentadas por esses profissionais em suas práticas cotidianas. Essa contextualização também propicia um caráter mais orgânico às várias etapas formativas vividas pelo professorado, assegurando-lhes um caráter contínuo e progressivo. 
Continuemos agora a conversa sobre formação contínua, tendo em vista as outras experiências formativas das professoras em questão. Margareth, comentando sobre os cursos que fez ao longo da carreira diz que ela fez mais curso no Estado e não fez nenhum, além do TOF, na prefeitura por conta da falta de tempo em participar dos cursos oferecidos. Já Estela, participou de tudo quanto pode. Ela nos conta que quando começou a trabalhar com o programa das Classes de Aceleração no Estado, pode participar de muitos cursos:

foi uma época maravilhosa porque eu tive curso com a Telma Weiz. Uma semana junto com a Telma Weiz e com vários outros pedagogos também. Foi lá que eu conheci Paulo Freire, Luckesi, Terezinha Rios, etc, então foi uma época ótima. Em 1998 eu 'conheci' Paulo Freire na Oficina Pedagógica.Nunca tinha ouvido falar de Paulo Freire. Foi na Oficina Pedagógica, em 98, que eu soube da história do 'tijolo', de alfabetizar com a palavra tijolo e que eu fui ler À sombra da mangueira, e que eu li Pedagogia da Indignação, Pedagogia da Autonomia e não sei quantas frases de Paulo Freire. Em 98 eu li Paulo Freire a primeira vez.

Acabamos de ver a importância atribuída por Estela aos cursos que realizou quando participou do programa das Classes de Aceleração. Esse programa precisou oferecer formação diferenciada para os professores formadores porque estes, por sua vez, lidariam diretamente com os professores e os dilemas das salas de aula de crianças que apresentavam defasagem idade-série. Estela, ao demonstrar seu entusiasmo e satisfação diante desses cursos, nos remete à Paulo Freire (1996b, p. 92): o professor que não leve a sério sua formação, que não estude, que não se esforce para estar à altura de sua tarefa não tem força moral para coordenar as atividades de sua classe.

Acreditamos que está suficientemente explícita a importância da formação contínua do professor para que este repense sua prática a fim de melhorar sua atuação profissional. Nessa direção,

a reflexão sobre a prática institui-se a partir de uma necessidade de tornar a prática cotidiana que se dá na escola mais reflexiva e compreendida em seu contexto e se constitui uma forma definidora da identidade do professor $e$ de seu desenvolvimento profissional (GHEDIN, 2006, p. 30).

A professora Estela, refletindo sobre suas experiências de formação contínua, coloca que ela mudou sua prática na sala de aula por conta do estudo mesmo. Ela nos relata os motivos que a levaram a fazer a graduação em matemática.

Fui fazer matemática, mas não amo matemática. Fui fazer justamente por trabalhar na Aceleração e por perceber que as crianças tinham 
muito ódio ou medo de matemática. Então, eu falei 'eu quero saber o que é que acontece'. Então fui fazer curso de matemática. Eu não tinha muitas dificuldades em matemática e não entendia porque as crianças tinham tanto medo. A faculdade foi bastante interessante, mas não me ajudou a solucionar isso. Eu só fui aprender mesmo lendo Wallon, que fala do sentimento, das emoções. A faculdade me ensinou muita coisa de matemática, mas não me ajudou a saber porque a criança tem medo de matemática ou tem tanta dificuldade na matemática. Eu só fui aprender mesmo com esses autores que a gente acha arcaico, que escreveram e que nunca freqüentaram uma sala de aula, que não-sei-o-quê, mas é lendo que a gente reflete, analisa e avalia o problema de cada aluno.

De acordo com o relato de Estela, entendemos que a graduação em matemática adquire, no contexto do seu desenvolvimento profissional, o caráter de uma experiência de formação contínua e não de formação inicial, uma vez que ele ajudou-a a se manter como professora das séries iniciais no Ensino Fundamental. Esse nosso entendimento é coerente com o expresso por Fusari \& Franco (2006, p. 21):

via de regra, a formação contínua vem sendo compreendida como aquela que ocorre após a formação inicial (magistério em nível superior, licenciatura, bacharelado), a partir do ingresso do sujeito na carreira do magistério. Dito de outra forma, tudo aquilo que ocorreu antes do ingresso no trabalho entra na categoria da formação inicial e o que ocorre depois, na categoria de formação contínua. Seria como se tivéssemos dois tempos distintos no processo de formação: um tempo anterior e outro posterior (FUSARI \& FRANCO, 2006, p. 21).

Além disso, a necessidade em fazer o curso de matemática surgiu da constatação da dificuldade dos alunos com essa disciplina. Estela mobilizou seus interesses de formação de acordo com as necessidades surgidas no dia-a-dia da sala de aula. Isso é um indício do seu desenvolvimento profissional. Nesse sentido, Bolívar (2002, p. 117), utilizando as palavras de Canário, afirma que

a formação do professorado é, então, um processo de desenvolvimento pessoal, em relação de continuidade com seus sucessos e experiências anteriores, e não de ruptura, que permitam uma apropriação crítica para as novas situações. Em termos de formação, as conseqüências são claras: o processo formativo adquire os contornos de um processo de desenvolvimento individual, de construção da pessoa do professor, não mediante uma ruptura com as práticas e os acontecimentos passados, mas justamente a partir de uma apropriação crítica desse passado e dessa experiência. A formação se torna, em grande medida, um processo de autoconhecimento.

A formação não se revela na ruptura com as posturas anteriores a ela e sim na continuidade dessas posturas refletidas e transformadas a serviço de uma melhor 
atuação em sala de aula. As experiências passadas orientam o percurso de formação do professor, no caso de Estela, a dificuldade de seus alunos em lidar com a matemática levou-a a querer saber por que isso ocorre e qual o melhor modo de se trabalhar essa dificuldade. Muitas vezes, a solução não é encontrada num curso, numa faculdade ou num livro, mas sim no conjunto de experiências formativas.

Estela se emociona ao relembrar um curso que fez na Editora Moderna através de convênio com a prefeitura de São Paulo:

nós ficamos uma semana na Editora Moderna, ouvindo Ziraldo, Ruth Rocha, Eva Furnari contarem a história deles. Tatiana Belinky, Ana Maria Machado, Cláudio Manuel, Liliane Iacocca, essas pessoas a gente viu pessoalmente e foi muito significativo porque quando você descobre o autor, você descobre como ele escreveu e porque que ele escreve. Descobre também que ele é uma pessoa, um indivíduo que tem um monte de outras dificuldades. O Ziraldo, por exemplo, pra ele mandar um e-mail ele precisava da ajuda do filho, da filha, de todo mundo. Quer dizer, ele tem limitações também. É um grande gênio e tem limitações. Tem algumas coisas, algumas habilidades que ele não consegue.

O relato acima ajuda a confirmar a importância da leitura para a formação contínua do professor de qualquer área. Não podemos nos esquecer de que Estela teve a oportunidade de participar de vários cursos de formação oferecidos tanto pela Rede Estadual, quanto pela Rede Municipal de Ensino. Ela, ao participar do programa Classes de Aceleração, passou por uma formação específica e ao assumir o posto de Assistente Técnico Pedagógico de Aceleração na Oficina Pedagógica, teve outras experiências formativas porque ela mesma se tornara formadora de professores. Quando esta professora assumiu a função de Professora Orientadora de Sala de Leitura na Escola Municipal, ela também fez vários cursos oferecidos especificamente para esses professores. Os relatos de Estela evidenciam o papel que essas diversas formações tiverem em seu processo de desenvolvimento pessoal e profissional.

Quanto a Isabela, apesar do pouco tempo de docência, ela também já participou de cursos de formação contínua oferecidos pela Rede Municipal de Ensino de São Paulo:

Eu tive sorte de começar a carreira no último ano da gestão da prefeita Marta Suplicy do PT. 2004 foi um ano em que apareceram muitos cursos na rede para os professores fazerem. Teve um curso excelente, formulado pela Thelma Weiz, que é especialista em alfabetização, que chamava PROFA - Programa de Formação de Professores Alfabetizadores. Eu consegui fazer o curso à noite. Nesse curso o professor aprende a entender como é que se dá a aquisição da escrita e 
da leitura pela criança. Esse curso mudou muito a minha visão sobre alfabetização, sobre como preparar as atividades desafiadoras para cada nível de hipótese de escrita. Porque você não pode falar assim "ah, o aluno não sabe nada". Ele sabe muito, mesmo o aluno que você pede para escrever, por exemplo 'gato', e ele coloca quinze letras e fala que ali ta escrito 'gato', ele já sabe que se usam letras para escrever. Tem aluno, que no começo da alfabetização, você pede para escrever gato, ele desenha um gato, acha que ali está escrito gato, então a gente chama de garatuja, ele usa desenhos e outros símbolos sem ser letra. Eu passei a ver que todos os alunos sabem alguma coisa e que o nosso desafio é propor atividades para que eles dêem um passo além do que eles já sabem.

Essa formação advinda do curso do PROFA, para além de discutir a questão da alfabetização, ajudou essa professora a saber que os alunos, mesmo os não alfabetizados já trazem um repertório de conhecimentos que precisa ser valorizado pela escola e pode servir como ponto de partida para o trabalho do professor. Quando Isabela fala que os alunos sabem alguma coisa e que o seu trabalho como professora é propor atividades para que eles dêem um passo além do que já sabem, ela se refere implicitamente ao conceito de zona de desenvolvimento proximal de Vygostky. Nessa direção, a formação permanente consiste na prática de analisar a prática. Pensando sua prática, é possível perceber imbuída na prática uma teoria ainda não percebida, pouco percebida ou percebida, mas pouco assumida (FREIRE, 1996, p. 91). Isabela utiliza o conceito criado por Vygostky em sua reflexão sobre a prática pedagógica. Talvez nem tenha se dado conta de que essa teoria embasa sua prática, mas ela está presente em seu relato. Diante disso, concordamos com Becker (2003, p. 71) quando este diz que o professor 'professa' uma epistemologia mais inconsciente do que consciente.

Isabela segue adiante em suas recordações sobre a formação que obteve a partir do ingresso na carreira e confirma a importância da formação contínua para o trabalho do professor:

O professor precisa ter a formação inicial antes de começar na carreira, mas o mais importante é a formação contínua. Não é pra reciclar, pra capacitar porque essas palavras são até meio infames: capacitar? $O$ professor não é capaz de fazer as coisas? Reciclar?O professor não é lixo pra ser reciclado. É o que a gente chama também de formação em serviço, cursos que vão fazer o professor pensar de outra forma, refletir de outra forma, desequilibrar, pelo menos, o que ele pensa porque quando o professor faz um curso e fala 'ah, mas eu não sei como é que eu vou aplicar isso na sala de aula', ele já ta em conflito. É necessário que haja formação em serviço porque foi essa formação que abriu o meu 
horizonte sobre a alfabetização e que mudou a minha prática de alfabetização.

Diante do exposto por Isabela, podemos entender que

uma formação contínua em serviço busca integrar as condições do professor, de seu desenvolvimento profissional e pessoal, o que inclui seus sonhos, aspirações, desejos, valores, ideais, a sua vida, uma formação comprometida com a emancipação humana $e \quad o$ desenvolvimento profissional do professor e das equipes (SOUZA, 2005, p. 48).

A capacidade de avaliar seu desempenho como professora a partir da formação que teve sobre alfabetização demonstra que, em apenas três anos de docência, essa professora avançou no seu processo de desenvolvimento profissional. Isabela coloca ainda que no momento do seu ingresso na carreira em 2004 fez quatro cursos que foram oferecidos a todos os professores da Rede Municipal de Ensino. Porém,como esses cursos não davam direito à dispensa de ponto, precisavam ser feitos fora do horário de trabalho do professor:

Eu fiz, em 2004, quatro cursos. Inclusive cursos que eram de sábado e domingo. E eram cursos cheios, tinha muita gente interessada. Os cursos eram excelentes, os formadores eram muito qualificados, o material era excelente. Um dos cursos que fiz foi Vivências Culturais para Educadores. Foi um curso excelente porque nós tínhamos contato com diversas formas de arte e de expressão artística: teatro, cinema, filmes de qualidade que fazem você refletir sobre determinadas questões da vida humana, da condição humana; artes plásticas, oficina de circo. Tudo isso contribuiu para o professor ampliar seus horizontes e pensar como ele pode modificar a aula dele e trazer essas linguagens para dentro da aula. Você fala assim: ah, mas o que é que eu vou ensinar de circo para eles? Habilidade, coordenação, concentração nos movimentos. Depois de cada oficina havia debates com especialistas em cada formação. Eram palestras que acrescentavam muito pra você mudar o seu olhar. Muitas vezes, muitos professores falavam assim: mas como é que eu vou levar isso pra sala de aula? Mas você precisa primeiro mudar o seu olhar, pra poder você desequilibrar o que você já sabe fazer. Então o primeiro passo para o professor mudar é ele desequilibrar o que ele já sabe.

O desenvolvimento profissional também acontece, em grande medida, a partir do interesse e da disponibilidade do próprio professor. Apesar das iniciativas governamentais frente à questão da formação contínua, se o professor não quiser ou não puder participar dessa formação, a intenção do governo fica comprometida. Nessa direção, Almeida (2006, p. 14), se colocando também no lugar de professora, diz que 
o exercício da docência não pode se resumir à obrigação de darmos vida ao que outros (mesmo que sejam especialistas) elaboram para sustentar o que fazemos. É preciso que tomemos em nossas mãos as decisões que embasam os encaminhamentos de nossas ações.

Para além das iniciativas de formação contínua por parte das Secretarias de Educação, as professoras Margareth, Estela e Isabela contam ainda com um espaço de formação dentro de suas jornadas de trabalho. Como já foi dito antes, os professores da prefeitura podem optar pela jornada de trabalho que querem seguir. Margareth e Estela optaram em 2005, para seguir em 2006, pela Jornada Especial Ampliada. A JEA é composta por 25 horas aula com alunos e 5 horas para formação, sendo que 3 dessas horas deverão ser cumpridas na escola e duas são de livre escolha do professor. Isabela optou em 2005, para seguir em 2006, pela Jornada Especial Integral. A JEI é composta por 25 horas aula com alunos e 15 horas aula para formação, sendo que 8 dessas horas são para o horário coletivo, 3 são individuais e devem ser cumpridas na escola e o restante para livre escolha do professor. Durante o horário coletivo da JEA ou da JEI, o coordenador pedagógico da escola, a partir de diretrizes escolhidas pelo conjunto dos professores e/ou pela própria Secretaria Municipal de Educação, elabora um roteiro de estudos a ser seguido. Esse roteiro pode apresentar momentos para troca de experiências, leituras, reflexões, construção e avaliação de projetos especiais da escola, resoluções de problemas, entre outros.

Esse horário coletivo de trabalho que acontece na própria escola dentro da jornada do professor nos ajuda a corroborar que

nela também nós, professores, aprendemos especialmente sobre a nossa profissão, sobre como ensinar aos nossos alunos. É nela que avançamos nos modos de produzirmos nossa ação, que vamos mudando nossas práticas. E assim a escola também se modifica, se transforma (ALMEIDA, 2006, p. 15).

O desenvolvimento profissional do professor acontece, principalmente, dentro da escola: nas aulas e nos momentos de formação contínua. Almeida (2006, p. 16), confirmando essa iniciativa de alguns governos em oferecer ao professor espaço dentro de sua jornada de trabalho para formação contínua diz ainda que

em um grande número das escolas brasileiras, os professores têm hoje o horário coletivo de trabalho pedagógico, dedicado à discussão, à reflexão e à avaliação do que realizam individualmente, ou em grupos articulados em torno de projetos mais amplos. Nesses momentos de convivência, por meio de estudos e trocas é que produzimos respostas aos problemas presentes no processo de ensino-aprendizagem e também 
nos desenvolvemos, ao mesmo tempo em que a escola também vai se modificando.

O professor se desenvolve profissionalmente e a escola se desenvolve institucionalmente. Sobre essa questão da formação dentro do próprio ambiente de trabalho do professor, Guimarães (2006, p. 42) ressalta que

é preciso, contudo, destacar momentos ou maneiras menos formais, mas que são de grande importância no processo de formação continuada do professor. Trata-se das conversas que os professores entabulam, envolvendo as dificuldades no trabalho e formas de atuar; as maneiras como as coordenações pedagógicas abordam com os professores as questões vindas da sala de aula, contribuindo para a reflexão, para que aprendam a duvidar das aparências dos "problemas de sala de aula" $e$ a desenvolver um diálogo mais crítico com a realidade. São processos menos formais de apoio pedagógico, de "trocas de experiências".

Sobre as 'trocas de experiência', o mesmo autor coloca que

As trocas de experiências são meios interessantes de formação continuada, além de contemplar muito o modo como os saberes profissionais do professor são construídos. [...]. As discussões ou trocas de experiências podem favorecer a releitura da experiência. As perguntas dos colegas, os pedidos de esclarecimentos, as explicações do "porque" se agiu desta ou daquela maneira, são ótimas possibilidades para a reflexão. A contraposição entre o que se fez, a teoria existente e a norma estabelecida pode se constituir em um saudável conflito cognitivo que propicia a releitura e a reinvenção da prática. É por essa via, basicamente, que os professores constroem e se apropriam de saberes profissionais, desenvolvem maior segurança e autonomia na sua atuação.

Tanto Margareth, quanto Estela e Isabela comentam ao longo de suas entrevistas sobre a riqueza das trocas de experiências e ressaltam a importância do horário coletivo como espaço privilegiado para essas trocas acontecerem. Esse conhecimento que é trocado no horário coletivo nos remete aos estudos de Tardif sobre os saberes experienciais - aqueles que vêm através da experiência. Este autor diz que se pode chamar de saberes experienciais

o conjunto de saberes atualizados, adquiridos e necessários no âmbito da prática da profissão docente e que não provêm das instituições de formação nem dos currículos. Estes saberes não se encontram sistematizados em doutrinas ou teorias. São saberes práticos (e não da prática: eles não se superpõem à prática para melhor conhecê-la, mas se integram a ela e dela são partes constituintes enquanto prática docente) e formam um conjunto de representações a partir das quais os professores interpretam, compreendem e orientam sua profissão e sua 
prática cotidiana em todas as suas dimensões. Eles constituem, por assim dizer, a cultura docente em ação (TARDIF, 2005, p. 48-49).

A partir dos relatos fornecidos pelas professoras sobre suas experiências de formação contínua podemos perceber que essa formação está diretamente articulada com seu desenvolvimento profissional. Acreditamos que isso ocorre quando a formação propicia o desenvolvimento dos modos de atuação prática dos professores, o que torna formação e desenvolvimento profissional processos concomitantes e articulados.

\subsection{Autonomia}

A terceira e última categoria de análise que visa à compreensão do desenvolvimento profissional de professores diz respeito à autonomia. E vamos aqui aprofundar seu entendimento como chave para compreensão de um problema específico do trabalho educativo (CONTRERAS, 2002, p. 89). Para tanto, adotaremos o princípio da relação como ponto de entendimento da autonomia docente porque concordamos com Rios (2001, p. 123-124) quando diz que a autonomia é sempre relativa, ou seja, ela é algo que se experimenta em relação, no convívio com outras pessoas. Contreras (2002, p. 199) também participa dessa idéia e reafirma que a autonomia se desenvolve em um contexto de relações, não isoladamente.

Diante do exposto acima, não é possível entender a autonomia de professores sem fazer referência ao(s) contexto(s) de trabalho destes. Antes de elucidarmos esse(s) contexto(s), temos que ter em mente que o ensino, enquanto prática social, não é definido ex novo pelos docentes, mas estes se incorporam a uma instituição, a qual já responde a certas pretensões, uma história, rotinas e estilos estabelecidos (CONTRERAS, 2002, p. 149). Cada rede de ensino, cada instituição, cada escola apresenta um contexto específico de trabalho. Como exemplo podemos citar que a Rede Municipal de Ensino de São Paulo oferece plano de carreira e melhores condições salariais para os professores ao passo que a Rede Estadual de Ensino de São Paulo não o faz na mesma proporção. Os alunos da Rede Municipal têm, em sua grade horária semanal, aulas de Sala de Leitura e de Laboratório de Informática Educativa com professor específico. Igualmente não encontramos tal iniciativa na Rede Estadual. Frente a essas diferenças, encontramos subsídios em Contreras que nos ajudam a compreender a importância do contexto de trabalho dos professores. Para esse autor

a instituição educativa representa um espaço sobre o qual se projetam, de forma contraditória e conflituosa, diferentes pretensões e aspirações, 
tanto culturais como econômicas e sociais. $O$ trabalho do professor não pode, portanto, ser compreendido à margem das condições sociopolíticas que dão credibilidade à própria instituição escolar (CONTRERAS, Ibid; p. 69).

Ao reconhecermos que é somente a partir do contexto de trabalho do professor que se pode compreender a autonomia docente porque é na relação com o contexto de trabalho que o professor exerce e/ou constrói essa autonomia, nos defrontamos com outra importante questão: como compreender a autonomia docente das professoras Margareth, Estela e Isabela, sendo que estas trabalham, ou trabalharam, em diferentes contextos educativos ao mesmo tempo. Vejamos então como as professoras lidam com essa questão.

Margareth, por não ser efetiva na Rede Estadual, fala da falta de possibilidade de autonomia: como eventual você não tem a liberdade de você preparar uma aula. Você tem que fazer exatamente aquilo que o professor titular da sala quer. A menos que você consiga um período grande de substituição. Ela conta ainda que no começo da carreira, quando se tem pouca pontuação para a atribuição de aulas era ainda pior: no início eu não conseguia pegar uma turma só minha. E quando eu substituía, eu seguia ali, contrariada. Ela nos revela um outro dado lamentável da situação do professor eventual frente ao professor titular, na relação de autonomia de trabalho na sala de aula:

Pra não arrumar brigas entre os próprios colegas professores, o meu trabalho era podado. As crianças gostavam mais de uma aula produtiva, como eu tentava trabalhar. Quando eu substituía um dia, uma turma, no outro dia chegava a professora dessa turma e se revoltava porque aqueles alunos estavam achando o máximo a aula do dia anterior e não estavam se interessando pela aula dela. Então o professor titular da sala podava, cortava o meu trabalho.

A situação descrita por Margareth mostra que ela tinha que seguir à risca o que a professora titular da sala trabalhava e que não podia sair fora daquele esquema. Se houvesse alguma coisa diferente, seja para melhor ou para pior, do que a professora titular costumava trabalhar, havia reclamação. Margareth tinha sua possibilidade de autonomia cerceada frente aos modos de ser do professor titular da sala. Partindo desse contexto, lembramos que

a perspectiva do docente como profissional reflexivo nos permite construir a noção de autonomia como um exercício, como forma de intervenção nos contextos concretos da prática onde as decisões são produto de consideração da complexidade, ambigüidade $e$ 
conflituosidade das situações. Essa consciência da complexidade e do conflito de interesses e valores é que faz com que as decisões autônomas tenham de ser entendidas como um exercício crítico de deliberação levando em conta diferentes pontos de vista. Já não falamos da autonomia como uma capacidade ou atributo que se possui, mas de uma construção permanente em uma prática de relações (CONTRERAS, 2002, p. 197).

Sendo a autonomia um exercício inerente a uma prática de relações, entendemos, segundo o relato de Margareth, que a situação do professor eventual não lhes permite exercer essa autonomia plenamente. E isso pode ser mais uma vez visualizado no seu relato transcrito abaixo:

Se você passa por uma substituição de trinta dias, de quatro meses, aí você já vai ter que se adequar ao trabalho do professor. Embora você não mude seu ritmo de trabalho, você busca se adequar ao que o professor da sala costuma fazer. Há professores que têm a capacidade de deixar canetas nas cores exatas que ele usa no preenchimento do seu diário. Então se ele for se ausentar por um período de trinta dias, esse professor deixa as quatro canetas que ele usa que é pra você usar exatamente, somente aquelas canetas no diário dele. Então é complicado.

O professor eventual, que não consegue uma substituição de longo prazo, se vê mergulhado em situações que apresentam limites para sua atuação profissional, para sua autonomia profissional. Com bem diria Terezinha Rios (2001, p. 124), a autonomia se experimenta em situação e não há situação sem que haja limites. Uma situação é uma articulação de limites e possibilidades. Articular esses limites e possibilidades é tarefa do professor eventual que exige dele autonomia para refletir o que é e o que não é possível fazer com determinada turma diante de uma substituição. A escolha por dar prosseguimento ao planejamento elaborado por outro professor para que não haja motivos para reclamações requer boa dose de reflexão e autonomia. Com o apoio de Schön (1995), que nos traz a idéia de profissional reflexivo, podemos entender que há situações da prática profissional em que o sujeito não consegue resolver apenas por meio de repertório técnico. Ao acionar esse repertório técnico, o profissional reflete e articula futuras ações. E é nesse contexto, onde a reflexão se articula com os limites e possibilidades da situação concreta, que a autonomia vai se delimitando.

Margareth diz ainda que com o passar do tempo o professor já tem um conhecimento e sabe que pode usar ou não a sua autonomia, os seus conhecimentos, a sua bagagem. Mesmo sendo professora eventual por muitos anos, essa professora foi 
construindo, ao longo de sua trajetória na carreira, repertório de conhecimentos tácitos e técnicos que lhe permite refletir sobre a prática e escolher caminhos de atuação. Dito de outro modo, não é porque ela seguia à risca o que outro professor fazia, que ela não estava desenvolvendo sua autonomia. Ao refletir sobre os limites presentes em sua atuação e nas negativas que enfrentava no exercício de sua autonomia, e na medida em que buscava outras possibilidades de atuação que poderiam ser colocadas em prática, a professora estava de alguma forma aprimorando o desenvolvimento de sua autonomia e de seu modo de ser professora - ou seja, estava se desenvolvendo profissionalmente.

Perguntamos a essa professora se havia momentos em que ela sentia ser mais adequado não lançar mão de sua autonomia. Sua resposta é na direção de que, dependendo do contexto da escola, sentia-se mais confortável se abrisse mão da autonomia, ou seja, achava que era melhor não questionar nada e usar de sua autonomia apenas dentro da sala de aula.

Nesse campo da autonomia são distintos os modos, as atitudes, as compreensões das nossas professoras. Vejamos como Estela se posiciona frente ao terreno das suas decisões:

Eu tenho um planejamento, um plano de ensino e alguns projetos que precisam ser trabalhados. Eu faço esse planejamento de acordo com os PCNs, com as metas da escola e com o projeto pedagógico. Mas eu estou sempre fazendo intervenções, sempre tentando adequar essas atividades pra atender a criança.

Entendemos que ao tomar para si a decisão de buscar adequações que permitam favorecer a compreensão das crianças, a professora está exercitando uma prática autônoma. Contreras diz que isso acontece porque

o professor ou professora tem que inevitavelmente se defrontar com sua própria decisão sobre a prática que realiza, porque ao ser ele ou ela quem pessoalmente se projeta em sua relação com alunos e alunas, tratando de gerar uma influência, deve decidir ou assumir o grau de identificação ou de compromisso com as práticas educativas que desenvolve, seus níveis de transformação da realidade que enfrenta, etc. Esta consciência moral sobre seu trabalho traz emparelhada a autonomia como valor profissional. Apenas a partir da assunção autônoma de seus valores educativos e de sua forma de realizá-los na prática pode-se entender a obrigação moral[...]. Enquanto obrigação moral autônoma, a profissionalidade docente exige dos professores sua consciência e desenvolvimento sobre o sentido do que é desejável educativamente (CONTRERAS, 2002, p. 78). 
Portanto, é necessário que o professor, no exercício de sua autonomia, reflita sobre sua prática a todo momento para conferir se seus objetivos estão sendo alcançados ou se precisam ser revisados. Há alunos que respondem de uma forma a uma atividade proposta, há os que respondem de outra e há os que não respondem. Isso ocorre porque, mesmo que o planejamento tendo sido feito com cuidado e esmero por parte do professor, há condicionantes do dia-a-dia da sala de aula e da realidade de cada aluno que influenciam diretamente o trabalho do professor. Nesse contexto, se o professor não refletir constantemente sobre sua prática, ele pode perder o fio condutor de seu trabalho e ser apenas um reprodutor de práticas pedagógicas tradicionais como passar um texto na lousa, elaborar um questionário para ser respondido com base nesse texto, etc.

Os conflitos e dilemas que surgem no dia-a-dia da sala de aula só podem ser resolvidos a partir da autonomia dos professores. Sobre isso, Contreras (2002, p. 79) coloca que os processos de deliberação moral não são processos algorítmicos de aplicação de regras, e sim de interpretação do que significam os valores e princípios à luz do caso, e o caso à luz dos princípios. Em outras palavras, é no exercício da profissão que se exerce a autonomia. Isso se dá porque não há como estipular um código de regras e condutas aplicáveis a situações previamente conhecidas. O universo de cada aluno ajuda a construir a 'caixa de surpresa' que existe na relação professor-aluno. E essa relação, para alcançar êxito, precisa do exercício da autonomia, tanto de professores como de alunos. Mas, no momento, nos interessa a autonomia docente apenas.

Perguntamos a Estela o que ela faz quando percebe que uma atividade planejada com antecedência não se configura como viável para seus alunos. Ela respondeu:

Procuro por outra atividade que talvez me leve ao mesmo resultado. Que ajude o aluno a atingir os mesmos objetivos, mas de outra forma. Por exemplo, esse ano que eu estou no TOF, tem algumas atividades propostas do livro do TOF que eu não consigo realizar com a sala porque eu não consigo despertar o interesse da turma de alunos. Então, eu simplesmente troco por outra atividade que talvez atinja os mesmos objetivos e que desperte o interesse dos alunos.

Essa professora, ao refletir sobre o interesse da sala por determinada atividade e ao trocá-la por outra que leve aos mesmos objetivos, está exercendo sua prática de modo autônomo, com propriedade e com a percepção a respeito doque 
favorece mais o alcance de seus objetivos educacionais. Isso acontece, segundo Contreras (2002, p. 83) porque para o professor

só é possível realizar juízos e decisões profissionais quando este dispõe de um conhecimento profissional do qual extrair reflexões, idéias e experiências com os que se pode elaborar tais decisões. Isto não implica necessariamente um corpus único e estabelecido de conhecimento avalizado pela pesquisa, nem compartilhado por todos os docentes. Pelo contrário, parece que temos que pensar num conhecimento que é em parte individual, produto das reelaborações sucessivas dos docentes a partir de suas experiências, em parte compartilhado, por obra dos intercâmbios entre professores e processos comuns de socialização, e em parte diversificado, produto de diferentes tradições e posições pedagógicas, o que supõe formas diferentes de interpretar a realidade escolar, a ação docente e as aspirações educativas.

Continuando seu relato sobre a questão da autonomia, Estela coloca que sempre justifica suas ações quando ela escolhe trabalhar com outras atividades que não estão contempladas previamente no planejamento:

Geralmente sou eu mesma que faço por minha conta a troca de atividades. A única coisa que eu faço para atender a coordenação é registrar isso. Eu sou responsável porque acredito que aquela atividade não obteve a resposta esperada na minha sala. Então eu justifico para o coordenador de forma escrita. Eu registro que não vou trabalhar aquela atividade porque não despertou interesse, ou as crianças não foram instigadas o suficiente e por isso eu não consegui realizar tal atividade com minha sala.

Isso evidencia que a autonomia caminha junto com a consciência da responsabilidade profissional. A professora não deixa de fazer uma atividade sem registrar o motivo que a levou a não fazê-la. Contreras (2002, p. 195) refere-se a isso ao colocar que ninguém pode assumir pelo professor o juízo e a decisão diante das situações que requerem uma atuação em sala de aula. Cabe ao professor refletir, experimentar outra atividade e justificar esse experimento.

Quisemos saber de Estela como ela conquista e exerce sua autonomia no dia-a-dia da sala de aula. Ela nos disse que

na verdade a coordenação não me dá autonomia. Eu conquisto meio 'na marra'. Eu digo que não vou fazer tal atividade porque quem está na sala de aula sou eu. Porque eu não vou constranger o meu aluno, não vou forçá-lo a fazer uma atividade maçante, uma coisa que ele não quer fazer ou que ele faça de qualquer jeito só para atender a coordenadora ou a Secretaria. Eu sou uma servidora pública da criança. Eu tenho uma autonomia na sala. E atendo a todos os requisitos da coordenação: não vou fazer, por quê? Aí eu registro. Justifico. E ela não tem como não 
acatar. E é lógico que se vier alguma punição, sou eu que vou responder.

A clareza de sua responsabilidade perante o exercício de sua autonomia está muito clara no relato de Estela, na medida em que ela assume os riscos de uma prática docente coerente com seus princípios, valores e com sua formação. Ela não deixa de atender os requisitos colocados pela escola, pelo sistema de ensino, apenas encontra outras formas de se alcançar os objetivos necessários com os alunos. E ela continua seu depoimento nesse sentido ao comentar o andamento do projeto Toda Força ao $1^{\circ}$ Ano do Ciclo I:

no mês de agosto, a sugestão é trabalhar com contos de fada. Mas a minha criança ainda tem medo de assombração e acredita em saci porque mora num lugar que é mais afastado. Essa criança escuta barulho no meio do mato, porque ele atravessa o mato pra poder ir pra escola, porque ele escuta barulho e sai correndo, porque acha que a loira que é a Clotilde que quer assombrar. Então eu fui trabalhar Câmara Cascudo. Com aqueles contos de mistério. Por que eu tenho que trabalhar com Rapunzel e Branca de Neve que nem condiz com a gente? Essas imposições é que atrasam o nosso trabalho. Então nos dê liberdade, nos oriente. Eu acho que eu tenho que aproveitar essa fantasia da minha criança e partir dali. Com certeza ele gosta muito mais de ouvir $O$ Afilhado do Diabo do que a Rapunzel. As crianças ficaram apaixonadas por Pedro Malasarte, eles estão doidos pra conhecer mais histórias do Pedro Malasarte. Mas eu 'não posso', porque não está no TOF. Não posso teoricamente, porque eu continuo procurando Pedro Malasarte e as outras aventuras dele.

O depoimento de Estela evidencia a importância da autonomia para que se possa produzir respostas adequadas às demandas específicas apresentadas pelos alunos. Nessa direção também se posiciona Contreras (2002, p. 196), quando este diz que o docente se vê obrigado a assumir, por si só, um compromisso pessoal com os casos concretos, a atuar em função de suas próprias interpretações, convicções e capacidades. Entendemos que a posição assumida por Estela evidencia o exercício de autonomia docente.

Acreditamos que esse exercício se torna mais freqüente quando o professor adquire mais experiência e, por conseguinte, encontra-se em estágios mais avançados do seu desenvolvimento profissional. Podemos vislumbrar isso em outra declaração de Estela: em 2001 e 2002 eu já arriscava mais, não tinha medo de arriscar mesmo. Assumir riscos é, também, assumir responsabilidade. A competência profissional é o que capacita o professor para assumir responsabilidades, mas que 
dificilmente pode desenvolver sua competência sem exercitá-la, isto é, se carecer de autonomia profissional (CONTRERAS, 2002, p. 85).

Vejamos agora como a professora, com menor tempo de carreira docente, lida com a autonomia em sala de aula. Isabela comenta uma experiência que teve em seu segundo ano como professora do quarto ano do Ensino Fundamental:

eu tive uma experiência diferente porque nessa quarta série eu fiz sistema de rodízio com uma professora de uma outra quarta série. Eu fiquei com as matérias de Português, História e Geografia e a outra professora com Matemática, Ciências e Artes. Os alunos tinham um professor de Educação Física. Então como que era o rodizio? Metade do período eu ficava com a quarta A e metade do período com a quarta $B$ ensinando Português, História e Geografia e a outra professora ensinando as outras disciplinas.

O sistema de rodízio é uma prática possível na rede pública de ensino de São Paulo. Ele consiste em uma divisão das disciplinas entre duas ou mais professoras. Geralmente o rodízio acontece no terceiro e no quarto ano do Ensino Fundamental. As professoras têm autonomia para decidir se querem ou não fazer o rodízio de disciplinas e a direção da escola dá o aval final. No caso de Isabela, apenas ela e sua colega optaram por compartilhar duas turmas de quarto ano. Essa possibilidade de escolha a respeito dos modo de organizar o trabalho pedagógico nos remete a Chakur (2001, p. 28) quando esta afirma que

ainda restam ao professor certas margens de autonomia no desenvolvimento do seu trabalho, pois o caráter radicalmente indeterminado da prática sempre exigirá a responsabilidade do professor e sua capacidade para definir as situações e o próprio papel que deve ocupar na prática. É, pois, o professor que deve decidir a respeito da forma de interação a ser estabelecida com seus alunos $e$ entre estes, do tipo de atividade a ser realizada e sua seqüência, espaçamento e duração, dos recursos didáticos que mobilizará e das estratégias que podem ser utilizadas e muitas coisas mais.

A possibilidade do rodízio lega ao professor a oportunidade de trabalhar com as disciplinas que lhe são mais familiares e causam mais prazer. É sabido que o professor dos anos iniciais do Ensino Fundamental trabalha com todas as disciplinas e é tido como um professor polivalente. Nem todo professor gosta de todas as disciplinas da mesma forma. Há aquelas com que sobre as quais ele se identifica mais e se sai melhor. O exercício da autonomia permite ao professor elaborar formas alternativas de organização das turmas e das disciplinas desde que encontre um par que demonstre igual disposição de organização. 
Outro aspecto da atuação autônoma de Isabela refere-se ao seu planejamento, uma vez que ela o altera sempre que acha necessário e pertinente. Sobre isso, ela diz que:

eu não consigo dar conta de todo o conteúdo que está no planejamento porque eu trago muita coisa de fora dele ao longo do ano. Quando eu vejo uma propaganda na televisão e percebo que é importante comentála com meus alunos, acrescento essa reflexão no meu planejamento. Eu trago leituras diversas que vou encontrando ao longo do ano e proponho uma produção de texto para os alunos analisarem alguma questão. Assim, eu não consigo nunca cumprir todo o conteúdo que está no planejamento porque há alterações significativas neste.

A alteração no planejamento oriundo da consciência de que outras atividades são necessárias para o desenvolvimento daqueles alunos só pode acontecer mediante o exercício da reflexão. Nesse sentido,

a perspectiva do docente como profissional reflexivo nos permite construir a noção de autonomia como um exercício, como forma de intervenção nos contextos concretos da prática onde as decisões são produto de consideração da complexidade, ambigüidade $e$ conflituosidade das situações. Essa consciência da complexidade e do conflito de interesses e valores é que faz com que as decisões autônomas tenham de ser entendidas como um exercício crítico de deliberação levando em conta diferentes pontos de vista. Já não falamos da autonomia como uma capacidade ou atributo que se possui, mas de uma construção permanente em uma prática de relações (CONTRERAS, 2002, p. 197).

Quando pedimos que Isabela nos desse detalhes sobre sua autonomia docente, ela nos contou o seguinte:

A autonomia na sala de aula é assim: eu faço o que acho que os alunos estão precisando. Se o planejamento prevê em matemática, agora na segunda série, que é para ser trabalhada a divisão e os meus alunos ainda não se apropriaram direito de adição e subtração com reserva e com recurso, eu não vou partir pra divisão, mesmo que esteja lá no planejamento da segunda série de que agora em junho tem que aprender divisão. Não vou. Eu tenho essa autonomia.

$O$ ano passado, na primeira serie, nós tínhamos que trabalhar o projeto do 'Gato Malhado e da Andorinha Sinhá' em várias etapas. Uma das etapas era para trabalhar com soneto, só que na minha sala de primeira série não dava para eu trabalhar o que era o soneto porque eles ainda estavam se alfabetizando. Então teve gente que trabalhou vinte dias, todo dia passava uma das atividades previstas no projeto, aí o aluno não agüentava mais ouvir falar no Gato Malhado e na Andorinha Sinhá. Na minha sala eu trabalhei três dias com a ficha técnica do animal porque eu achei suficiente e apropriado para o que eu já estava trabalhando que era a alfabetização. 
O professor, a partir do contexto de sua turma de alunos, analisa seu trabalho e avalia o que precisa ser alterado no planejamento para que seus alunos construam uma relação positiva com o conhecimento. Isabela nos mostra que o importante é levar em consideração o que seus alunos já sabem e partir daí para que eles possam vir a saber mais. Sem o exercício da autonomia, o professor não consegue articular suas reflexões sobre o que considera melhor para seus alunos em relação aos objetivos pretendidos com determinada turma. A experiência no magistério permite ao professor dispor de conhecimentos que o auxiliam no momento de avaliar o desenvolvimento de sua turma de alunos e de propor atividades que melhorem esse desenvolvimento. Isso tudo implica no exercício da autonomia que surge num processo reflexivo.

Isabela, assim como a professora Estela, afirma a importância de se justificar e registrar o desenvolvimento dos alunos e as alterações que se faz no planejamento da classe:

Eu registro e explico. Tem também os relatórios que a gente faz principalmente dos alunos que não estão acompanhando. Eu escrevo o porquê daquela atividade ter sido trocada, porque não fez a divisão ainda... E há autonomia sim. Tem professor que segue o planejamento como se fosse a Bíblia. Mas eu não. Eu sigo de acordo com o que meus alunos estão precisando aprender, de acordo com o que eu sinto com a sala. Tem sala que você pode andar mais, tem sala que você anda menos. Tem que ser no ritmo deles, mas sempre puxando pra aprender.

Frente ao exposto acima, entendemos que

A autonomia é necessária como requisito de qualidade profissional, tanto em termos de reivindicação trabalhista, como de exigência educativa. No entanto, os professores, muitas vezes condicionados a realizar prescrições externas, podem perder o sentido do trabalho que desenvolvem, bem como as capacidades que permitem a visão de conjunto e a aptidão para decidir (PAPI, 2005, p. 43).

$\mathrm{Na}$ oposição frontal ao fortalecimento da autonomia dos professores estão as prescrições externas, que podem vir sob a forma de projetos ou programas criados sem a participação deles como, por exemplo, o projeto Toda Força ao $1^{\circ}$ Ano do Ciclo I - TOF. Ou, no caso específico colocado pela professora Isabela, o projeto da escola intitulado "O Gato Malhado e A Andorinha Sinhá”. Esses projetos estabelecem objetivos a serem alcançados que, na maioria das vezes, não leva em consideração as especificidades de cada escola e de cada sala de aula. Por isso, os professores precisam 
estar atentos à forma como vão articular seu trabalho pedagógico com esses projetos. Eles não podem se deixar condicionarem pelas prescrições externas porque a prática pedagógica conseqüente requer capacidade para decidir o que é melhor para sua turma de alunos. Requer o exercício da autonomia.

Com o apoio de Contreras e dos relatos das professoras Margareth, Estela e Isabela, consideramos que a autonomia, no contexto da prática do ensino, deve ser entendida como um processo de construção permanente no qual devem se conjugar, se equilibrar e fazer sentido muitos elementos. Por isso, pode ser descrita e justificada, mas não reduzida a uma definição auto-explicativa (CONTRERAS, 2002, p. 193). Sendo a autonomia um processo de construção permanente, que envolve a tomada de posição frente a cada situação prática, entendemos que ela se constitui em elemento essencial do processo de desenvolvimento profissional de professores, que está sempre em constante modificação ao longo de toda a carreira docente.

As informações contidas nos relatos das três professoras evidenciam que o conjunto das experiências vivenciadas no percurso da carreira mostra o quanto é importante a capacidade de se refletir sobre a prática e de tomar decisões que se julgue importante para o trabalho com os alunos. Essa reflexão e essa tomada de decisões exigem autonomia por parte do professor. Nessa direção,

a autonomia, como os valores morais em geral, não é uma capacidade individual, não é um estado ou um atributo das pessoas, mas um exercício, uma qualidade da vida que vivem. Teremos de falar, portanto, de processos e situações sociais nas quais as pessoas se conduzem autonomamente. A autonomia é, então, como diria Thiebaut (1988), uma qualidade circunstancial (CONTRERAS, 2002, p. 197).

É a circunstância que vai exigir do professor que este utilize seu repertório de saberes e que coloque em prática ou não sua autonomia. Day (1999, p. 31), ao relacionar a autonomia de professores com seu desenvolvimento profissional, diz que os professores estão a reafirmar a sua autonomia a par das novas responsabilidades que lhes são exigidas e a interpretar ativamente a reestruturação do seu trabalho em conformidade com os seus próprios juízos profissionais. Entendemos que esses 'juízos profissionais' sofrem influência e podem ser reelaborados a partir de cada experiência vivida pelo professor nas diversas situações escolares. Desse modo é que enxergamos a relação entre autonomia e desenvolvimento profissional. 
De acordo com o que discutimos até aqui, a escola ciclada colocou ao professor novas demandas para o ensino, como, por exemplo, diferentes formas de organização do tempo e do espaço escolar, flexibilização do currículo adequada à realidade de cada comunidade, necessidade de desenvolver outros modos de motivar o aluno, o que requer mudanças na relação com o conhecimento.

Nesse novo cenário o processo de ensino e aprendizagem precisa ser pensado para além das fronteiras do ano letivo. Isso exige do professor um outro olhar para a questão do trabalho com o conhecimento. Esse olhar, segundo as professoras Margareth e Estela, apontou para a indissociabilidade entre ensinar e aprender. Uma ação não existe sem a outra. O conhecimento é compartilhado entre professores e alunos e está em constante movimento e reelaboração.

O pressuposto da escola seriada é que o currículo seja organizado de modo que o professor possa dar conta dos conteúdos estabelecidos para cada ano letivo, sem se preocupar em encontrar caminhos pedagógicos alternativos para os alunos que apresentam baixo rendimento escolar. Ensinar é então função do professor e aprender éfunção do aluno. A proposta da escola ciclada parte de outros pressupostos, na medida em que se propõe a incluir os alunos que têm algum tipo de dificuldade de aprendizagem desde a fase de elaboração de seu planejamento. Ensinar e aprender passam a fazer parte de um processo único. Nessa direção, entendemos, de acordo com o relato das professoras que também vivenciaram a experiência da escola seriada Margareth e Estela, que a indissociabilidade entre ensinar e aprender ganhou força a partir da organização do ensino em ciclos. Os ciclos estabeleceram necessidades diferentes para o trabalho com o conhecimento na escola e o professor passou a ser o principal responsável por lidar com essas necessidades. Isso nos leva a pensar que essa mudança de paradigma do processo de ensino e aprendizagem foi percebida e apropriada pelas duas professoras em questão, o que nos permite dizer que seus modos de serem professoras foram se transformando e instituindo novas facetas aos seus processos de desenvolvimento profissional. A força desse novo paradigma mostra sua importância na medida em que até mesmo a professora Isabela, que não passou pelo regime seriado, também apresenta em seu relato a consciência da indissociabilidade entre ensinar e aprender.

Um outro pressuposto da proposta da escola ciclada diz respeito à necessidade de formação contínua dos professores para que possam reelaborar constantemente sua prática pedagógica de modo a atender as reais necessidades dos 
alunos. Vimos, com os depoimentos das três professoras, que a formação contínua está essencialmente articulada ao desenvolvimento dos seus modos de serem profissionais e que as experiências de formação trouxeram contribuições importantes para a constante reformulação dos seus modos de serem professoras na escola pública contemporânea.

Margareth, Estela e Isabela nos ajudaram a evidenciar a importância da formação contínua, enquanto meio de fortalecimento da atuação profissional e também pessoal, para o exercício da autonomia. Seus depoimentos demonstram que as oportunidades de formação e de desenvolvimento facilitaram a reflexão e a avaliação e a condução das circunstâncias que necessitam de respostas autônomas.

As vivências, as percepções e as experiências das professoras que vivem hoje a possibilidade de atuar na escola pública em transformação e de contribuir para a construção coletiva dos modos de ser professor na atualidade, nos mostram que a formação contínua, os novos modos de relação com o conhecimento no âmbito escolar e o exercício da autonomia fazem parte de uma tessitura intricada, que constitui o terreno fértil onde o desenvolvimento profissional docente se desenvolve. 


\section{CONSIDERAÇ̃̃es FINAIS}


Tendo a profissão docente como tema e o desenvolvimento profissional como objeto de estudo, construímos um trabalho de pesquisa que buscou trazer contribuições a respeito dos modos de ser professor na escola pública contemporânea. Acreditamos que nosso estudo se justifica diante das constatações de que a profissão docente vem passando por transformações profundas, decorrentes das igualmente profundas mudanças sociais presentes na sociedade contemporânea.

Desse modo, as questões que mobilizaram essa investigação foram: o desenvolvimento profissional vivido pelas professoras entrevistadas é fruto de escolhas pessoais ou ele acontece de forma espontânea ou involuntária? As professoras percebem, na medida que avançam na carreira docente, os impactos do seu desenvolvimento profissional nos modos de ensinar? Para lidar com essas questões, definimos a Rede Municipal de Ensino de São Paulo como o lócus da investigação.

Como a categoria profissional dos professores não constitui uma categoria homogênea e nem possui regras e condutas universais, sentimos necessidade de delimitar nossa fonte de pesquisa. Convidamos, então, três professoras que estavam atuando, em 2006, nos anos iniciais do Ensino Fundamental em escolas públicas municipais de São Paulo e que estavam em diferentes fases da carreira. Com isso buscamos obter dados que nos permitissem refletir sobre o desenvolvimento profissional de professores ao longo da carreira docente.

$\mathrm{Na}$ direção que desenhamos acima, definimos um repertório de estudos que contou com discussões sobre a profissão docente, a carreira do magistério e as professoras da Rede Municipal de Ensino. Sobre a profissão docente, desenvolvemos estudos sobre a influência que as transformações sociais legam a essa profissão. Isso acontece porque os sistemas de ensino, por serem parte integrante das sociedades, sofrem influência direta dos seus desenvolvimentos tecnológicos, culturais, econômicos, etc. Simultaneamente ao contexto de transformações sociais e de avanços tecnológicos e científicos, o trabalho do professor assumiu novas demandas como, por exemplo, atuar como psicólogo, assistente social, conselheiro, mãe, pai, etc. Tudo isso visando ao melhor trabalho pedagógico com o aluno em sala de aula.

Nesse caminho, nos defrontamos com a necessidade aprofundar estudos sobre o conceito de carreira docente. Entendemos que a carreira sofre influência da instituição que a abriga. Cada instituição, seja as Secretarias de Educação ou os órgãos descentralizados de gestão do ensino, apresenta normas e condutas diversas e específicas para a configuração da carreira docente sobre sua esfera de atuação. Por 
conta dessa diversidade de normas e condutas, adotamos como referência a carreira instituída pelo Estatuto do Magistério Público Municipal de São Paulo.

Além disso, o pressuposto principal, que nos orienta no entendimento da carreira, consiste em considerar que o professor que transita por diferentes redes de ensino ultrapassa as fronteiras das carreiras instituídas por essas redes e acaba por construir seu próprio trajeto profissional de acordo com suas aspirações. Isso não indica que ele não vá cumprir as normas e condutas existentes nos Estatutos de cada instituição, pelo contrário, indica que ele vai elaborar formas de se posicionar frente a esses Estatutos. Dito de outro modo, o conjunto das experiências vivenciadas pelo professor nas diferentes carreiras das redes de ensino nos leva a formular uma compreensão de carreira que leve em conta tanto a vertente institucional desta quanto a vertente pessoal. A vertente institucional diz respeito ao que está posto nos Estatutos de legitimação da carreira profissional do professor e a vertente pessoal refere-se às possibilidades e às necessidades de vida de cada professor. Não há como entender o desenvolvimento profissional de um professor que circulou por mais de uma rede de ensino delimitando sua carreira a uma única rede. Nessa direção, a carreira como percurso profissional é diferente da carreira estabelecida por um Estatuto, mas ambas ajudam a formar a carreira do magistério vivenciada por cada professor.

Para a compreensão e análise dos depoimentos das professoras entrevistadas adotamos como referencial teórico, os estudos da História Oral e da carreira vista a partir da história de vida. A História Oral nos possibilita compreender a trajetória de um grupo social (os professores) a partir do relato de alguns membros desse grupo (três professoras) porque a experiência individual carrega muito da experiência coletiva e vice-versa. Ao lado da História Oral, buscamos apoio teórico nos estudos sobre a carreira do professor problematizada a partir da história de vida deste. Consideramos a carreira do professor como fonte para a investigação do desenvolvimento profissional docente. Nessa perspectiva, essa pesquisa se insere também no contexto de tomar a carreira docente e as histórias de vida profissional como ponto de partida para o entendimento do desenvolvimento profissional das professoras por nós entrevistadas.

O caminho metodológico - de acordo com os pressupostos da pesquisa qualitativa - que percorremos pautou-se pela utilização de entrevistas semi-estruturadas, realizadas no segundo semestre de 2006, e recorrentes, uma vez que foram retomadas 
no primeiro semestre de 2007. As entrevistas foram transcritas e editadas com preservação do sentido original das falas.

A análise dos percursos vividos pela professoras e por nós recolhidos foi realizada a partir da definição de três categorias: a relação com o conhecimento, a formação contínua e a autonomia. Entendemos que essas categorias configuram-se como elementos chaves para a compreensão do desenvolvimento profissional docente por se constituírem nas bases mesmo desse processo intenso e contínuo vivido ao longo da carreira docente.

Ao tecermos um breve histórico sobre o surgimento da Rede Municipal de Ensino de São Paulo pudemos ter acesso a informações que confirmam seu grande tamanho e suas especificidades. Uma dessas especificidades diz respeito à forma como o Ensino Fundamental está organizado: dois ciclos de quatro anos de duração cada. Vimos que a iniciativa de se experimentar formas alternativas ao regime seriado para conter o fracasso escolar se deu em diversas partes do Brasil. Os ciclos trouxeram novas demandas ao trabalho do professor como, por exemplo, a necessidade de avaliação contínua do desenvolvimento do aluno e a possibilidade de continuação do trabalho pedagógico de um ano letivo para o outro.

Refletindo sobre a questão dos ciclos no contexto da Rede Municipal, notamos que os relatos das professoras Margareth, Estela e Isabela ajudaram a evidenciar que os ciclos ainda não estão consolidados como novo modo de configuração da escolarização fundamental em São Paulo e que ainda há um bom caminho a ser percorrido até que esta forma de organização do ensino alcance o êxito desejado.

No desenvolvimento dos outros dois pilares que dão sustentação ao nosso estudo - profissão docente e desenvolvimento profissional - desenvolvemos uma reflexão sobre a história da profissão de professor em Portugal e no Brasil. Articular a história da docência em Portugal com a história da docência no Brasil se fez pertinente porque o Brasil foi colônia portuguesa por mais de três séculos e, por isso, sofreu influências dos modos como essa profissão se constituía na metrópole. Tendo em vista a história dessa profissão em nosso país, pudemos constatar que a legislação buscou legitimar o ensino oficial e a profissão de professor. Depois de a docência ter sido consolidada como profissão e de a expansão do ensino ter ganho corpo nas propostas do governo, a formação de professores passou a ser uma preocupação dos estudiosos de educação e, também, dos próprios governos. Em meio às propostas oficiais de formação, os professores foram se desenvolvendo profissionalmente, seja através de 
formação institucional - promovida pelos órgãos que administram as redes de ensino ou através de formação realizada por iniciativa pessoal - oriunda do interesse e da necessidade do próprio professor.

Tomamos como base a pessoa do professor, sua trajetória profissional e suas escolhas dentro dessa trajetória como subsídio importante para a reflexão sobre o desenvolvimento profissional. Nessa direção, entendemos o desenvolvimento profissional como um processo que se inicia no momento em que o professor começa a exercer a profissão, e que não tem prazo específico para terminar. Esse processo, que é inerente ao exercício da docência, sofre influência das experiências vivenciadas pelas professoras ao longo de suas trajetórias profissionais. Essas experiências são oriundas de relações estabelecidas com cada sala de aula em que o professor esteve trabalhando, de cursos de formação contínua, de 'trocas de saberes' da prática entre os colegas professores e de reflexões realizadas a partir de tudo isso. Todos esses aspectos constitutivos da docência vão sendo articulados, hierarquizados e selecionados ao longo da carreira na confluência com as condições objetivas de trabalho presentes na rede de ensino e na escola. Acreditamos, então, que o desenvolvimento profissional influencia diretamente os modos de ser dessas professoras.

Como as trajetórias profissionais de Margareth, Estela e Isabela aconteceram em mais de uma rede de ensino, precisamos considerar o caráter individual, subjetivo e pessoal de cada professora em relação à sua formação e, conseqüentemente, ao seu desenvolvimento profissional.

Partimos dos princípios que o conhecimento se configura como a matéria-prima do trabalho do professor e que ele é uma construção social. Nessa direção, Margareth, Estela e Isabela relatam seus modos de se relacionar com o conhecimento ao longo de suas carreiras. Os relatos dessas professoras demonstram que o desenvolvimento profissional também está vinculado à relação que as professoras estabelecem com o conhecimento. Como essa relação se modifica de acordo com as experiências vividas na carreira, o desenvolvimento profissional precisa ser compreendido como um processo contínuo.

Outro aspecto ao qual dedicamos especial atenção é a formação contínua das professoras entrevistadas. Partimos do princípio que a formação contínua influencia diretamente o desenvolvimento profissional do professor e é por ele influenciada. Em outras palavras, não há desenvolvimento sem formação e nem formação sem desenvolvimento. Nessa direção, entendemos, também, que não há como separar os 
itinerários de formação das trajetórias de vida das professoras. Os acontecimentos da vida pessoal e profissional apontam os caminhos para a formação destas.

As professoras, ao longo das entrevistas, refletiram sobre seus modos de ser professora na escola pública contemporânea à luz das influências advindas das experiências de formação contínua. Margareth, Estela e Isabela atribuíram grande importância para a formação contínua oferecida para os professores pelas Redes de Ensino. Essas professoras também acreditam que as experiências de formação contínua vividas por cada uma delas influenciaram diretamente suas práticas de ensino e, por conseqüência, seus desenvolvimentos profissionais.

A autonomia foi a última categoria que nos auxiliou na análise dos dados. Entendemos que a autonomia só existe em exercício porque é a circunstância que vai exigir do professor que este utilize seu repertório de saberes e que coloque em prática ou não sua autonomia. Nesse sentido, a autonomia configura-se como um processo de construção permanente que está diretamente ligada ao desenvolvimento profissional de professores.

Á guisa de conclusão, a relação com o conhecimento, a formação contínua e a autonomia de professor nos forneceram subsídios que nos levaram a entender que o desenvolvimento profissional de professoras da escola pública paulista permitiu que essas professoras seguissem caminhos distintos nas trajetórias de suas carreiras sempre tendo como objetivo principal a melhoria de sua atuação profissional. Frente a isso, visualizamos as percepções de Margareth, Estela e Isabela sobre seus processos de desenvolvimento profissional e as influências destes nos seus modos de ser professora. O que nos levou a identificar que o tempo de carreira no magistério, que abriga a experiência e a vivência profissional, influencia o modo de ser professor. Diante disso, o desenvolvimento profissional vivido pelas professoras participantes da pesquisa é fruto de escolhas pessoais e ele não acontece de forma espontânea ou involuntária.

Os modos de ser professor não são fixos ou imutáveis e se modificam durante a ação do professor no contexto de trabalho deste. As professoras perceberam, à medida que foram avançando na carreira docente, os impactos do seu desenvolvimento profissional nos seus modos de ensinar. Em suma, ao longo dos anos da carreira o professor vai se desenvolvendo profissionalmente, vai refletindo sobre seu modo de ser e de estar na profissão e vai criando e modificando sua ação pedagógica. 
BibLIOGRAFIA 


\section{Legislação Consultada}

Lei $n^{\circ} 11229 / 92$ - Estatuto do Magistério Público Municipal

Lei n 14660/07 - Estatuto dos Profissionais da Educação Municipal

Lei n ${ }^{\circ}$ 9394/96 - Lei de Diretrizes e Bases da Educação Nacional

Lei n ${ }^{\circ}$ 5692/71 - Lei de Diretrizes e Bases da Educação Nacional

Lei n ${ }^{\circ}$ 4024/61 - Lei de Diretrizes e Bases da Educação Nacional

Lei Geral do Ensino de 1827

\section{Referências Bibliográficas}

ALMEIDA, Maria Isabel de. O Sindicato como instância formadora dos professores: novas contribuições ao desenvolvimento profissional. SP: FEUSP, 1999a (Tese de Doutorado).

Os professores diante das mudanças educacionais. In: BICUDO, Maria Aparecida Viggiani \& SILVA JÚNIOR, Celestino Alves (Orgs.). Formação do Educador: organização da escola e do trabalho pedagógico, v. 3. São Paulo: Editora UNESP, 1999 b.

Docentes para uma educação de qualidade: uma questão de desenvolvimento profissional. In: Educar em Revista, Curitiba, n.24, p. 165-176, Editora UFPR, 2004a.

O Trabalho dos Educadores. In: SILVA, Ainda Maria Monteiro; AGUIAR, Márcia Ângela da Silva (org.). Retrato da Escola no Brasil. Brasília: Is.d.I, 2004b, p. 105 à 118.

Formação Contínua de Professores. In: CASTRO, Tânia Maria Magalhães. Formação contínua de professores. Brasília, DF : MEC/SEED/TV ESCOLA, 2006.

ALTET, Marguerite. A especificidade da profissão de professor. In: PAQUAY, Léopold, et. al. Formando professores profissionais: Quais estratégias? Quais competências? Porto Alegre: Artmed, 2001.

BARRETO, Elba Siqueira de Sá e MITRULIS, Eleny. Trajetória e desafios dos ciclos escolares no País. In: Estudos Avançados, São Paulo, v.15, n. 42, p. 103-140, USP/IEA, 2001. 
BECKER, Fernando. A origem do conhecimento e a aprendizagem escolar. Porto Alegre: Artmed, 2003.

BOGDAN, Roberto C. \& BIKLEN, Sari Knopp. Investigação qualitativa em educação: uma introdução à teoria e aos métodos. Porto: Porto Editora, 1994.

BOLÍVAR, Antônio. Profissão Professor: o itinerário profissional e a construção da escola. Bauru: EDUSC, 2002.

BRASIL. SECRETARIA DE ENSINO FUNDAMENTAL. Parâmetros Curriculares Nacionais. Brasília: MEC, 1997.

CAETANO, Ana Paula. Dilema dos professores. In: ESTRELA, Maria Teresa (org.).

Viver e construir a profissão docente. Porto: Porto Editora, 1997.

CAMARGO, Marculino. Filosofia do Conhecimento e Ensino-Aprendizagem. Petrópolis: Vozes, 2004.

CANÁRIO, Rui. ECO: um processo estratégico de mudança. In: D’ESPINEY, R; CANARIO, R. (Orgs.). Uma escola em mudança com a comunidade. Lisboa: Instituto de Inovação Educacional, 1994.

CASTRO, Magali de. A escola normal revisitada: memórias de professoras do início do século XX. In: PEIXOTO, Ana Maria Casasanta \& PASSOS, Mauro (orgs.). A escola e seus atores - educação e profissão docente. Belo Horizonte: Autêntica, 2005, p. 150163.

CHAKUR, Cilene R. de Sá Leite. Desenvolvimento profissional docente: contribuições de uma leitura piagetiana. Araraquara: JM Editora, 2001.

CHARLIER, Évelyne. Formar professores profissionais para uma formação contínua articulada à prática. In: PAQUAY, L. et al. Formando professores profissionais: Quais estratégias? Quais competências? Porto Alegre: Artmed, 2001.

CATANI, Denice Bárbara (Org.). Docência, Memória e Gênero: estudos sobre formação. SP: Escrituras Editora,1997.

CAVACO, Maria Helena. Ofício do professor: o tempo e as mudanças. In: NÓVOA, A (org.). Profissão professor. Porto: Porto Editora, 1995.

CONTRERAS, Jose. A autonomia de professores. São Paulo: Cortez, 2002. 
CORTELLA, Mario Sergio Cortella. A escola e o conhecimento: fundamentos epistemológicos e políticos. São Paulo: Cortez, 2000.

CORTESÃO, Luiza. Ser professor: um ofício em risco de extinção? São Paulo: Cortez,2002.

COSTA, Maria Costa Vorraber. Trabalho docente e profissionalismo: uma análise sobre gênero, classe e profissionalismo no trabalho de professoras e professores de classes populares. Porto Alegre: Sulina, 1995.

DAY, Christopher. Desenvolvimento Profissional de Professores: os desafios da aprendizagem permanente. Porto: Porto Editora, 1999.

DIAS, Márcia Hilsdorf. Professores da Escola Normal de São Paulo (1846-1890): a história não escrita. SP: FEUSP, 2002. (Dissertação de Mestrado).

DOMINGUES, Isaneide. O horário de trabalho coletivo e a (re)construção da profissionalidade docente. SP: FEUSP, 2004. (Dissertação de Mestrado).

DUARTE, Rosália. Entrevistas em pesquisas qualitativas. Educar, Curitiba, n.24, p. 213-225, 2004, Editora UFPR.

ENGUITA, Mariano Fernández. A ambigüidade da docência: entre o profissionalismo e a proletarização. In: Teoria \& Educação, Porto Alegre, n. 4, p. 41-61, 1991.

La profesión docente y la comunidad escolar: crónica de un desencuentro. Madrid: Ediciones Morata, 1995.

Educar em tempos incertos. Porto Alegre: Artmed, 2004.

FERREIRO, Emilia \& TEBEROSKY, Ana. Psicogênese da Língua Escrita. Porto Alegre: Artmed, 2006.

FIRMINO, Nicolau. Dicionário Latino-português. SP: Melhoramentos, 198-.

FREIRE, Paulo. Educação e participação comunitária. In: CASTELLS, M. et al (orgs.) Novas perspectivas criticas em educação. Porto Alegre: Artes Médicas, 1996a.

Pedagogia da autonomia: saberes necessários à prática educativa. SP: Paz e Terra, $1996 b$.

A Educação na Cidade. SP: Cortez, 2001. 
FUSARI, José Cerchi \& FRANCO, Alexandre de Paula. A formação contínua como um dos elementos organizadores do projeto político-pedagógico da escola. In: CASTRO, Tânia Maria Magalhães. Formação contínua de professores. Brasília, DF : MEC/SEED/TV ESCOLA, 2006.

GADOTTI, Moacir. A escola e o professor: Paulo Freire e a paixão de ensinar. SP: Publisher Brasil, 2007.

GHEDIN, Evandro. A reflexão sobre a prática cotidiana: caminho para a formação contínua e para o fortalecimento da escola enquanto espaço coletivo. In: CASTRO, Tânia Maria Magalhães. Formação contínua de professores. Brasília, DF : MEC/SEED/TV ESCOLA, 2006.

GIMENO SACRISTÁN, Jose. Consciência e ação sobre a prática como libertação profissional dos professores. In: NÓVOA, A. (org.). Profissão professor. Porto: Porto Editora, 1995.

GONÇALVES, José Alberto M. A carreira das professoras do ensino primário. In: NÓVOA, A. (org.) Vidas de Professores. Porto: Porto Editora, 2000.

GUIMARÃES, Valter Soares. Saberes profissionais: ponto de partida para formação contínua de professores. In: CASTRO, Tânia Maria Magalhães. Formação contínua de professores. Brasília, DF : MEC/SEED/TV ESCOLA, 2006.

GUSMÃO, Emery Marques. Memórias de quem ensina História: cultura e identidade docente. São Paulo: Editora UNESP, 2004.

HAGEMEYER, Regina Cely de Campos. Dilemas e desafios da função docente na sociedade atual: os sentidos da mudança. In: Educar em Revista, Curitiba, n.24, p. 6785, Editora UFPR, 2004.

HARGREAVES, Andy. Profesorado, cultura y postmodernidad: cambian los tiempos, cambia el profesorado. Madrid: Ediciones Morata, 1999.

HESSEN, Johannes. Teoria do Conhecimento. Coimbra: Armento Amado, 1980.

HUBERMAN, Michael. O ciclo de vida profissional dos professores. In: NÓVOA, António (org.). Vidas de professores. Porto: Porto Editora, 2000. pp. 31-61.

IMBERNÓN, Francisco. La formación y el desarrollo profesional del profesorado: hacia una nueva cultura profesional. Barcelona: Editorial Graó, 1998. 
JEFFREY, Debora Cristina. Representações de docentes sobre o Regime de Progressão Continuada: dilemas e possibilidades. São Paulo: FEUSP, 2006, (Tese de doutorado).

KNOBLAUCH, Adriane. A avaliação de alunos na implantação da proposta de ciclos de aprendizagem no município de Curitiba, á luz da cultura escolar. São Paulo: PUCSP, 2003. (Dissertação de Mestrado)

LANG, Alice Beatriz da Silva Gordo. História oral: muitas dúvidas, poucas certezas e uma proposta. In: MEIHY, José Carlos Sebe Bom (org.) (Re)introduzindo História Oral no Brasil. São Paulo: Xamã, 1996.

LIBÃNEO, José Carlos. Organização e gestão da escola: teoria e prática. Goiânia: Alternativa, 2001.

LEITE, Sérgio Antonio da Silva e COLOMBO, Fabiana Aurora. A voz do sujeito como fonte primária na pesquisa qualitativa: a autoscopia e as entrevistas recorrentes. In: PIMENTA, Selma Garrido; GHEDIN, Evandro; FRANCO, Maria Amélia Santoro Franco (Orgs.). Pesquisa em educação: alternativas investigativas com objetos complexos. SP: Edições Loyola, 2006.

LIMA, Maria Socorro Lucena. A formação contínua do professor nos caminhos e descaminhos do desenvolvimento profissional. São Paulo: FEUSP, 2001. (Tese de Doutorado).

MACHADO, Nilson José. Epistemologia e Didática: as concepções de conhecimento e inteligência e a prática docente. Sp: Cortez, 1996.

MARCELO GARCIA, Carlos. Formación del profesorado para el cambio educativo. Barcelona: PPU, 1994.

A formação de professores: novas perspectivas baseadas na investigação sobre o pensamento do professor. In: NÓVOA, António (coord.). Os professores e a sua formação. Lisboa: Publicações Dom Quixote/ Instituto de Inovação Educacional, 1995. MARCÍLIO, Maria Luiza. História da escola em São Paulo e no Brasil. São Paulo: Imprensa Oficial do Estado de São Paulo: Instituto Fernand Braudel, 2005.

MARCUSCHI, Luiz Antônio. Da fala para a escrita: atividades de retextualização. São Paulo: Cortez, 2001. 
MEIHY, José Carlos Sebe Bom. Manual de História Oral. SP: Edições Loyola, 2005. MOITA, Maria da Conceição. Percursos de formação e de trans-formação. In: NÓVOA, A. (org.) Vidas de Professores. Porto: Porto Editora, 2000.

MOSER, PAUL K. A teoria do conhecimento: uma introdução temática. SP: Martins Fontes, 2004.

NEIRA, Marcos Garcia. Repensando a prática pedagógica. São Paulo: Editora Mackenzie, 2005.

NÓVOA, António. Do mestre-escola ao professor do ensino primário: subsídios para a história da profissão docente em Portugal (séculos XVI-XX). Lisboa: Universidade Técnica de Lisboa, 1986.

Para o estudo sócio-histórico da gênese e desenvolvimento da profissão docente. In: Teoria \& Educação, n. ${ }^{\circ}$ 4, 1991. Porto Alegre: Pannonica Editora Ltda. Formação de professores e profissão docente. In: NÓVOA, António (coord.). Os professores e a sua formação. Lisboa: Publicações Dom Quixote/ Instituto de Inovação Educacional, 1995a.

. (org.). Profissão Professor. Porto: Porto Editora, 1995b.

Relação escola-sociedade: novas respostas para um velho problema. In: SERBINO, Raquel Volpato et al. (orgs.). Formação de professores. São Paulo: Fundação Editora da UNESP, 1998.

Os professores na virada do milênio: do excesso dos discursos à pobreza das práticas. Educ. Pesqui., São Paulo, v. 25, n. 1,1999 . Disponível em: $<$ http://www.scielo.br/scielo.php?script=sci_arttext\&pid=S151797021999000100002\&lng=pt\&nrm=iso >. Acesso em: 07 Ago 2006.

. Vidas de professores. Porto: Porto Editora, 2000.

PAPI, Silmara de Oliveira Gomes. Professores: formação e profissionalização. Araraquara, SP: Junqueira\&Marin, 2005.

PAQUAY, Léopold. Competências profissionais privilegiadas nos estágios e na videoformação. In: PAQUAY, Léopold, et. al.. Formando professores profissionais: Quais estratégias? Quais competências? Porto Alegre: Artmed, 2001. 
PASSOS, Mauro. Historiando embates e conquistas da profissão docente em Minas Gerais (1977-2004). In: PEIXOTO, Ana Maria Casassanta \& PASSOS, Mauro (orgs.). A escola e seus atores - educação e profissão docente. Belo Horizonte: Autêntica, 2005. p. 29-52.

PÉREZ GÓMEZ, Angel I. A Cultura escolar na sociedade neoliberal. Porto Alegre: Artmed, 2001.

PERRENOUD, Philippe. Profissionalização do professor e desenvolvimento de ciclos de aprendizagem. In: Cadernos de Pesquisa. São Paulo, n. 108, p. 7-26, nov. 1999.

PESQUISA NACIONAL UNESCO. O perfil dos professores brasileiros: o que fazem, o que pensam, o que almejam... São Paulo: Moderna, 2004.

PIAGET, Jean. O nascimento da inteligência na criança. Rio de Janeiro: Zahar, 1978. A construção do real na criança. Rio de Janeiro: Zahar, 1979.

RIOS, Terezinha Azerêdo. Compreender e Ensinar: por uma docência da melhor qualidade. São Paulo: Cortez, 2001.

SÃO PAUlO. SECRETARIA MUNICIPAL DE EDUCAÇÃO. Programa Ler e Escrever - Prioridade na Escola Municipal. São Paulo, 2005. Disponível em: http://portaleducacao.prefeitura.sp.gov.br/. Acessado em dezembro de 2007.

SARMENTO, Manuel Jacinto. A vez e a voz dos professores. Porto: Porto Editora, 1994.

SCHON, Donald. Formar professores como profissionais reflexivos. In: NÓVOA, António (Coord.). Os professores e a sua formação. Lisboa: Publicações Dom Quixote/ Instituto de Inovação Educacional, 1995.

SILVA, Maria Celeste Marques da. O primeiro ano de docência: o choque com a realidade. In: ESTRELA, Maria Teresa (org.). Viver e construir a profissão docente. Porto: Porto Editora, 1997.

SOUZA, Rosa Fátima de. Templos de civilização: a implantação da escola primária graduada no Estado de São Paulo: 1890-1910. São Paulo: Fundação Editora da UNESP, 1998. 
SOUZA, Vera Maria de. Formação em serviço de professores da Secretaria Municipal de Educação de São Paulo: 1956-2004. São Paulo: FEUSP, 2005. (Dissertação de mestrado).

TANURI, Leonor Maria. Contribuição para o estudo da escola normal brasileira. SP: FFCL, 1969. (dissertação de mestrado).

O ensino normal no estado de São Paulo - 1830-1930. São Paulo: Faculdade de Educação da USP, 1979. (tese de doutorado).

TARDIF, Maurice e LESSARD, Claude. O trabalho docente: elementos para uma teoria da docência como profissão de interações humanas. Petrópolis: Vozes, 2005.

TARDIF, Maurice. Saberes Docentes e formação profissional. Petrópolis: Vozes, 2005.

THOMPSON, Paul. A voz do passado: história oral. Rio de Janeiro: Paz e Terra, 1998.

TRIVIÑOS, Augusto N. S. Introdução à pesquisa em ciências sociais: a pesquisa qualitativa em educação. São Paulo: Atlas, 1987.

VYGOTSKY, Lev Semenovich. Formação social da mente: o desenvolvimento dos processos psicológicos superiores. São Paulo: Martins Fontes, 2000.

WALLON, H. Origens do pensamento na criança. São Paulo: Manole, 1989.

A evolução psicológica da criança. Lisboa: Edições 70, 2005.

WEY, Vera Lucia. Progressão Continuada da Aprendizagem: o que falta dizer sobre sua implantação. In: SEE Progressão Continuada: Compromisso com a aprendizagem. Fórum de Debates, Anais 2002. São Paulo, SEE, 2002.

XAVIER, Maria Luisa M. Escola Cidadã estrutura por ciclos de formação: estruturação, implantação e desdobramentos do projeto. In: MOLL, J. (org.). Ciclos na Escola, Tempos na Vida - criando possibilidades. Porto Alegre: Artmed, 2004. 
$\underline{\text { ANEXOS }}$ 


\section{ANEXO 1 - Roteiro para entrevista com professoras (segundo semestre de 2006)}

- Fale um pouco de você mesma, como você descreveria sua vida profissional? (seu processo de escolha profissional, tempo no magistério, sua formação);

- O que você acredita ser o papel do professor na escola? Qual seu campo de atuação (psicológico, pedagógico, sociológico, vários, intelectual, etc.)?

- Há limites da atuação docente, da ação do professor?

- Como você constrói, avalia e implementa sua ação pedagógica no dia-a-dia da escola? Foi assim desde o começo da carreira?

- Você se lembra do seu primeiro dia de aula como professora? Você é a mesma professora desde aquele tempo? (Mudou alguma coisa de lá para cá)

- Como você selecionava o conteúdo no início da sua carreira? E hoje?

- Descreva como você prepara/planeja uma aula? - Você consegue seguir a risca seu planejamento?

- Que materiais utiliza para suas aulas?

- Atualmente você leciona para qual ano? Sempre lecionou para essa faixa etária?

- Você já passou por algumas reformas na educação? Como você sentiu estas reformas? Mudou o seu jeito de atuar na escola?

- Sobre os ciclos, que repercussões o ensino organizado em ciclos têm trazido para a postura dos estudantes? E para a postura dos professores?

- Que mudanças a proposta de ciclos têm trazido para sua prática? Essas mudanças têm sido incorporadas ao seu cotidiano?

- Comente suas impressões sobre o aluno que temos hoje e quais suas preocupações ao desenvolver seu ensino e sua formação?

- Como era o aluno de dez anos atrás? 
- Você participa ou participou de algum curso de formação continuada? E de eventos em educação?

- Como aproveita seu tempo livre? Quais seus hobbies?

- Qual é a função do professor na escola pública do século XXI? 
ANEXO 2 - Roteiro para Entrevista Recorrente (primeiro semestre de 2007)

- Fale-me sobre sua relação com o conhecimento;

- Como você lida com sua autonomia. 